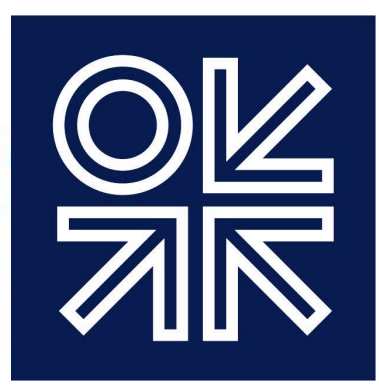

THE OXFORD

INSTITUTE

FOR ENERGY

STUDIES

January 2019

\title{
LNG Supply Chains and the Development of LNG as a Shipping Fuel in Northern Europe
}

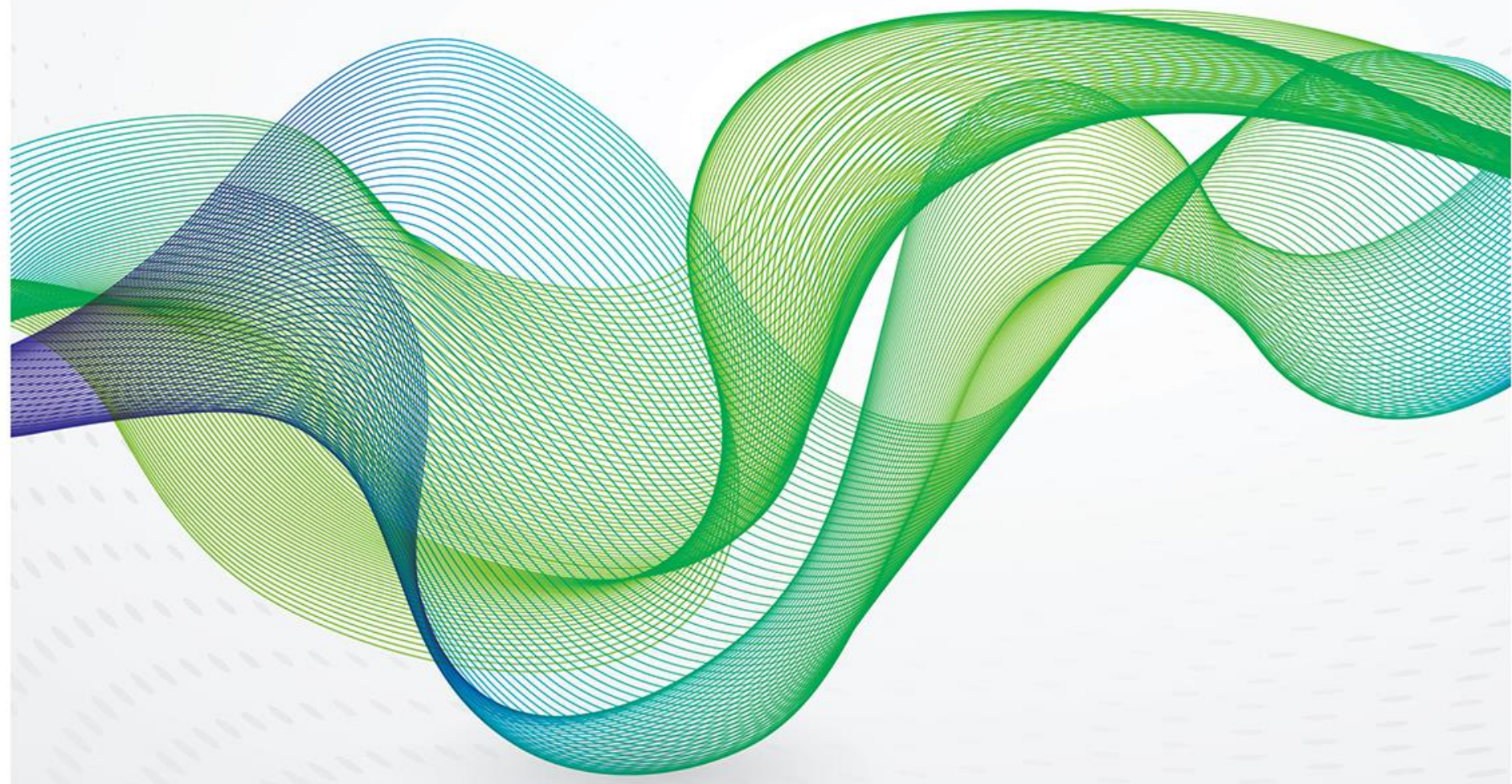


The contents of this paper are the authors' sole responsibility. They do not necessarily represent the views of the Oxford Institute for Energy Studies or any of its members.

Copyright $\odot 2019$

Oxford Institute for Energy Studies

(Registered Charity, No. 286084)

This publication may be reproduced in part for educational or non-profit purposes without special permission from the copyright holder, provided acknowledgment of the source is made. No use of this publication may be made for resale or for any other commercial purpose whatsoever without prior permission in writing from the Oxford Institute for Energy Studies.

ISBN: 978-1-78467-126-6

DOI: https://doi.org/10.26889/9781784671266 

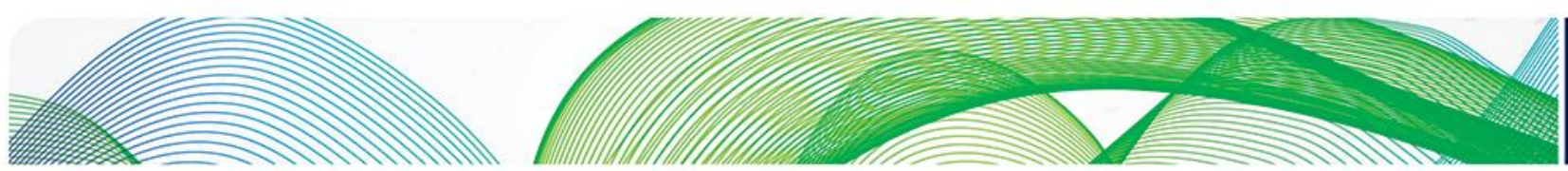

\section{임}

\section{Acknowledgments}

I would like to offer my thanks to my colleagues here at OIES for their support during the writing of this paper. Specifically, to Chris Le Fevre, David Ledesma, and James Henderson for their feedback on the paper itself, to Catherine Gaunt for the copy editing, and to Kate Teasdale for her valuable administrative support. The responsibility for the conclusions reached as a result of this research, and any errors in this paper, is entirely mine.

This paper was updated in February 2019. 

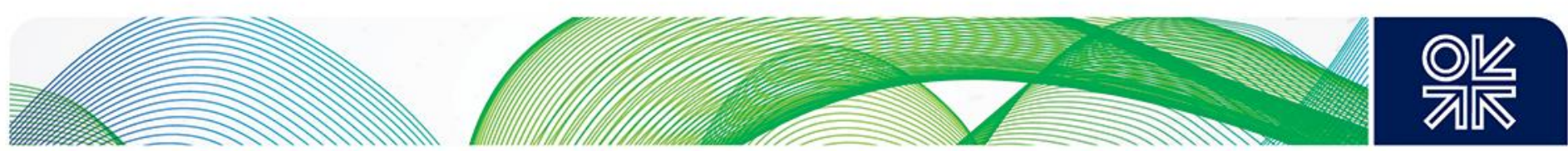

\section{Preface}

In his 2018 working paper for OIES entitled "A review of demand prospects for LNG as a marine transport fuel" (NG133) Chris Le Fevre provided an overview of the outlook for the growth of LNG demand in its most promising transport sector. He concluded that the imminent application of more stringent emissions rules by the International Maritime Organisation provided some hope that gas could displace fuel oil as a power source for specific vessels, although he concluded that the change would probably be more gradual than many were hoping.

In addition, it is clear that the growth will be catalysed by demand for LNG in ships that operate within the Emissions Control Areas that have been defined by the IMO, and this paper by Jack Sharples focuses on one of those areas, covering the Baltic and North Seas, as a case study for the development of an LNG value chain in the marine sector. The paper examines how environmental regulations have initiated change, which in turn has incentivised the construction of the infrastructure that is vital to LNG as a bunker fuel. The use of government subsidies has also been important, but the paper shows that vessel owners are gradually becoming more willing to shift towards $L N G$ as a fuel for their fleets, especially as ships are replaced and new vessels are added. Furthermore, the incentives to invest across the $L N G$ value chain are increasing as a virtuous cycle of investment and consumption emerges.

The importance of this case study is that it may provide an indicator for the development of LNG as a marine fuel in other areas, and the author makes some significant comparisons with other ECAs and regions of the world where gas is already helping to solve issues of air quality. As a result, this working paper is an important addition to the growing body of work being published by OIES on the role which gas can play in a world where decarbonisation and improvements in air quality are becoming key driving forces in the development of the global energy system.

\section{James Henderson}

Director, Natural Gas Programme

Oxford Institute for Energy Studies 


\section{Contents}

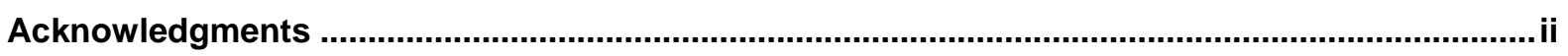

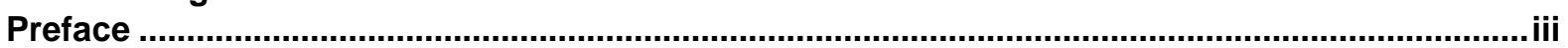

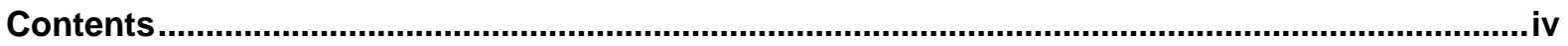

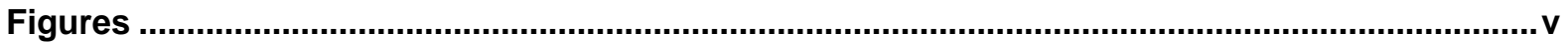

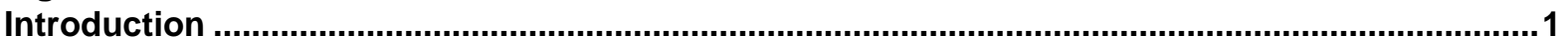

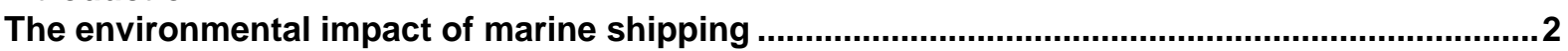

Context: Tightening regulation of pollution from marine transportation .....................................2

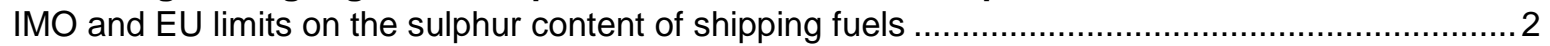

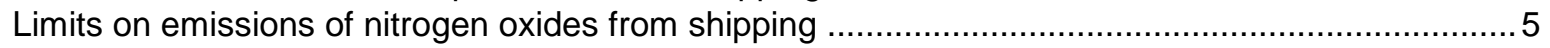

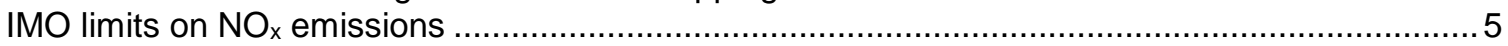

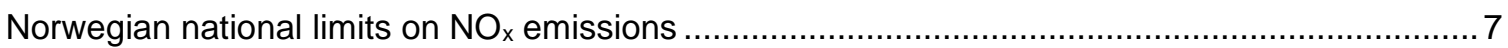

Monitoring, regulating, and reducing $\mathrm{CO}_{2}$ emissions from shipping .......................................

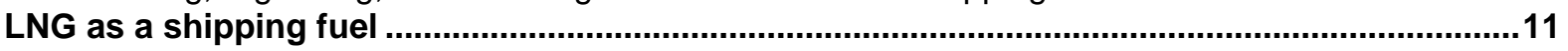

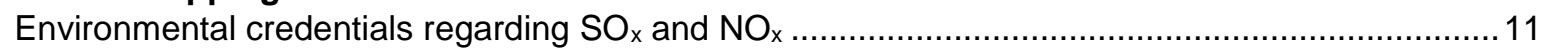

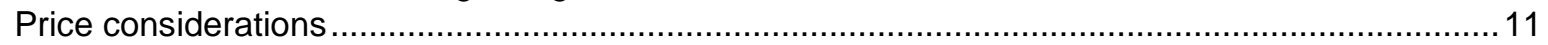

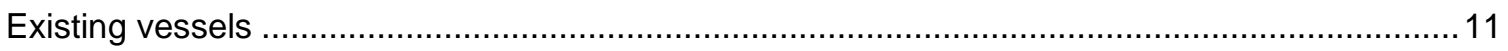

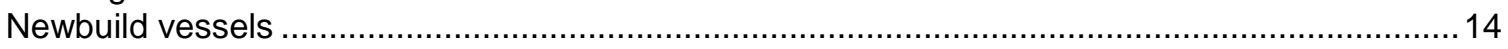

Where does this leave the economic case for LNG? ......................................................... 15

LNG supplies in the North Sea and Baltic Sea region: Sources of LNG for bunkering ..............15

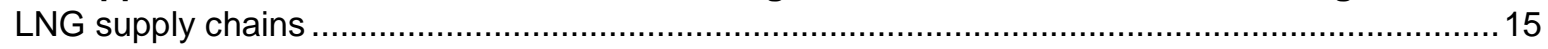

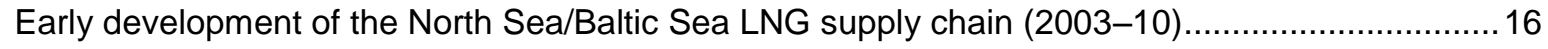

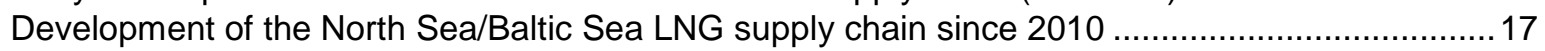

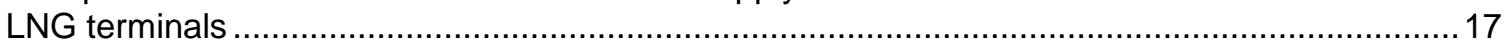

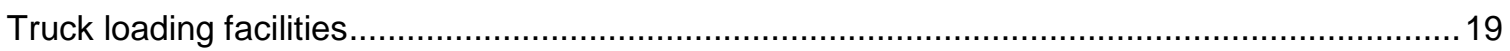

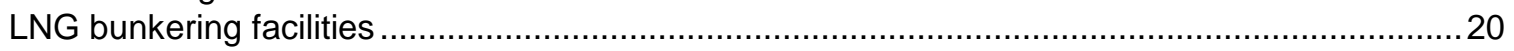

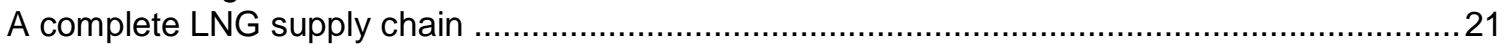

Market development: The regional LNG-propelled fleet ..............................................................23

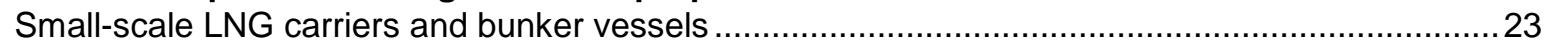

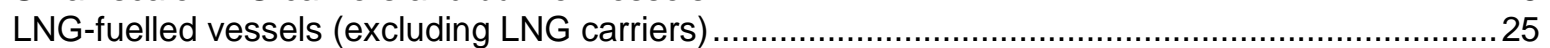

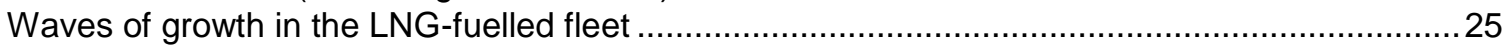

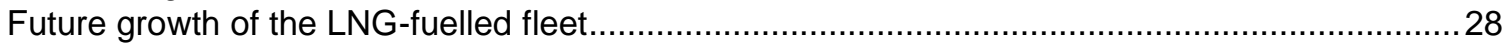

The regional non-LNG fuelled fleet and prospects for bunker fuel demand ................................... 30

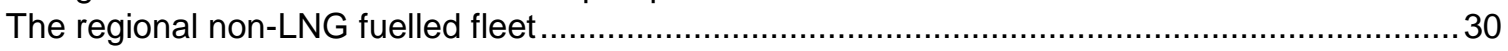

Challenges in measuring current regional bunker fuel demand ................................................. 32

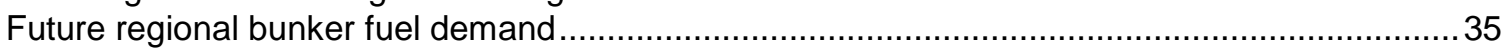

Significant actors in the North Sea/Baltic Sea LNG supply chain ...............................................36

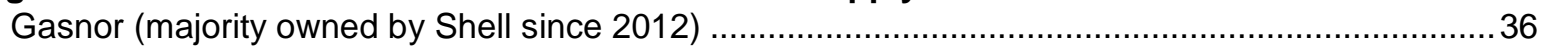

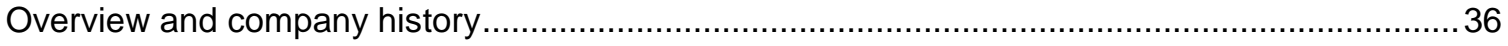

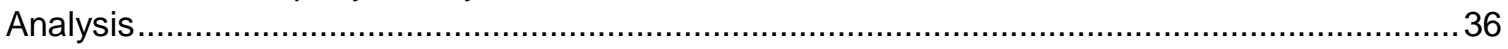

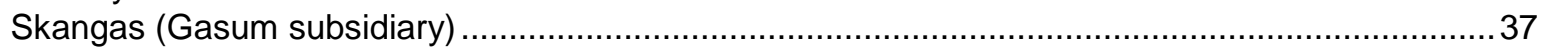

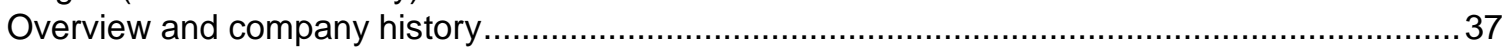

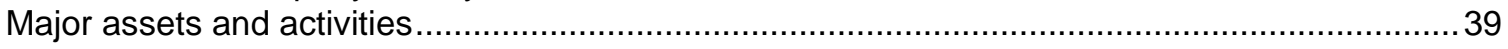

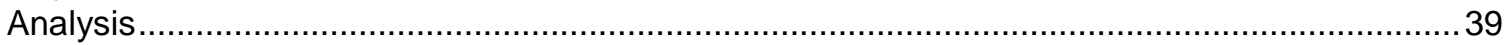

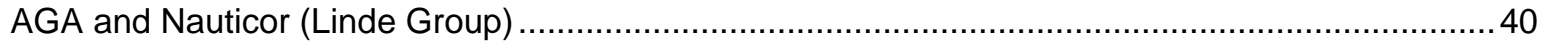

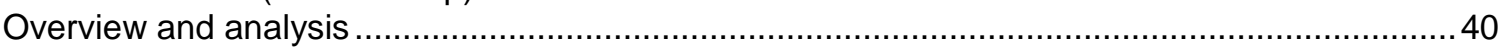

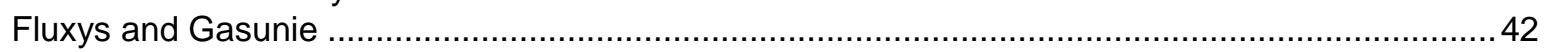

Comparing the business strategies of different bunker fuel suppliers ........................................ 43

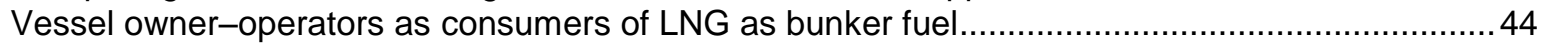

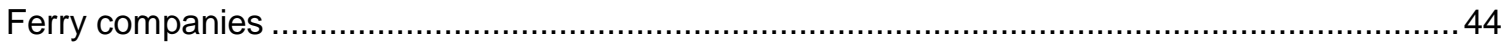



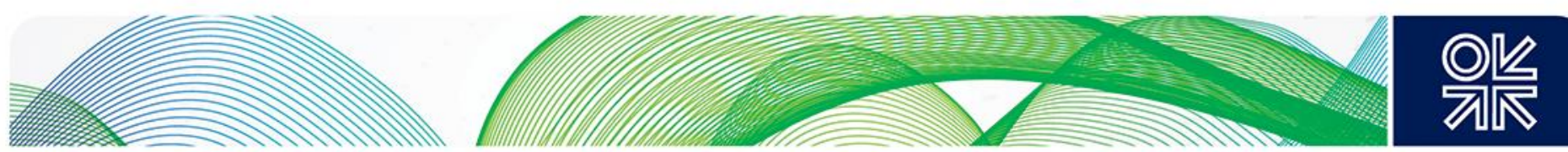

Shipping companies .45

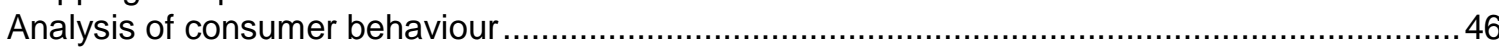

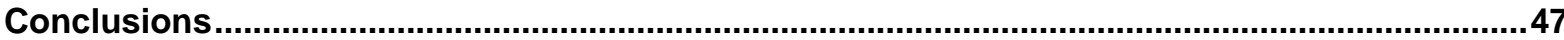

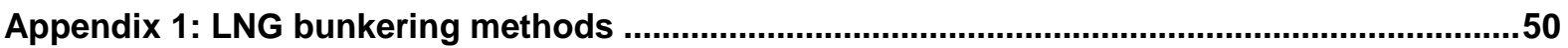

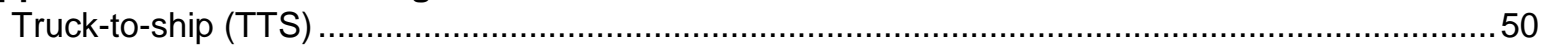

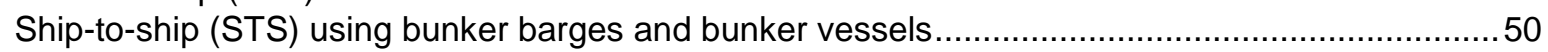

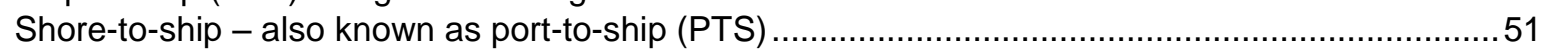

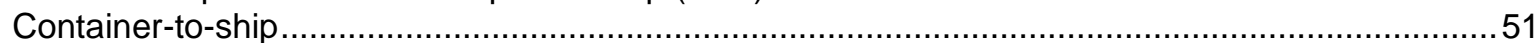

Appendix 2: Availability of LNG services in the North Sea/Baltic Sea region .............................52

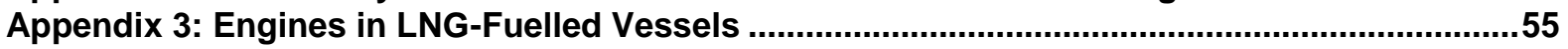

\section{Figures}

Figure 1: Permitted sulphur content of shipping exhaust gases under IMO/EU regulations .................4

Figure 2: Current IMO limits on $\mathrm{NO}_{x}$ emissions by ship construction date and engine speed ..............6

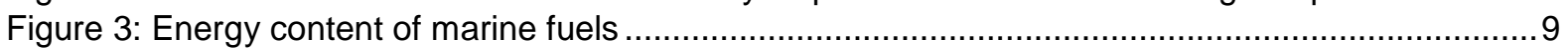

Figure 4: Bunker fuel prices in NW Europe (US\$ per tonne) ...................................................... 12

Figure 5: LNG import and export terminals in the North Sea/Baltic Sea ECAs ................................18

Figure 6: Schematic representation of the different LNG bunkering practices ...................................20

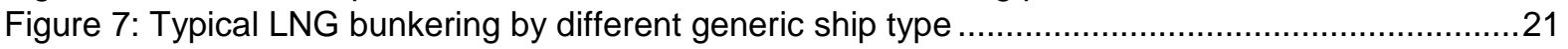

Figure 8: Existing LNG bunkering facilities in the North Sea/Baltic Sea ECAs ................................22

Figure 9: Global fleet of LNG-fuelled vessels by location (number of vessels in operation) ................26

Figure 10: Global LNG-fuelled fleet in operation by vessel type and location (January 2019) ............27

Figure 11: Vessels in operation and on order by type in the North Sea/Baltic Sea region, including Norway (January 2019)

Figure 12: Global LNG-fuelled fleet on order by vessel type and location ........................................30

Figure 13: Vessels by type operating in the North Sea and Baltic Sea (UNCTAD and Marine Traffic statistics)

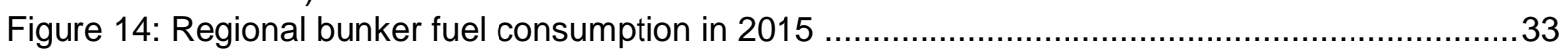

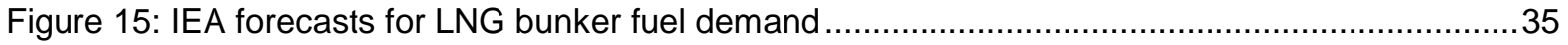



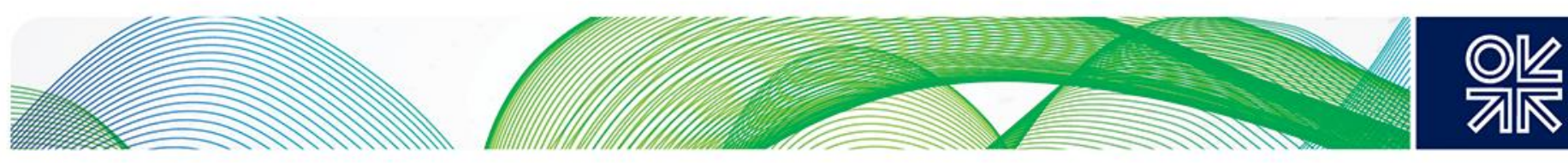

\section{Introduction}

In a market dominated by heavy fuel oil (HFO) since the mid-twentieth century, increasingly restrictive regional environmental regulations are prompting adaptation by the shipping sector, and forcing ship owners and operators to reconsider their fuel choices. In particular, between 2006 and 2015, several rounds of increasingly stringent environmental regulations regulating sulphur oxide $\left(\mathrm{SO}_{\mathrm{x}}\right)$ emissions were applied in the Emissions Control Areas (ECAs) of Northern Europe and North America, under the auspices of the International Maritime Organization (IMO). Similar, albeit less stringent, IMO restrictions of $\mathrm{SO}_{\mathrm{x}}$ emissions were established at a global level in 2005 and tightened in 2012.

In a highly significant development, substantially more stringent global regulations of $\mathrm{SO}_{\mathrm{x}}$ emissions will enter into force in January 2020. One of the options for ship owners/operators is to switch to LNG as a shipping fuel, either by retrofitting their existing vessels, or by purchasing new, purpose-built, LNGfuelled vessels. Given the importance of the changes that could take place after 2020, the process of adaptation in the ECAs since 2010 (and especially since 2015) provides insights into potential paths of development at a global level post-2020.

Specifically, this paper analyses the extent to which LNG has been taken up as a marine shipping fuel in the North Sea/Baltic Sea ECAs. LNG is a commercially and environmentally feasible alternative to oil-based shipping fuels because it contains virtually no $\mathrm{SO}_{x}$, and so would be compliant with the new restrictions without any further investment in emissions abatement systems. LNG also offers a means of reducing nitrogen oxide $\left(\mathrm{NO}_{\mathrm{x}}\right)$ emissions, which have been capped for newbuild vessels at global and regional levels, with a further tightening of $\mathrm{NO}_{x}$ emissions regulations due to take effect in Northern Europe from 2021. However, the caveat remains that LNG offers limited potential for reducing carbon dioxide $\left(\mathrm{CO}_{2}\right)$ emissions from shipping. In conducting this analysis, three key conclusions are drawn:

Firstly, by demonstrating that changes in regional environmental regulations have been a crucial catalyst for the uptake of LNG as a marine shipping fuel in Northern Europe, this paper concludes that changes in global environmental regulations could incentivise the uptake of $L N G$ as a marine shipping fuel at a global level, in regions beyond the current ECAs.

Secondly, by demonstrating that the development of the infrastructure for bunkering vessels with LNG can be built onto existing regional LNG infrastructure in a relatively short period of time ('building the last mile'), and that such development provides significant added value relative to the relatively modest additional capital outlay, this paper concludes that the development of LNG bunkering infrastructure is most likely in regions that already have substantial LNG infrastructure.

Thirdly, this paper demonstrates that ship owners are willing to invest in new LNG-fuelled vessels, but appear to be less enthusiastic about retrofitting existing vessels with LNG propulsion systems. Given that vessels have lifespans of several decades, and that the size of the LNG-fuelled fleet is growing year-on-year, this leads to the conclusion that LNG is being 'phased into' the marine shipping sector. Consequently, demand for LNG as a shipping fuel is likely to rise at a steady pace, rather than in a sudden 'big bang'. This should allow time for the development of the necessary additional infrastructure, and prevent marine fuel demand from acting as a source of volatility on the global LNG market.

In short, this paper demonstrates the extent to which an LNG supply chain has developed in the North Sea and Baltic Sea regions, where environmental regulations prompted demand for LNG as a marine shipping fuel. The previously existing regional LNG market infrastructure provided a base upon which the 'last mile' of LNG bunkering infrastructure was developed, while the substantial increase in the number of LNG-fuelled vessels operating in that region demonstrated that demand for LNG as a shipping fuel has indeed increased to a level that provides commercial opportunities for bunker fuel suppliers. 

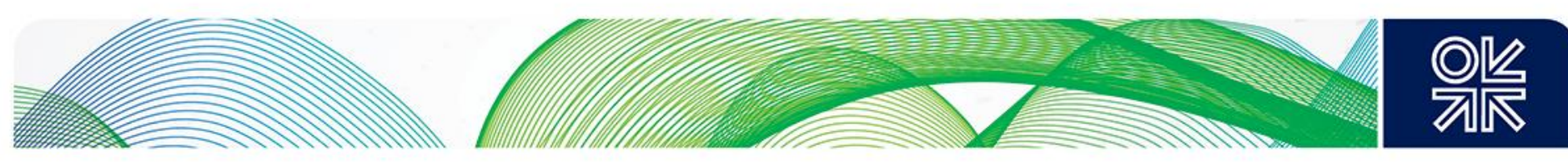

When applied to regions beyond the North Sea/Baltic Sea ECAs, the lessons of this case study suggest that, in areas with sufficient pre-existing LNG infrastructure, the introduction of more stringent environmental regulations can solve the 'chicken and egg' dilemma of energy companies not wishing to invest in LNG bunkering infrastructure until there is substantial demand for LNG as a marine fuel, while ship owners and operators remain reluctant to invest in new LNG-fuelled vessels (or retrofit existing vessels to run on LNG) until there is substantial bunkering infrastructure to meet their bunker fuel needs. With more stringent environmental regulations due to enter into force at a global level in January 2020, this North Sea/Baltic Sea case study demonstrates that LNG does have a viable future as a shipping fuel at a global level, albeit at a steady, rather than a spectacular, rate of growth.

\section{The environmental impact of marine shipping}

Transportation is a major source of $\mathrm{CO}_{2}$ emissions, and of air pollution that impacts upon public health - specifically emissions of sulphur oxides $\left(\mathrm{SO}_{\mathrm{x}}\right)$, nitrogen oxides $\left(\mathrm{NO}_{\mathrm{x}}\right)$, and primary particulate matter (PM). In 2015, global $\mathrm{CO}_{2}$ emissions from fuel combustion reached 32.3 billion tonnes, of which transportation accounted for 7.7 bn tonnes. This includes emissions from road transportation (5.8 bn tonnes), shipping (657 million tonnes), and aviation (530 m tonnes). ${ }^{1}$ Road transportation is also the primary contributor to global transport-sector emissions of $\mathrm{NO}_{x}$ (58 per cent) and PM (73 per cent). ${ }^{2}$

While road transportation accounts for the majority of global transport-sector $\mathrm{CO}_{2}, \mathrm{NO}_{x}$, and $\mathrm{PM}$ emissions, shipping accounts for around 90 per cent of global transport-sector $\mathrm{SO}_{x}$ emissions, and tends to be the largest source of local $\mathrm{NO}_{x}$ and $\mathrm{SO}_{x}$ emissions around major shipping lanes and port cities. Shipping is therefore a significant factor in local air quality in specific geographical locations. This is because shipping fuels tend to be of the cheaper, less refined, and more polluting variety. As noted by the IEA:

The sulphur content of maritime bunker fuel oil can be as high as 3.5 per cent, while the oil products used in road transport can contain as little as 10 ppm (parts per million). ${ }^{3,4}$

In other words, heavy fuel oil for bunkering may contain up to 3,500 times as much sulphur as oil products used as road transport fuel. It is not simply the volume of fuel consumed in the shipping industry, but the type of fuel consumed that has a distinct bearing on the air pollution generated by fuel combustion for shipping.

Given the prominent role of shipping in global transport-sector $\mathrm{SO}_{\mathrm{x}}$ emissions and in local $\mathrm{SO}_{\mathrm{x}}$ and $\mathrm{NO}_{\mathrm{x}}$ emissions from all sectors, it is this particular aspect of shipping-sector pollution that has been targeted by international and national environmental legislation, causing commercial actors to adapt their activities and opening opportunities for the use of LNG as a shipping fuel.

\section{Context: Tightening regulation of pollution from marine transportation}

\section{IMO and EU limits on the sulphur content of shipping fuels}

In 1973, the United Nations International Maritime Organization (IMO) established the International Convention for the Prevention of Pollution from Ships (MARPOL), later amended by protocols in 1978 and 1997. ${ }^{5}$ The 1997 protocol added 'Annex VI: The Prevention of Air Pollution from Ships' to the legally

\footnotetext{
$\mathrm{CO}_{2}$ emissions from fuel combustion, Paris: IEA, 2017. See pages II.16, II.19, and II.22.

${ }^{2}$ Energy and air pollution: World energy outlook special report, Paris: IEA, 2016. See page 49.

${ }^{3}$ Energy and air pollution: World energy outlook special report, IEA, 2016. See page 53-54.

${ }^{4} 10 \mathrm{ppm}$ (parts per million) equates to 0.001 per cent.

${ }^{5}$ List of IMO Conventions, IMO, 2018. www.imo.org/en/About/Conventions/ListOfConventions/Pages/Default.aspx. Sourced on 8 March 2018.
} 

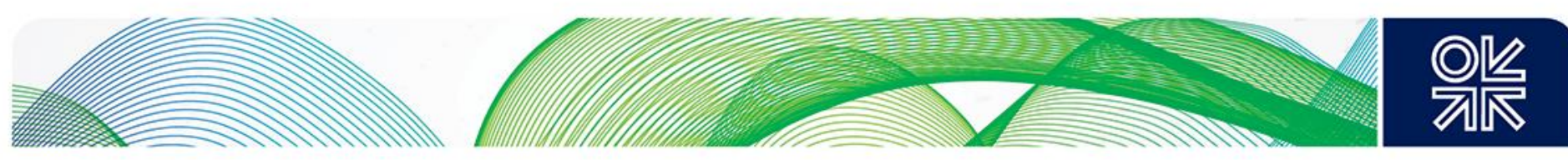

binding MARPOL convention, and established a global cap on $\mathrm{SO}_{\mathrm{x}}$ emissions from fuel combustion in shipping at 4.5 per cent mass $/$ mass. ${ }^{6}$ That protocol entered into force on the $19^{\text {th }}$ of May $2005 .{ }^{7} \mathrm{~A}$ revised version of Annex VI was adopted at the $58^{\text {th }}$ meeting of the IMO Marine Environment Protection Committee (MEPC 58) in October 2008 and entered into force on the $1^{\text {st }}$ of July 2010, reducing the global cap to 3.5 per cent mass/mass, from the $1^{\text {st }}$ of January $2012.8,9$

In designated Emission Control Areas (ECAs), the regulation of $\mathrm{SO}_{\mathrm{x}}$ emissions is more stringent. There are currently four ECAs regulated by the IMO: ${ }^{10}$

- the Baltic Sea,

- the North Sea (the borders of the Baltic Sea and North Sea ECAs are illustrated in Figure 5),

- the Pacific and Atlantic coastal areas of North America (the USA and Canada), and

- the Caribbean Seas of the USA.

Changes in the permitted sulphur content of shipping fuels in the four ECAs are illustrated in Figure 1. $\mathrm{SO}_{\mathrm{x}}$ emissions in the Baltic and North Sea ECAs were capped at 1.5 per cent mass/mass from the $19^{\text {th }}$ of May 2006 and 22 nd of November 2007 respectively, as a result of the 1997 Protocol entering into force in May 2005. ${ }^{11}$ Then, from the $1^{\text {st }}$ of July 2010, the cap on SOx emissions in the Baltic and North Sea ECAs was reduced to 1.0 per cent mass/mass, as a result of the revision adopted in October 2008. These regulations took effect with regard to the North American ECA on the $1^{\text {st }}$ of August 2012, and with regard to the US Caribbean Seas on the $1^{\text {st }}$ of January 2014, with the relevant regulations having been adopted in 2010 and 2011 respectively. ${ }^{12}$ Then, from the $1^{\text {st }}$ of January 2015, the SOx emissions cap in all ECAs was reduced to 0.1 per cent mass/mass.

Finally, at MEPC 70 in October 2016, it was agreed that the global cap on $\mathrm{SO}_{x}$ emissions (those outside the ECAs) will be reduced from 3.5 per cent to 0.5 per cent from the $1^{\text {st }}$ of January $2020 .{ }^{13}$

In this context, the Baltic Sea and North Sea ECAs should be seen as 'test cases' for the potential impact of the tightening of global regulations on shipping-sector $\mathrm{SO}_{x}$ emissions. Specifically, an analysis of the development of LNG as a shipping fuel in the North Sea and Baltic Sea regions highlights the factors that could contribute to the development of LNG as a shipping fuel elsewhere post-2020, under the new, stricter, emissions regulations.

\footnotetext{
6 'Protocol of 1997 to amend the International Convention for the Prevention of Pollution from Ships of 2 November 1973, as modified by the Protocol of 17 February 1978', Admiralty and Maritime Law Guide, IMO, 26 September, 1997. www.admiraltylawguide.com/conven/protomarpol1997.html. Sourced on 11 July 2018. See Regulation 14.

7 'Annex VI of MARPOL 73/78 - Regulations for the Prevention of Air Pollution from Ships', Gard News, 1 November 2004. www.gard.no/web/updates/content/53059/annex-vi-of-marpol-7378-regulations-for-the-prevention-of-air-pollution-from-ships. Sourced on 11 July 2018.

${ }^{8}$ Prevention of Air Pollution from Ships, IMO, 2018.

www.imo.org/en/OurWork/environment/pollutionprevention/airpollution/pages/air-pollution.aspx. Sourced on 8 March 2018. See

Regulation 14 of Annex VI: 'SOx and Particulate Matter Emission Control'.

${ }^{9}$ Sulphur oxides (SOx) and Particulate Matter (PM) - Regulation 14, IMO, 2018.

www.imo.org/en/OurWork/Environment/PollutionPrevention/AirPollution/Pages/Sulphur-oxides-(SOx)-\%E2\%80\%93-

Regulation-14.aspx. Sourced on 22 August 2018.

${ }^{10}$ Emission Control Areas (ECAs) designated under regulation 13 of MARPOL Annex VI (NOx emission control), IMO, 2018. www.imo.org/en/OurWork/Environment/PollutionPrevention/AirPollution/Pages/Emission-Control-Areas-(ECAs)-designatedunder-regulation-13-of-MARPOL-Annex-VI-(NOx-emission-control).aspx. Sourced on 8 March 2018.

${ }^{11}$ Special Areas under MARPOL, IMO, 2018

www.imo.org/en/OurWork/Environment/SpecialAreasUnderMARPOL/Pages/Default.aspx. Sourced on 11 July 2018.

${ }_{12}$ IMO, 2018. Special Areas under MARPOL (op. cit.)

${ }^{13}$ IMO, 2018. Sulphur oxides (SOx) and Particulate Matter (PM) - Regulation 14 (op. cit.)
} 

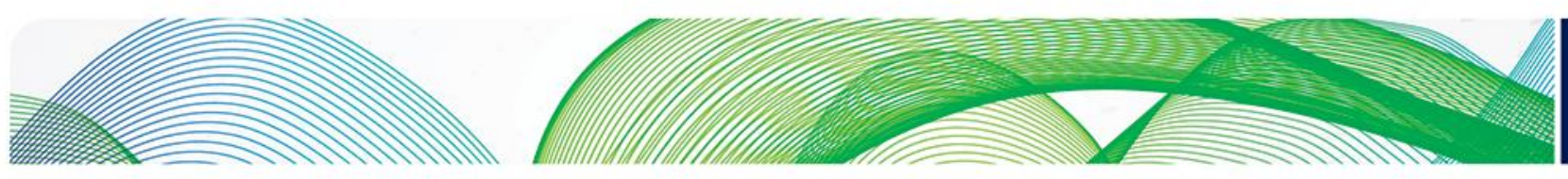

Figure 1: Permitted sulphur content of shipping exhaust gases under IMO/EU regulations

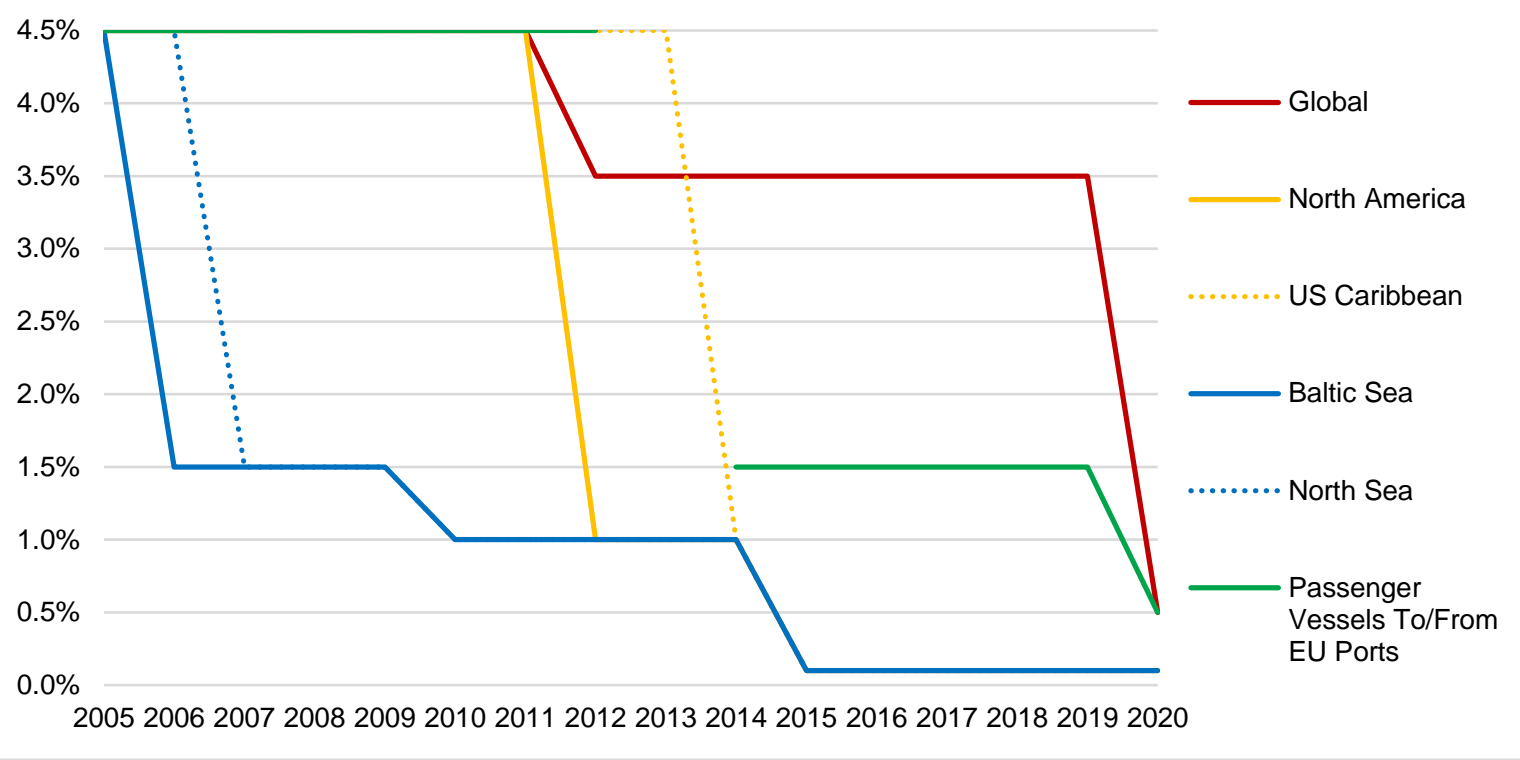

Source: Graph created by author, using data from IMO and EU.

In addition to the regulations governed by the IMO, the European Union has its own regulations regarding the sulphur content of marine fuels. Since 2016, EU Directive 2016/802 ${ }^{14}$ has stipulated that marine fuels used in EU territory should have a sulphur content no greater than 3.5 per cent, unless certain specified sulphur emissions abatement methods are used (Article 5). This limit applies until the $1^{\text {st }}$ of January 2020, at which point the limit will fall to 0.5 per cent (Article 6). In the IMO SO ECAs, the limit was 1.0 per cent until the $31^{\text {st }}$ of December 2014 , and has been 0.1 per cent since the $1^{\text {st }}$ of January 2015 (Article 6). Thus, EU regulations are in line with IMO regulations.

In a measure more stringent than IMO regulations, Article 6(5) of EU Directive 2016/802 states that passenger vessels on regular services to and from EU ports will be limited to consuming fuel with a maximum sulphur content of 1.5 per cent when in EU territorial waters and exclusive economic zones, until the $1^{\text {st }}$ of January 2020. This applies to passenger ships operating to and from EU ports located outside the North Sea and Baltic Sea ECAs. Article 7 of the same Directive also places a 0.1 per cent sulphur cap on fuels consumed by ships when at berth in EU ports for more than two hours, unless all engines are switched off and the ship uses shore-side electricity to run its power systems. Finally, Article $7(3)$ also forbids the sale on EU territory of marine gasoil with a sulphur content greater than 0.1 per cent. These restrictions were originally introduced in November 2012, for transposition into EU member state law by June $2014 .{ }^{15}$

Therefore, from now until January 2020, ships in EU waters outside the North Sea and Baltic Sea ECAs are limited to consuming fuels with maximum sulphur content of 3.5 per cent, apart from passenger ferries, which are limited to 1.5 per cent. Then, from 2020, the global cap of 0.5 per cent will apply. In the North Sea and Baltic Sea ECAs, the 0.1 per cent sulphur limit has been in place since 2015.

\footnotetext{
${ }^{14}$ Directive (EU) 2016/802 of the European Parliament and of the Council of 11 May 2016 relating to a reduction in the sulphur content of certain liquid fuels. https://eur-lex.europa.eu/legal-content/en/TXT/?uri=CELEX:32016L0802. Sourced on 9 March 2018.

${ }^{15}$ Directive 2012/33/EU of the European Parliament and of the Council of 21 November 2012 amending Council Directive 1999/32/EC as regards the sulphur content of marine fuels. https://eur-lex.europa.eu/legalcontent/EN/TXT/?uri=CELEX:32012L0033. Sourced on 31 August 2018.
} 

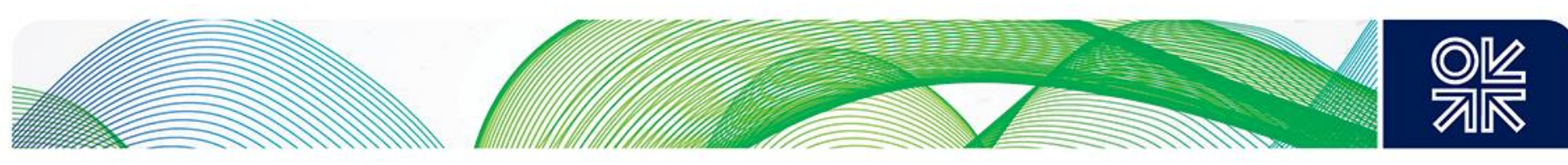

Finally, for comparison, in December 2015, the Chinese government announced its own plans (outside the IMO structures) to phase in $\mathrm{SO}_{x}$ emissions control areas in the Pearl River Delta, the Yangtze River Delta, and the Bohai Bay area, between January 2016 and January 2019. ${ }^{16}$ In December 2018, the Chinese government expanded the ECAs to cover the China's territorial waters (up to 12 nautical miles from the shore) along the country's entire coastline. Vessels operating in this area will be subject to a 0.5 per cent sulphur cap from January 2019, while seagoing vessels entering China's inland waterways will face a 0.1 per cent sulphur cap from January 2020. According to Platts, the Chinese Ministry of Transport is considering a 0.1 per cent limit in all ECAs from January 2025. ${ }^{17}$

To limit $\mathrm{SO}_{\mathrm{x}}$ emissions, and achieve regulatory compliance, ship owner/operators have a choice between:

1. Switching to a low-sulphur, oil-based fuel (such as low-sulphur marine gasoil, or LSMGO);

2. Installing an exhaust gas cleaning system (known as a 'scrubber') to remove $\mathrm{SO}_{\mathrm{x}}$ from the ship's exhaust gases - this enables the vessel to continue consuming high-sulphur fuel, or

3. Switching to $L N G$ as a shipping fuel, given that $L N G$ contains virtually no sulphur.

The technicalities of these options for meeting $\mathrm{SO}_{x}$ emissions standards have been discussed by Le Fevre, ${ }^{18}$ while this paper focuses specifically on the extent to which ship owners/operators in the North Sea/Baltic Sea region have chosen to switch to $L N G$ as their fuel.

\section{Limits on emissions of nitrogen oxides from shipping}

\section{IMO limits on $\mathrm{NO}_{x}$ emissions}

In addition to capping $\mathrm{SO}_{x}$ emissions, the IMO has also placed limits on nitrogen oxide $\left(\mathrm{NO}_{x}\right)$ emissions from shipping. As illustrated in Figure 2, the IMO currently imposes limits on $\mathrm{NO}_{x}$ emissions from ships operating anywhere in the world, if those ships were constructed after 2000 (Tier I) or after 2011 (Tier II). If those ships are operating in the North American or US Caribbean $\mathrm{NO}_{x}$ Emissions Control Areas and were constructed from 2016 onwards, more stringent limits apply (Tier III).

At MEPC 71, in July 2017, delegates adopted a resolution on amendments to MARPOL Annex VI, regarding restrictions on $\mathrm{NO}_{x}$ emissions. Those amendments (which entered into force on the $1^{\text {st }}$ of January 2019) designate the North Sea and Baltic Sea as Emissions Control Areas (ECAs) for $\mathrm{NO}_{x}$ emissions and apply Tier III restrictions to ships (constructed on or after the $1^{\text {st }}$ of January 2021) that operate in that NOx ECA. ${ }^{19,20}$

To put these limits into context, Trozzi and De Lauretis provide average $\mathrm{NO}_{x}$ emissions by engine and fuel type in 2010. For each engine type, emissions are given for those running on fuel oil (Bunker Fuel Oil, or BFO) and Marine Gasoil/Marine Diesel Oil (MGO/MDO). The three engine types are:

\footnotetext{
16 'Chinese Emission Control Areas (ECAs) effective from 1 January 2016', Policy Updates, UK Chamber of Shipping, 2015, 5 January. https://www.ukchamberofshipping.com/library/chinese-emission-control-areas-ecas-effective-1-january-2016/. Sourced on 6 September 2018.

17 'China's tighter sulfur limit rule for ships to spur LSMGO, LSFO demand', Platts, 2018, 18 December. https://www.spglobal.com/platts/en/market-insights/latest-news/shipping/121818-chinas-tighter-sulfur-limit-rule-for-ships-tospur-Ismgo-Isfo-demand. Sourced on 7 January 2019.

18 'A review of demand prospects for LNG as a marine fuel', Le Fevre, C., 2018. OIES Paper NG 33. Oxford Institute for Energy Studies, https://www.oxfordenergy.org/publications/review-demand-prospects-Ing-marine-fuel/. Sourced on 28 August 2018.

19 'Marine Environment Protection Committee (MEPC), 71st session 3-7 July 2017', Press release, IMO, 7 July 2017. www.imo.org/en/MediaCentre/MeetingSummaries/MEPC/Pages/MEPC-71.aspx. Sourced on 25 June 2018.

${ }^{20}$ Amendments to MARPOL annex VI (Designation of the Baltic Sea and the North Sea Emission Control Areas for NOX Tier III control), IMO, 2017. 

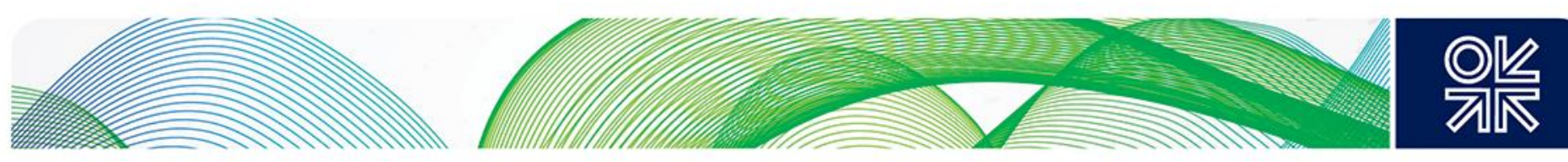

- 'slow speed' (up to 300 revolutions per minute (rpm), with Trozzi and De Lauretis noting that 'most operate at speeds of 80-140' rpm,

- 'medium-speed' (300-900 rpm), and

- 'high speed' (more than 900 rpm).

According to Trozzi and De Lauretis, when cruising in open waters, slow-speed engines averaged $\mathrm{NO}_{\mathrm{x}}$ emissions of 15.8-16.9 g/kWh; medium-speed engines averaged 12.3-13.0 g/kWh; and high-speed engines averaged 11.2-11.8 $\mathrm{g} / \mathrm{kWh}$. In the same report, Trozzi and De Lauretis estimated that the majority of container ships (93 per cent), dry bulk carriers (92 per cent), and liquid bulk ships (74 per cent) used slow-speed engines, while the majority of passenger vessels (77 per cent) and roll-on, rolloff (ro-ro) cargo ships (59 per cent) used medium-speed engines, while general cargo vessels were evenly divided (45 to 42 per cent) between slow and medium-speed engines. ${ }^{21}$

Figure 2: Current IMO limits on $\mathrm{NO}_{\mathrm{x}}$ emissions by ship construction date and engine speed

\begin{tabular}{|c|c|c|c|c|}
\hline \multirow{2}{*}{ Tier } & \multirow{2}{*}{$\begin{array}{c}\text { Ship construction } \\
\text { date on or after }\end{array}$} & \multicolumn{3}{|c|}{$\begin{array}{c}\text { Total weighted cycle emission limit (g/kWh) } \\
n=\text { engine's rated speed (rpm) }\end{array}$} \\
\cline { 3 - 5 } & & $n<130$ & $n=130-1999$ & $n \geq 2000$ \\
\hline I & 1 January 2000 & 17.0 & $\begin{array}{c}45^{*} \mathrm{n}^{(-0.2)} \\
\text { e.g., } 720 \mathrm{rpm}=12.1 \mathrm{~g} / \mathrm{kWh}\end{array}$ & $\begin{array}{c}44^{*} \mathrm{n}^{(-0.23)} \\
\text { II }\end{array}$ \\
\cline { 3 - 5 } & 1 January 2011 & 14.4 & e.g., $720 \mathrm{rpm}=9.7 \mathrm{~g} / \mathrm{kWh}$ & $\begin{array}{c}9^{*} \mathrm{n}^{(-0.2)} \\
\text { III }\end{array}$ \\
\cline { 3 - 5 } & 1 January 2016 & 3.4 & e.g., $720 \mathrm{rpm}=2.4 \mathrm{~g} / \mathrm{kWh}$ & 2.0 \\
\hline
\end{tabular}

Source: Nitrogen Oxides (NOx) - Regulation 13, IMO, 2018.22

These figures suggest that, in 2010 , vessels were likely to have $\mathrm{NO}_{x}$ emissions slightly above or slightly below the Tier I limits, depending on the age of the vessel and its engine speed. It is possible that incremental increases in engine efficiency (for example, due to design improvements) enable newer vessels, built since 2011, to meet the incremental tightening of restrictions from Tier I to Tier II.

More importantly, Tier III limits are substantially below average emissions for all engine types. Indeed, the application of Tier III limits to newbuild vessels operating in the North Sea or Baltic Sea ECAs from the $1^{\text {st }}$ of January 2021 requires a reduction of $\mathrm{NO}_{x}$ emissions of around 75 per cent compared to Tier II levels. Therefore, operation in a $\mathrm{NO}_{x}$ ECA requires abatement in order to meet the IMO regulations.

In order to burn oil-based fuels, vessels will require the installation of a Selective Catalytic Reduction (SCR) system or an Exhaust Gas Recirculation (EGR) system, to reduce the NO $x$ in the vessel's exhaust gas. $L N G$ propulsion is a viable alternative, given that $L N G$ produces just one tenth of the $\mathrm{NO}_{x}$ emissions of oil-based fuels. The issue of restrictions on $\mathrm{NO}_{x}$ emissions is likely to be a significant factor in fuel choices for newbuild vessels operating in the North Sea/Baltic Sea ECAs from 2021.

\footnotetext{
${ }^{21}$ International maritime navigation, international inland navigation, national navigation (shipping), national fishing, military (shipping), and recreational boats, Trozzi, C., and De Lauretis, R., LRTAP (Long-range Transboundary Air Pollution) European Environment Agency, 2016. https://www.eea.europa.eu/publications/emep-eea-guidebook-2016/part-b-sectoral-guidancechapters/1-energy/1-a-combustion/1-a-3-d-navigation. Sourced on 11 July 2018. See page 18 (Table 3-7) and page 22 (Table 3-10).

22 Nitrogen Oxides $\left(\mathrm{NO}_{x}\right)$ - Regulation 13, IMO, 2018. http://www.imo.org/en/OurWork/Environment/PollutionPrevention/AirPollution/Pages/Nitrogen-oxides-(NOx)-\%E2\%80\%93Regulation-13.aspx. Sourced on 25 June 2018.
} 

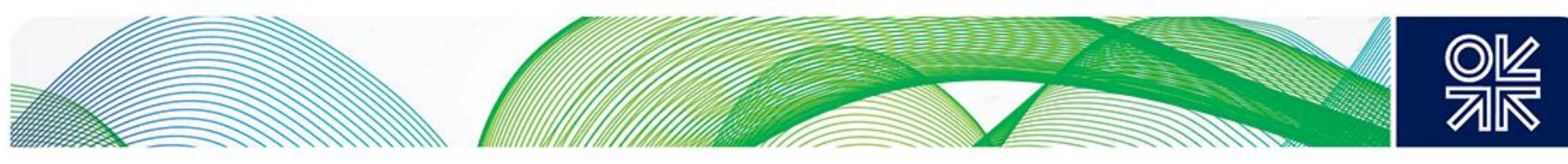

\section{Norwegian national limits on $\mathrm{NO}_{x}$ emissions}

Norway provides an illustrative example of the impact of $\mathrm{NO}_{x}$ emissions restrictions on shipping, and the potential for such restrictions to encourage the shift to LNG as a shipping fuel. In January 2007, the Norwegian government introduced a new tax on $\mathrm{NO}_{x}$ emissions and then, 12 months later, launched the Business Sector $\mathrm{NO}_{x}$ Fund. Under the new arrangement, affiliated enterprises are exempt from the $\mathrm{NO}_{x}$ tax, and instead pay into the $\mathrm{NO}_{x}$ Fund. The Fund is then used to provide financial support for $\mathrm{NO}_{x}$ reduction measures by enterprises that have paid into the Fund. Crucially, payments into the $\mathrm{NO}_{x}$ Fund are lower than the $\mathrm{NO}_{x}$ tax, thus encouraging participation. A further point to note is that emissions from vessels travelling directly to Norway from a foreign port, conducting (un)loading or (dis)embarkation (upon arrival from a foreign port), and leaving Norway to travel directly to a foreign port, are exempt from the NOx tax - the NOx tax targets domestic Norwegian shipping. ${ }^{23}$ The agreement on the $\mathrm{NO}_{\mathrm{x}}$ Fund was recently extended, to cover the period 2018-25.24

For the period 2008-18, the Fund supported the installation of SCR or EGR systems for 167 vessels, and conversion to LNG propulsion for 45 vessels, including four small-scale LNG carriers. This means that 41 vessels other than LNG carriers received support for conversion to LNG propulsion. DNV GL lists 61 Norwegian LNG-fuelled vessels by name (excluding LNG carriers), which were active as of December 2018. According to that list, Norway has 26 LNG-fuelled ferries, of which ten appear on the list of vessels that benefitted from financial support from the $\mathrm{NO}_{x}$ Fund. Financial support was also provided for all four of Norway's LNG-fuelled chemical/product tankers, all five general cargo vessels, both of Norway's LNG-fuelled roll-on, roll-off (ro-ro) cargo vessels, all five tugs, and 13 of Norway's 16 offshore Platform Service Vessels (PSVs). DNV GL also lists three Norwegian LNG-fuelled patrol vessels that did not receive financial support. Finally, the $\mathrm{NO}_{x}$ Fund list includes a further two oil product/chemical tankers that the DNV GL class as 'European' rather than 'Norwegian'. 25,26

This means that 39 out of Norway's 61 LNG-propelled vessels (excluding LNG carriers) listed by DNV GL have benefitted from financial support from the $\mathrm{NO}_{x}$ Fund. If the two additional oil product/chemical tankers (that are classified by DNV GL as 'European' rather than 'Norwegian') are included, this ratio becomes 41 out of 63 . The 22 vessels that did not receive financial support include 16 ferries, three PSVs, and three patrol vessels. Of these 22 vessels, four were launched between 2000 and 2006 (that is, before the $\mathrm{NO}_{\mathrm{x}}$ tax and Fund were instituted), and a further four were launched in 2007 (after the tax was instituted but before the $\mathrm{NO}_{x}$ Fund made subsidies available). Therefore, around two-thirds of Norway's LNG-fuelled marine fleet was subsidised by the Norwegian $\mathrm{NO}_{x}$ Fund. When only vessels launched after the $\mathrm{NO}_{x}$ Fund made subsidies available (in other words, from 2008 onwards) are considered, that share rises to 74 per cent. This tax and subsidy, along with Norway's substantial domestic natural gas reserves and production, could explain why LNG propulsion developed more quickly in Norway than in neighbouring countries.

\section{Monitoring, regulating, and reducing $\mathrm{CO}_{2}$ emissions from shipping}

At MEPC 72, in April 2018, delegates adopted a resolution on the 'Initial strategy on the reduction of greenhouse gas (GHG) emissions from shipping'. The aims are to reduce $\mathrm{CO}_{2}$ emissions from shipping by 40 per cent by 2030 , and by 70 per cent by 2050 , and to reduce total greenhouse gas emissions by

\footnotetext{
${ }^{23}$ The NOx Fund - Regulations, NHO, 2018. https://www.nho.no/samarbeid/nox-fondet/the-nox-fund/articles/regulations/. Sourced on 3 September 2018.

${ }^{24}$ About the NOx Fund, NHO, 2018. https://www.nho.no/samarbeid/nox-fondet/the-nox-fund/articles/about-the-nox-fund/. Sourced on 20 August 2018.

${ }^{25}$ Alternative Fuels Insight platform, DNV GL, 2018. https://www.dnvgl.com/services/alternative-fuels-insight-128171. Sourced on 20 September 2018.

${ }^{26}$ Overview of approved support for measures from 2008 until November 2018, NHO, 2018.

https://www.nho.no/samarbeid/nox-fondet/the-nox-fund/articles/granted-support/. Sourced on 27 November 2018.
} 

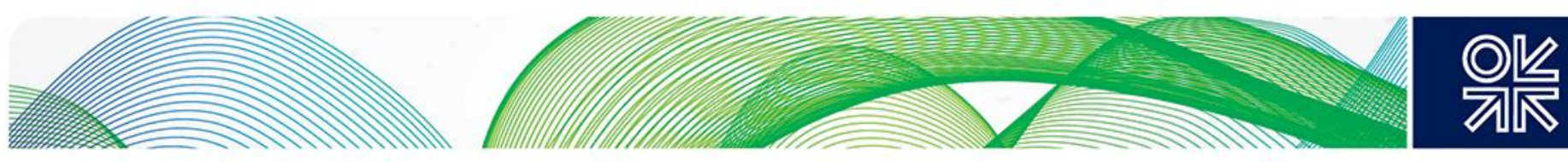

50 per cent by 2050 , compared to $2008 .{ }^{27}$ The initial strategy will remain under review until the adoption of a revised strategy in the spring of 2023.28

Complementary efforts by the IMO include more stringent energy efficiency standards for ships, and closer monitoring of fuel oil consumption in ships. Firstly, in July 2011, MEPC 62 adopted a mandatory Energy Efficiency Design Index (EEDI) for the construction of new ships. Under this programme, from January 2013, 'new ship designs need to meet the reference level for their ship type. The level is to be tightened incrementally every five years', leading to a 30 per cent reduction in grams of $\mathrm{CO}_{2}$ emissions per tonne mile by 2025, compared to the average of ships of the same class built between 2000 and 2010. ${ }^{29}$ This was partnered with the promotion of increased operational energy efficiency through the implementation of a Ship Energy Efficiency Management Plan (SEEMP). ${ }^{30}$

Then, at MEPC 70 in October 2016, delegates adopted a resolution on the mandatory collection of data on fuel consumption in ships (MEPC.278 [70]). The resolution, which entered into force on the $1^{\text {st }}$ of March 2018, requires ships of 5,000 gross tonnes and above 'to collect consumption data for each type of fuel oil they use'. The data is submitted to the flag state and then passed on to the IMO, which will then produce an annual report for MEPC, summarising the data. ${ }^{31}$ That database will likely inform the revised $\mathrm{IMO} \mathrm{CO}_{2}$ emissions reduction strategy in 2023.

That MEPC resolution on the collection of shipping fuel data complemented EU regulation 2015/757, which requires the monitoring, reporting, and verification (MRV) of $\mathrm{CO}_{2}$ emissions released by ships with a gross tonnage of 5,000 or more during their voyages to and from EU ports. ${ }^{32}$

At MEPC 70, a further resolution was adopted, amending the existing guidelines on the calculation of the energy efficiency design index for ships (MEPC.281 [70]). Annex 9 of that resolution proposes the calculation of $\mathrm{CO} 2$ emissions by multiplying fuel consumption by an 'emissions factor' (tonnes of $\mathrm{CO} 2$ emitted per tonne of fuel consumed, based on the carbon content of the fuel). ${ }^{33}$ In September 2016, EU Regulation 2015/757 was amended to include the same emissions factors as the MEPC resolution. ${ }^{34}$

\footnotetext{
27 'UN body adopts climate change strategy for shipping', IMO, Press release, 13 April 2018. www.imo.org/en/MediaCentre/PressBriefings/Pages/06GHGinitialstrategy.aspx. Sourced on 16 May 2018. 28 'Adoption of the initial IMO strategy on reduction of GHG emissions from ships and existing IMO activity related to reducing GHG emissions in the shipping sector, IMO, 2018. https://unfccc.int/sites/default/files/resource/250 IMO\%20submission Talanoa\%20Dialogue April\%202018.pdf. Sourced on 16 May 2018. See page 11.

${ }^{29}$ Energy Efficiency Measures, IMO, 2018.

www.imo.org/en/OurWork/Environment/PollutionPrevention/AirPollution/Pages/Technical-and-Operational-Measures.aspx. Sourced on 16 May 2018.

${ }^{30} 2016$ guidelines for the development of a ship energy efficiency management plan (SEEMP). London: IMO, 2016. www.imo.org/en/OurWork/Environment/PollutionPrevention/AirPollution/Documents/Res MEPC 282\%2870\%29 2016\%20Gui delines $\% 20$ for $\% 20$ the $\% 20$ development $\% 20$ of $\% 20$ a $\% 20$ SEEMP $\% 20 \% 28$ including $\% 20$ Corrigendum $\% 29$. pdf. Sourced on 1 June 2018.

${ }^{31}$ Data collection system for fuel oil consumption of ships, IMO, 2018. www.imo.org/en/OurWork/Environment/PollutionPrevention/AirPollution/Pages/Data-Collection-System.aspx. Sourced on 16 May 2018.

${ }^{32}$ Regulation (EU) 2015/757 of the European Parliament and of the Council of 29 April 2015 on the monitoring, reporting and verification of carbon dioxide emissions from maritime transport, and amending Directive 2009/16/EC.

${ }^{33}$ Resolution MEPC.281(70) (adopted on 28 October 2016). Amendments to the 2014 guidelines on the method of calculation of the attained energy efficiency design index (EEDI) for new ships (resolution mepc.245(66), as amended by resolution mepc.263(68)). Annex 9. http://www.imo.org/en/KnowledgeCentre/IndexoflMOResolutions/Marine-Environment-ProtectionCommittee-(MEPC)/Documents/MEPC.281(70).pdf. Sourced on 22 January 2019. (See page 3).

${ }^{34}$ Regulation (EU) 2015/757 (Consolidated version). https://eur-lex.europa.eu/legal-content/EN/TXT/?uri=CELEX:02015R075720161216. Sourced on 22 January 2019. (See Annex I).
} 

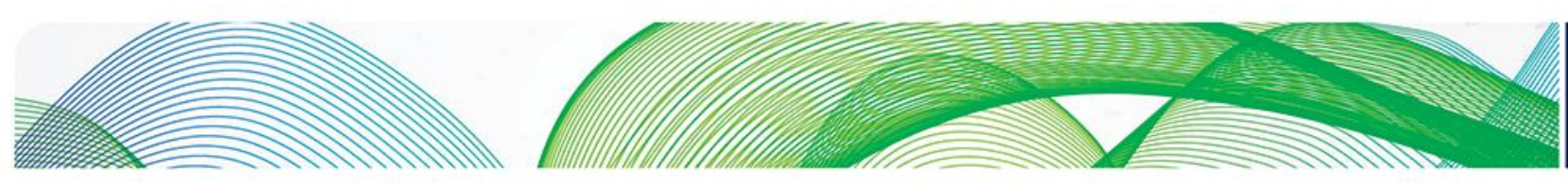

The emissions factors for different marine fuels used by the IMO and EU include:

- Marine Diesel/Marine Gasoil (3.206);

- $\quad$ Light Fuel Oil (3.151);

- Heavy Fuel Oil (3.114); and

- LNG (2.570).

These factors suggest that a switch from marine diesel/marine gasoil to $L N G$ would reduce $\mathrm{CO}_{2}$ emissions per tonne of fuel consumed by 19.8 per cent, while a switch from HFO to LNG would reduce $\mathrm{CO}_{2}$ emissions per tonne of fuel consumed by 17.5 per cent.

However, to gain a more nuanced understanding of the issue, the different energy content of set amounts of these different fuels should be considered. As the table below illustrates, when these fuels are measured by density (kilograms per litre), LNG is approximately half the weight of Heavy Fuel Oil, Light Fuel Oil, and Marine Gasoil. As a result, LNG has a greater energy content by weight (megajoules per kilogram) than the oil-based fuels. Conversely, LNG has a substantially lower energy content by liquid volume (megajoules per litre) than the oil-based fuels.

Figure 3: Energy content of marine fuels

\begin{tabular}{|c|c|c|c|c|c|c|c|c|}
\hline \multicolumn{9}{|c|}{ Energy content of marine fuels } \\
\hline & \multicolumn{2}{|c|}{ Density } & \multicolumn{2}{|c|}{$\begin{array}{l}\text { Power by weight } \\
\quad(\mathrm{kWh} / \mathrm{kg})\end{array}$} & \multicolumn{2}{|c|}{$\begin{array}{l}\text { Energy by weight } \\
(M J / k g)\end{array}$} & \multicolumn{2}{|c|}{$\begin{array}{c}\text { Energy by volume } \\
\text { (MJ/litre) }\end{array}$} \\
\hline & $\begin{array}{r}\text { Kg per } \\
\text { litre }\end{array}$ & $\begin{array}{r}\text { Litres per } \\
\mathrm{kg}\end{array}$ & $\begin{array}{l}H H V / \\
G C V\end{array}$ & $\begin{array}{l}\text { LHV/ } \\
N C V\end{array}$ & $\begin{array}{l}H H V / \\
G C V\end{array}$ & $\begin{array}{l}\text { LHV/ } \\
N C V\end{array}$ & $\begin{array}{l}H H V / \\
G C V\end{array}$ & $\begin{array}{l}\text { LHV/ } \\
\text { NCV }\end{array}$ \\
\hline LNG & 0.428 & 2.336 & 15.33 & 13.50 & 55.2 & 48.6 & 23.6 & 20.8 \\
\hline $\begin{array}{l}\text { Marine } \\
\text { gasoil }\end{array}$ & 0.855 & 1.170 & 12.75 & 11.89 & 45.9 & 42.8 & 39.2 & 36.6 \\
\hline $\begin{array}{l}\text { Light } \\
\text { fuel oil }\end{array}$ & 0.960 & 1.042 & 12.22 & 11.28 & 44.0 & 40.6 & 42.2 & 39.0 \\
\hline $\begin{array}{l}\text { Heavy } \\
\text { fuel oil }\end{array}$ & 0.980 & 1.020 & 11.61 & 10.83 & 41.8 & 39.0 & 41.0 & 38.2 \\
\hline & ating & ue $(\mathrm{HHV}) / \mathrm{G}$ & & $\overline{G C V})$ a & & & $\begin{array}{r}\text { et Calorific } \\
@ 15\end{array}$ & $\begin{array}{l}(\mathrm{NCV}) \\
1 \text { bar }\end{array}$ \\
\hline
\end{tabular}

Source: Engineering Toolbox ${ }^{35}$

There are three key implications for this set of comparisons. The first is financial. Given that bunker fuel prices are measured in USD per tonne, the greater energy content of LNG per tonne is one factor that makes it cheaper than marine gasoil and price-competitive with heavy fuel oil on a per-tonne basis.

The second factor is practical. Because the energy content of LNG by volume (MJ per litre) is just 57 60 per cent that of marine gasoil and 53-58 per cent that of light and heavy fuel oil, a vessel must consume a greater volume of LNG in order to travel the same distance. This means that the LNG fuel tanks on board the vessel (as measured in litres) must be substantially larger than tanks for marine

\footnotetext{
${ }^{35}$ Fuels - Higher and Lower Calorific Values, Engineering Toolbox, 2003. https://www.engineeringtoolbox.com/fuels-highercalorific-values-d 169.html. Sourced on 22 January 2019.
} 

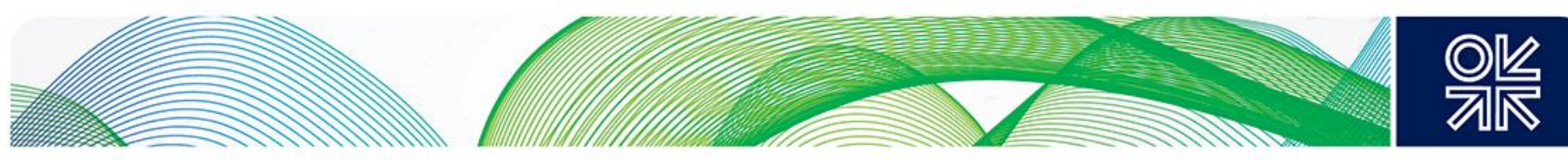

gasoil or heavy/light fuel oil in order to achieve the same range (the number of nautical miles that can be travelled on a single tank of fuel).

The third factor is environmental. The greater energy content of LNG per tonne means that fewer tonnes of LNG must be consumed to generate the same amount of power. Therefore, not only does LNG produce less $\mathrm{CO} 2$ per tonne of fuel consumed, but fewer tonnes of fuel must be consumed in order to generate the same amount of power, and thus travel the same distance.

For example, to generate $100 \mathrm{kWh}$ of power (net calorific value), a vessel running on LNG must consume $7.407 \mathrm{~kg}$ (17.303 litres) of fuel. For comparison, a vessel running on marine gasoil must consume $8.410 \mathrm{~kg}$ (9.840 litres) of fuel, while a vessel running on heavy fuel oil must consume 9.234 $\mathrm{kg}$ (9.419 litres) of fuel. In calorific terms, these all equate to $360 \mathrm{MJ}$ of energy consumed.

Using the emissions factors stated above, if one kilogramme of LNG consumed produces one $2.750 \mathrm{~kg}$ of $\mathrm{CO} 2$, the consumption of $7.407 \mathrm{~kg}$ of LNG to generate $100 \mathrm{kWh}$ of power results in the emission of $20.369 \mathrm{~kg}$ of CO2. For comparison, marine gasoil produces $26.962 \mathrm{~kg}$ of CO2 for every $100 \mathrm{kWh}$ of power generated ( $8.410 \mathrm{~kg}$ of fuel consumed multiplied by an emissions factor of 3.206), while for heavy fuel oil the figure is $28.755 \mathrm{~kg}$ for every $100 \mathrm{kWh}$ of power generated $\left(9.234^{*} 3.114\right)$.

Therefore, switching from heavy fuel oil to LNG results in a 29.2 per cent reduction in $\mathrm{CO} 2$ emissions on the basis of power output from fuel combustion, while switching from marine gasoil to LNG results in a 24.5 per cent reduction in $\mathrm{CO} 2$ emissions on a power-output basis.

However, it must be clearly stated that these calculations do not take into account the 'life cycle' impact of these different fuels, which would include the energy expended to produce the fuel and deliver it to the relevant bunkering facilities, nor does it address the environmental impact of 'methane slip', where unburnt methane escapes during the combustion process. ${ }^{36}$ In a report published on behalf of the Natural Gas Vehicles Association (NGVA), Thinkstep estimate that switching from Heavy Fuel Oil to LNG results in reductions of 'well-to-wake' greenhouse gas emissions of 11 per cent (dual-fuel, fourstroke LNG engine) and 21 per cent (dual-fuel, two-stroke engine). Those reductions include a 27 per cent reduction in $\mathrm{CO}_{2}$ emissions, offset by methane emissions from both the supply and combustion processes, thus giving an overall reduced benefit in GHG emissions reduction of 11-21 per cent. ${ }^{37}$

Between them, the measures noted above suggest that $\mathrm{CO}_{2}$ emissions from shipping are expected to be reduced through a combination of increased fuel efficiency and fuel switching. For example, a switch from marine diesel/marine gasoil or HFO to LNG (thus reducing $\mathrm{CO}_{2}$ emissions by around 24.5-29.2 per cent) combined with the attainment of the 30 per cent energy efficiency improvement target set by the IMO would lead to 55-60 per cent reduction in $\mathrm{CO}_{2}$ emissions per unit of distance travelled, thus achieving the IMO aim of a 40 per cent reduction in shipping-sector $\mathrm{CO}_{2}$ emissions by 2030 , and approaching the target of reducing $\mathrm{CO}_{2}$ emissions by 70 per cent by 2050 .

Similarly, the aim of reducing GHG emissions by 50 per cent by 2050 could be approached by a combination of increased energy efficiency (30 per cent reduction) and an 11-21 per cent reduction in GHG emissions achieved by fuel-switching. However, this very much represents a 'ceiling' for $\mathrm{CO}_{2}$ and GHG emissions reductions through fuel-switching to LNG. In the longer term future, the attainment of low or zero-carbon shipping would require more drastic measures.

Finally, it is worth noting that while shipping-sector emissions are currently excluded from the EU Emissions Trading Scheme, this may not be the case forever. In December 2017, the European

\footnotetext{
${ }^{36}$ Le Fevre, 2018. See pages 2-3.

${ }^{37}$ Greenhouse Gas Intensity of Natural Gas, 2017. Thinkstep (on behalf of the Natural Gas Vehicles Association). http://ngvemissionsstudy.eu/. Sourced on 5 February 2019. See section 7.3.4.Well-to-Wake-GHG Emissions: Ships (pp.88-90)
} 

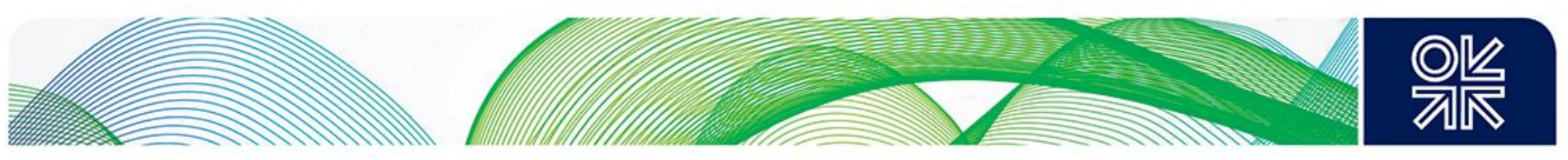

Parliament adopted 'A European Strategy for Low-Emission Mobility'. Crucially, Article 124 of that text stresses that:

$\ldots$ in the absence of a comparable system operating under the $\mathrm{IMO}, \mathrm{CO}_{2}$ emissions emitted at Union ports and during voyages to and from Union ports should be subject to the EU ETS as of $2023 .{ }^{38}$

This puts pressure on the IMO to ensure that its own $\mathrm{CO}_{2}$ emissions-reduction strategy (to be formulated by 2023 ) is sufficiently stringent, to avoid the EU taking matters into its own competence.

\section{LNG as a shipping fuel}

\section{Environmental credentials regarding $\mathrm{SO}_{\mathrm{x}}$ and $\mathrm{NO}_{x}$}

Over the past decade, the introduction of national $\mathrm{NO}_{\mathrm{x}}$ emissions restrictions in Norway, and the introduction of $\mathrm{SO}_{x}$ emissions restrictions in the Baltic Sea and North Sea ECAs in 2006/07 (with the latter tightened in 2010 and 2015), has provided a regulatory framework that forced ship owners/operators to adapt their commercial practices. LNG has emerged as an environmentally feasible option for meeting these emissions standards because LNG contains virtually no sulphur, just one tenth of the $\mathrm{NO}_{x}$ of oil-based fuels, and virtually no particulate matter (PM). ${ }^{39}$

In the North Sea and Baltic Sea ECAs, the introduction of restrictions on $\mathrm{NO}_{x}$ emissions for newbuild vessels from 2021 will strengthen the case for ship owners/operators choosing alternatives to oil-based propulsion for their new vessels, including LNG. Meanwhile, the tightening of global restrictions on $\mathrm{SO}_{x}$ emissions will strengthen the case for alternative fuels beyond the regional ECAs. Furthermore, targets for reductions of $\mathrm{CO}_{2}$ emissions from shipping will be a significant factor in fuel choices by ship owners/operators planning to purchase newbuild vessels.

In an increasingly stringent environmental context, LNG is certainly not a 'silver bullet', but rather, when combined with improvements in energy efficiency, it offers a potential pathway to regulatory compliance in relation to $\mathrm{CO}_{2}, \mathrm{SO}_{x}$, and $\mathrm{NO}_{x}$ emissions, together with some measure of 'future-proofing' against potential future restrictions on PM emissions. Given that marine vessels usually have working lives of two or three decades, the increasingly efficient LNG-fuelled vessels launched in the 2020s may remain in service until the late 2040s, at which point technological advances regarding alternative fuels may render zero (or near-zero) carbon shipping a realistic aim by 2050.

\section{Price considerations}

\section{Existing vessels}

Given that $\mathrm{NO}_{\mathrm{x}}$ emissions restrictions have only applied to newbuild vessels in North America since 2016, and will only apply to vessels in the North Sea/Baltic Sea region from 2021, while the question of $\mathrm{CO}_{2}$ emissions is one for a longer-term future, owners of existing vessels have been - and will continue to be - most concerned with how to adapt to $\mathrm{SO}_{\mathrm{x}}$ emissions restrictions.

\footnotetext{
${ }^{38}$ A European Strategy for Low-Emission Mobility, European Parliament, 2017 [Adopted 14 December]. www.europarl.europa.eu/sides/getDoc.do?type=TA\&reference=P8-TA-2017-0503\&language=EN\&ring=A8-2017-0356. Sourced on 23 August 2018.

${ }^{39}$ Studies on the feasibility and use of LNG as a fuel for shipping. London: IMO, 2016. www.imo.org/en/OurWork/Environment/PollutionPrevention/AirPollution/Documents/LNG\%20Study.pdf. Sourced on 27 June 2018. See page 65.
} 

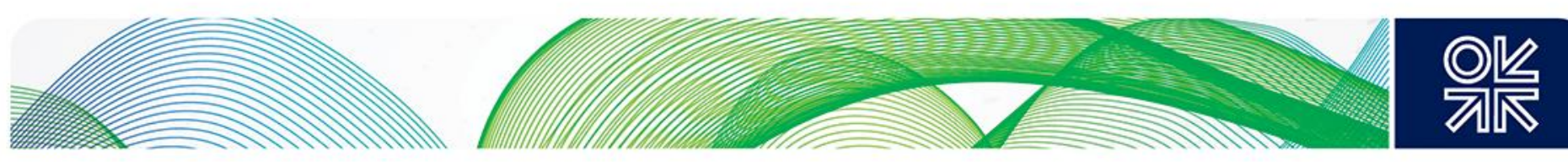

At this point, discussion of the commercial viability of different $\mathrm{SO}_{x}$ abatement methods must be divided between the existing fleet (in the context of the current and post-2020 regulatory regimes), and the newbuild fleet (also under the current and post-2020 regimes).

For the existing fleet under the current $\mathrm{SO}_{x}$ emissions regime, abatement is only necessary if a vessel spends time in a $\mathrm{SO}_{x}$ Emissions Control Area (ECA). The proportion of time a vessel spends in an ECA dramatically affects the commercial attractiveness of different abatement methods. For a vessel that spends its entire time in an ECA, the cost of capital investment in retrofitting to run on LNG, or the installation of a scrubber, must be compared with the alternative higher operational costs of running on low-sulphur fuel, such as low-sulphur marine gasoil (LSMGO).

In terms of fuel costs, Figure 4 shows the price of LNG bunker fuel in North-Western Europe (Free on Truck) in US\$ per tonne of marine gasoil equivalent (MGOe), relative to low-sulphur marine gasoil (LSMGO) and fuel oil (HFO 180 and 380). Crucially, LNG bunker fuel has not only consistently traded at a substantial discount to LSMGO, but has also been price-competitive with HFO 180/380.

For the full-year 2018, LNG was, on average, US\$220 per tonne cheaper than ECA-compliant LSMGO, and US\$64/US\$38 per tonne cheaper than HFO 180/380. The decline in oil prices in Q4 2018, from US $\$ 85$ to US $\$ 50$ per barrel (US $\$ 633$ to US $\$ 391$ per tonne), brought those spreads down. In December, LNG was, on average, US $\$ 120$ per tonne cheaper than LSMGO, while the prices of HFO 180 and 380 dipped slightly below that of LNG, to monthly average discounts of US $\$ 30$ and $\$ 4$ per tonne, respectively. This shows that, even with strongly declining oil prices in Q4 2018, LNG retained a substantial discount relative to LSMGO, and remained competitive with HFO.

Figure 4: Bunker fuel prices in NW Europe (US\$ per tonne)

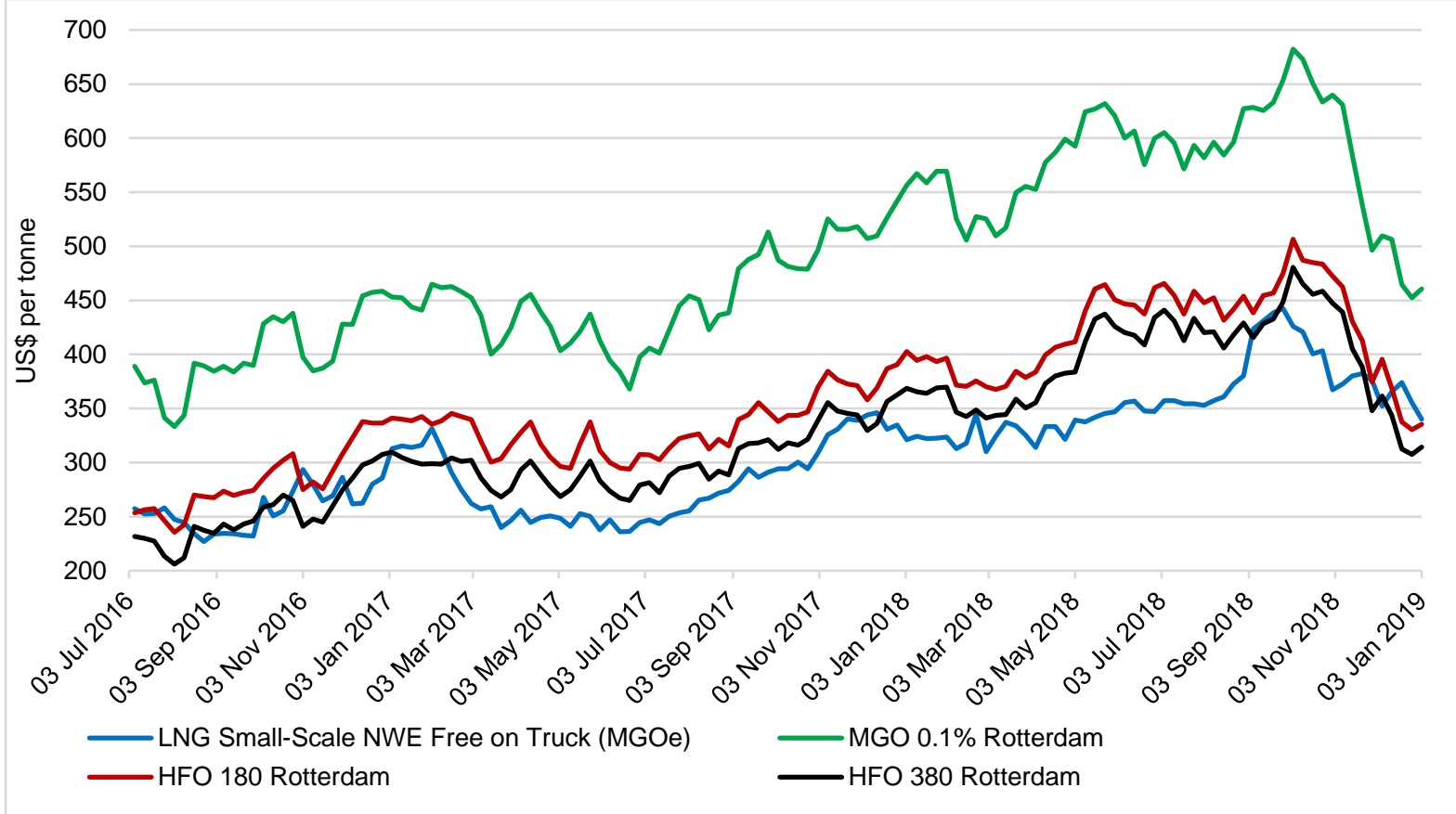

Source: Graph created by author with data from Argus Direct.

Variations in price spreads between these fuels substantially alters the calculations of payback times for investment in LNG propulsion and scrubbers, while the difficulty of predicting these spreads several years into the future presents a significant risk for ship owners debating how best to comply with tightening environmental regulations. The examples below illustrate the nature of the calculations being 

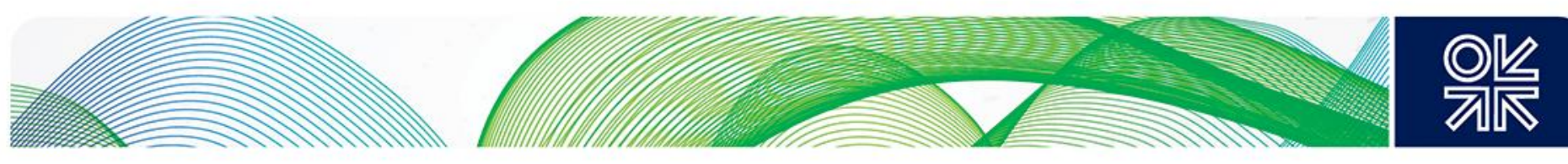

made by those ship owners, given that the cost of retrofitting to run on LNG or of installing a scrubber varies dramatically according to vessel size.

Clean Marine Energy estimate that a vessel consuming 5 metric tonnes of marine gasoil per day would cost US\$6m to retrofit, while a large vessel consuming 80 metric tonnes per day would cost around US $\$ 22 \mathrm{~m}$ to convert. ${ }^{40}$ Based on LNG being US $\$ 200$ per tonne cheaper than LSMGO, it is possible to make a rough estimate that a vessel consuming 5 tonnes of fuel per day would take 16.4 years to recoup US $\$ 6 \mathrm{~m}$ of capital investment in LNG retrofitting. By contrast, a vessel consuming 80 tonnes per day would take 3.8 years to recoup US $\$ 22 \mathrm{~m}$. For comparison, the installation of scrubbers on vessels of similar sizes are estimated to cost around US\$2m and US\$8m, respectively. ${ }^{41}$ In this case, and assuming that HFO 380 is US $\$ 200$ per tonne cheaper than LSMGO, a vessel consuming 5 tonnes per day of fuel would take 5.5 years to recoup US $\$ 2 \mathrm{~m}$ of capital investment for scrubber installation, while a vessel consuming 80 tonnes per day would take 1.4 years to recoup US $\$ 8 \mathrm{~m}$.

If a vessel only spends half of its time in an ECA, and could therefore continue to consume high-sulphur HFO for half of its time, the option of fuel-switching between HFO and LSMGO (without the need for capital investment in a scrubber or LNG propulsion) becomes more attractive. With LSMGO being $\$ 200$ per tonne more expensive than HFO, dividing fuel consumption equally between the two would result in fuel costs of $\$ 100$ per tonne less than pure consumption of LSMGO.

On this basis, a small vessel consuming 5 tonnes of fuel per day split equally between HFO and LSMGO would have fuel costs $\$ 500$ per day ( $\$ 182,500$ per year) cheaper than the cost of purely consuming LSMGO. It would take that vessel 11 years to recoup a $\$ 2 \mathrm{~m}$ investment in a scrubber, and 33 years to recoup a $\$ 6 \mathrm{~m}$ investment in LNG retrofitting, on the basis of cheaper fuel costs. For a large vessel consuming 80 tonnes of fuel per day split equally between HFO and LSMGO, fuel costs would be $\$ 8,000$ per day ( $\$ 2.92 \mathrm{~m}$ per year) cheaper than the cost of purely consuming LSMGO. It would take that vessel 2.7 years to recoup an $\$ 8 \mathrm{~m}$ investment in a scrubber and 7.5 years to recoup a $\$ 22 \mathrm{~m}$ investment in LNG retrofitting. These costs explain why vessel owners have been relatively reluctant to invest either in LNG retrofitting or scrubber installation for existing vessels, unless their vessel is spending the vast majority of its time in an ECA.

For vessels that do spend time in ECAs, the installation of scrubbers has proved more attractive to ship owners willing to invest further capital in their existing vessels, while paying a premium for LSMGO has proved more attractive to ship owners who are unwilling to invest further capital in their existing vessels. Again, the balance between the two is strongly influenced by the level of annual fuel consumption for the vessel concerned, with owners of larger vessels more likely to opt for scrubbers and owners of smaller vessels more likely to pay a premium for low-sulphur fuel.

The crucial aspect of the change in IMO regulations taking place in January 2020 is that all vessels operating anywhere in the world will be required to take action to reduce their $\mathrm{SO}_{x}$ emissions. Continuing to burn high-sulphur HFO with no abatement will no longer be an option. Vessel owners will be forced to choose between:

- $\quad$ higher fuel costs (burning low-sulphur fuel oil ( 0.5 per cent $\mathrm{SO}_{\times}$) outside ECAs and LSMGO $(0.1$ per cent sulphur) inside ECAs;

- the installation of a scrubber and continued consumption of high-sulphur fuel oil; and

\footnotetext{
40 'Industry Insight: A survival guide for evaluating the cost of converting a vessel to use LNG bunkers', Ralli, P., Ship \& Bunker, 1 December 2015. https://shipandbunker.com/news/features/industry-insight/566977-industry-insight-a-survival-guide-forevaluating-the-cost-of-converting-a-vessel-to-use-Ing-bunkers. Sourced on 17 September 2018.

41 'Industry insight: Viability of scrubbers for different type of vessels', Vis, R., Ship \& Bunker, 10 January 2018. https://shipandbunker.com/news/features/industry-insight/173331-industry-insight-viability-of-scrubbers-for-different-type-ofvessels. Sourced on 18 July 2018.
} 

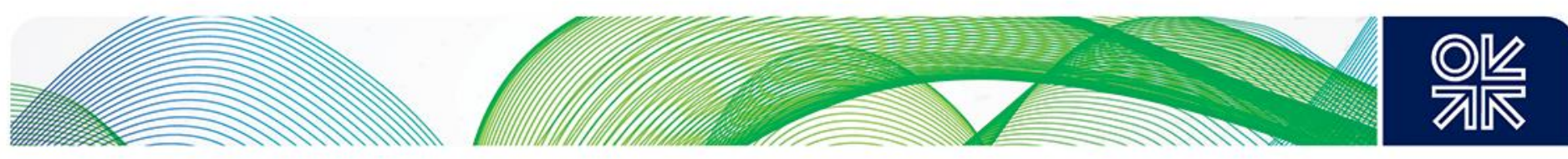

- the use of LNG as a shipping fuel.

Post-2020, the price of IMO-compliant oil-based fuels (LSMGO or a 0.5 per cent sulphur fuel oil blend) is set to rise, and the price of non-compliant fuels is set to fall. The production of sufficient volumes of IMO-compliant fuel oil (by blending non-compliant high-sulphur fuel oil with low-sulphur distillates) and IMO-compliant low-sulphur marine gasoil (a refined middle distillate fuel) to meet demand from ship owners who have not installed scrubbers or switched to an alternative fuel, remains a significant challenge for the global refining industry. It is a challenge they are likely to meet, but at the cost of greater volumes of crude oil consumption for refining, which may push crude oil prices upwards. At the same time, small ports with limited bunker fuel storage capacity may choose to stock only IMOcompliant fuel, making it harder for vessels with scrubbers to source cheaper high-sulphur fuel oil.

Meanwhile, vessel owners/operators will calculate how much time their vessels will spend inside ECAs (with 0.1 per cent $\mathrm{SO}_{x}$ limits) and outside ECAs (with 0.5 per cent $\mathrm{SO}_{x}$ limits), and whether regular fuelswitching (between LSMGO and 0.5 per cent fuel oil), scrubber operation, or a switch to LNG is the most commercially attractive path to regulatory compliance. The substantial size of the necessary capital investment has largely dissuaded vessel owners from retrofitting their existing vessels with either scrubbers or LNG propulsion, as illustrated by the currently limited number of vessels undergoing such adaptation, relative to the size of the global fleet. The relative costs of scrubber installation and LNG retrofitting may explain why, in cases where the vessel owner is willing to make a capital investment in order to avoid purchasing (more expensive) marine gasoil, scrubbers are currently more popular than LNG. The expected sharp decline of non-compliant fuel oil prices from late 2019 will make scrubbers more appealing for existing vessels. For those unwilling to make such an investment, acceptance of higher prices for compliant fuels represents a 'wait and see' option, until their fleet turnover enables them to purchase a new vessel, at which point they will decide between a pre-installed scrubber or LNG propulsion.

\section{Newbuild vessels}

For newbuild vessels, the economic considerations are slightly different. Given that the installation of a scrubber or LNG propulsion is cheaper in a newbuild than as a retrofit to an existing vessel, the payback period is shortened. For example, Fearnley LNG estimate that the conversion of an existing 8,500 TEU42 capacity container ship to LNG would cost $\$ 28 \mathrm{~m}$, while the choice of LNG propulsion in a newbuild vessel of the same type would cost $\$ 13 \mathrm{~m}$ over and above the cost of a vessel running on oil-based fuel. ${ }^{43}$ For scrubber installation, the difference between newbuild and retrofit is not nearly so stark. For example, Clarksons estimate that the installation of a scrubber on a newbuild 12,000-14,999 TEU capacity container ship would be $\$ 5-6 \mathrm{~m}$, compared to a retrofit cost of $\$ 6-7 \mathrm{~m} .{ }^{44}$ Finally, using the example of a newbuild 50,000 DWT (deadweight tonne) medium-range oil tanker, DNV GL estimate the cost of choosing an LNG-capable dual-fuel system to be $\$ 5.8 \mathrm{~m}$ more than a conventional oil-based fuel system, while the installation of a scrubber would be $\$ 3.3 \mathrm{~m} .{ }^{45}$

Given that costs vary dramatically according to vessel size and type, these comparisons should only be considered as indicative of the fact that that installing LNG propulsion during the construction of a new vessel is far cheaper than retrofitting an existing vessel. Likewise, under current conditions, the

\footnotetext{
42 TEU: Twenty-foot Equivalent Unit.

43 'Competing on price: Making LNG as a bunker fuel commercially viable', Fearnley LNG, Presentation at Platts Annual LNG Conference, 10 February 2017.

https://www.platts.com/IM.Platts.Content/ProductsServices/ConferenceandEvents/americas/liquefied-naturalgas/presentations2017/Michael Newman.pdf. Sourced on 5 October 2018.

44 SOx 2020: Effects on the oil products markets, Clarksons, 2017. www.clarksons.net/docdata/public/newsdownloads/SOx 2020 Oil Products Markets.pdf. Sourced on 5 October 2018.

45 'LNG as fuel on a new build MR tanker - a commercially attractive option?', LNG as a Ship Fuel, Issue 1, DNV GL, 2014. https://www.dnvgl.com/maritime/lng/lng-as-ship-fuel-report.html. Sourced on 5 October 2018. See pages $16-17$.
} 

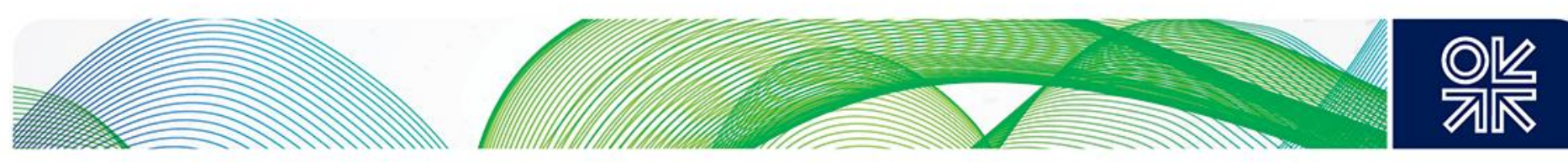

length of payback would depend on the amount of time that vessel would spend in an ECA, and its related levels of LSMGO and HFO consumption. Also, these calculations do not take into account vessel-specific factors, such as the amount of space available on board to host either a scrubber or LNG fuel tanks (which are larger than the fuel tanks needed for vessels running on oil-based fuels). For newbuild vessels operating in Northern Europe from 2021 onwards (as with newbuild vessels operating in the North American ECAs since 2016), the installation of a $\mathrm{NO}_{x}$ emissions abatement system alongside a scrubber would also take up valuable space on board a vessel running on oil-based fuel. Furthermore, to meet both $\mathrm{SO}_{x}$ and $\mathrm{NO}_{x}$ regulations in North America and Northern Europe, the cost of a newbuild LNG-fuelled vessel must be compared with the cost of a newbuild vessel with both a scrubber and a $\mathrm{NO}_{x}(\mathrm{SCR}$ or EGR) system.

While the expectations of bunker fuel prices post-2020 discussed above will inform the choices between LNG, scrubbers, and IMO-compliant fuel oil and gasoil, LNG will have a significant advantage in Northern Europe from 2021 onwards, given the restrictions on $\mathrm{NO}_{x}$ emissions from newbuild vessels. Assuming that fuel costs for LNG and fuel oil are similar, the fact that LNG is a priori compliant with Tier III $\mathrm{NO}_{x}$ emissions restrictions, as already seen in Norway and North America, is likely to be a significant factor for newbuilds in Northern Europe from 2021 onwards.

\section{Where does this leave the economic case for LNG?}

At present, vessels operating outside ECAs have little incentive to do anything other than continue consuming high-sulphur fuel oil. The case for LNG in the North Sea/Baltic Sea ECAs has been most compelling for newbuilds, based on the savings in fuel costs relative to LSMGO. The fact that, from 2021 onwards, newbuild vessels running on LNG will not require any additional investment to comply with $\mathrm{NO}_{x}$ emissions restrictions should further strengthen the case for LNG in those regions.

At a global level, from January 2020 onwards, the economic case for LNG will depend on the balance between the prices of IMO-compliant fuels, high-sulphur HFO, and LNG bunker fuel. With low-sulphur ( 0.5 per cent) fuel oil expected to be priced at only a small discount to LSMGO (0.1 per cent sulphur), and the price of high-sulphur HFO set to fall, LNG is likely to occupy a pricing 'middle ground' between the compliant and non-compliant oil-based fuels. If the premium of LNG over non-compliant fuel oil remains relatively modest, LNG could represent a commercially attractive path to achieving $\mathrm{SO}_{\mathrm{x}}$ and $\mathrm{NO}_{x}$ compliance, where the only major remaining concern for ship owners/operators is the physical availability of LNG bunker fuel at ports.

\section{LNG supplies in the North Sea and Baltic Sea region: Sources of LNG for bunkering}

\section{LNG supply chains}

While LNG may be a technically and commercially viable means of meeting emissions standards, ship owners/operators will not make LNG their bunker fuel of choice unless they are confident of its physical availability in commercial volumes. The provision of LNG as a bunker fuel is dependent on the development of supply chains. In the context of tightening restrictions on $\mathrm{SO}_{\mathrm{x}}$ emissions in the North Sea and Baltic Sea regions, the development of large-scale regional LNG import infrastructure as an alternative to pipeline imports, together with small-scale LNG import infrastructure in off-grid locations, have created a situation in which it has become commercially viable to invest in LNG bunkering services as the 'last mile' of the supply chain.

Working backwards up the supply chain, the provision of LNG as a bunker fuel is more commercially attractive if the provider does not have to pay to liquefy pipeline-supplied natural gas. However, this requires the availability of LNG. Given the relatively small volumes demanded by the early stages of market development for LNG as a bunker fuel, the provision of the necessary supplies is more commercially viable if there is already a supply of LNG that has been developed for another purpose - 

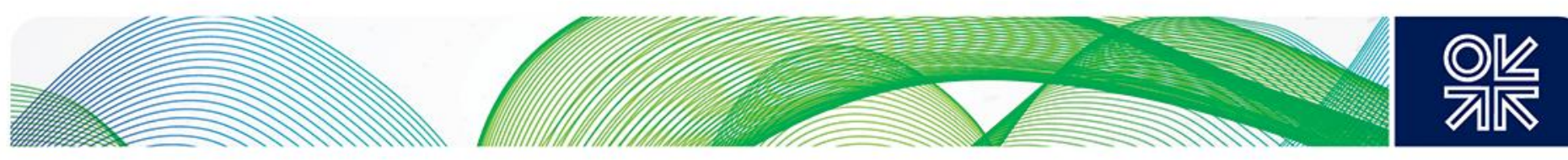

for a market that is already more developed. (Such a developed market would be the import of LNG for regasification and consumption in the power generation, industrial, and residential sectors.)

In the North Sea and Baltic Sea regions, the development of LNG import terminals has provided a ready supply of LNG that could be either offered as a bunker fuel at the terminal itself, or loaded onto trucks and delivered to nearby ports, where it could then be offered as a bunker fuel.

Finally, given that shipping costs for a single unit of any commodity are reduced as the size of the vessel carrying that commodity increases, the commercial viability of small-scale LNG shipments increases when the delivery distances are reduced. For example, it is not commercially viable to import smallscale LNG cargoes from Qatar to the North Sea/Baltic Sea region. However, it is commercially viable to import large-scale cargoes from Qatar to large-scale terminals in the North Sea/Baltic Sea region, and then break up and re-export those cargoes on a small scale to other terminals in the region.

In the North Sea and Baltic Sea regions, the small-scale supply of LNG has been dependent on the development of small-scale LNG exports from Norway, and the development of large-scale LNG import terminals that have the capacity to break up larger shipments of $L N G$ and then re-export them in smaller volumes to the small-scale LNG import terminals of the region. Furthermore, not only do some of the large-scale LNG import terminals provide the ability to bulk-break large-scale LNG shipments, they also enable the provision of bunkering and truck-loading services at the terminals themselves.

Therefore, the development of LNG exports from Norway, followed by the development of large-scale LNG import terminals across Northern Europe, have provided a base from which small-scale LNG terminals were developed. At these terminals, truck-loading facilitated the delivery of LNG supplies to ports, ultimately leading to the provision of LNG as a bunker fuel at both LNG terminals and ports, thus completing the supply chain.

\section{Early development of the North Sea/Baltic Sea LNG supply chain (2003-10)}

In terms of the chronology of these developments, the table in Appendix 2 highlights the fact that Norwegian LNG exports only began in 2003, and that, prior to 2005, the only LNG import terminal in the North Sea/Baltic Sea ECAs was a large-scale terminal at Zeebrugge in Belgium (launched in 1987). The French large-scale LNG import terminal at Montoir-de-Bretagne (launched in 1980) is located in western France (around $50 \mathrm{~km}$ from Nantes), just outside the North Sea ECA. (Locations of terminals in the North Sea/Baltic Sea ECAs are indicated in Figure 5.)

Between 2003 and 2010, infrastructure was developed in Norway for LNG exports, imports, and bunkering. Beyond the ECA, two terminals were launched in 2007: the Snøhvit large-scale LNG export terminal (capacity of 4.3 million tonnes per year), and the Mosjøen small-scale import terminal. Within the ECA, small-scale export terminals were launched at Snurrevarden $\left(20,000\right.$ tonnes $/ 44,440 \mathrm{~m}^{3}$ per year) and Kollsnes I (40,000 tonnes/88,880 $\mathrm{m}^{3}$ per year) in 2003 , and at Kollsnes II $(80,000$ tonnes $/ 177,760 \mathrm{~m}^{3}$ per year) in 2007. LNG bunkering was made available at all of these terminals. ${ }^{46,47}$

During that same period, the only other additions to regional LNG import capacity were in the UK: Isle of Grain inside the ECA (2005) and South Hook/Dragon outside the ECA (2009). By the end of 2010, Norwegian LNG exports had regional destination markets only in France (Montoir-de-Bretagne), Belgium (Zeebrugge), and the UK (Isle of Grain, South Hook, and Dragon).

\footnotetext{
${ }^{46}$ LNG map 2018, Gas Infrastructure Europe (GIE), 2017. https://www.gie.eu/download/maps/2017/GIE LNG 2018 A0 1189x841 FULL.pdf. Sourced on 26 June 2018. Map published in December 2017, with data accurate up to October 2017.

${ }^{47}$ One tonne of LNG equals $2.222 \mathrm{~m}^{3}$ of LNG. See: Natural gas conversion pocketbook, Oslo: International Gas Union (IGU), 2012. http://members.igu.org/old//GU\%20Events/wgc/wgc-2012/wgc-2012-proceedings/publications/igu-publications. See page 22.
} 

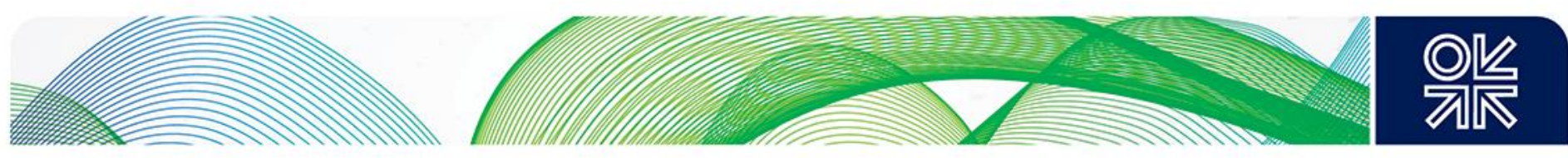

Therefore, in the North Sea/Baltic Sea ECAs, the development of large and small-scale LNG import infrastructure with the ability to perform re-exports, truck-loading, and bunkering, along with the provision of LNG bunkering services in commercial ports, has occurred largely since 2010.

\section{Development of the North Sea/Baltic Sea LNG supply chain since 2010}

\section{LNG terminals}

Since 2010, a further four large-scale LNG import terminals have been constructed in the Netherlands (Gate Rotterdam, 2011), Lithuania (Klaipeda, 2014), France (Dunkerque, 2016), and Poland (Swinoujscie, 2016), complementing the existing Zeebrugge and Isle of Grain terminals and bringing the total number of large-scale LNG import terminals in the North Sea/Baltic Sea ECAs to six (plus Montoir-de-Bretagne and South Hook/Dragon proximate to the North Sea ECA). In Norway, the Risavika LNG export terminal near Stavanger was launched in 2011 with an annual export capacity of 300,000 tonnes $\left(666,600 \mathrm{~m}^{3}\right)$ of LNG. With the Snøhvit LNG export terminal focused on large-scale LNG exports, the opening of the Risavika terminal provided a substantial source of small-scale supplies to the North Sea/Baltic Sea regional LNG market, with an export capacity more than double that of the Snurrevarden and Kollsnes I \& II terminals combined. ${ }^{48}$ This brought Norway's annual small-scale LNG export capacity to 440,000 tonnes $\left(977,680 \mathrm{~m}^{3}\right)$, equivalent to 598 million cubic metres of natural gas.

The launch of small-scale LNG reloading operations at Zeebrugge $\left(7,000 \mathrm{~m}^{3}\right.$ per cargo since 2010 and $2,000 \mathrm{~m}^{3}$ per cargo since 2015), Gate Rotterdam (5,000 $\mathrm{m}^{3}$ since 2013 and $500 \mathrm{~m}^{3}$ since 2016), Klaipeda (5,000 $\mathrm{m}^{3}$ since 2017), and Dunkerque $\left(5,000 \mathrm{~m}^{3}\right.$ since 2018), offered further small-scale LNG supplies to the growing market. The smaller the minimum cargo size, the more flexible the commercial operations. Such services are planned for the Isle of Grain (1,000 $\mathrm{m}^{3}$ planned from 2020). In December 2017, Skangas signed a letter of intent with National Grid Grain LNG, to develop facilities for breaking up large LNG cargoes and re-loading them onto small-scale LNG carriers ('break bulk'). The Skangas press release noted that 'the small-scale market is rapidly developing' and that the capacity of its Risavika plant in Norway had 'already been exceeded', leading Skangas to source LNG elsewhere.49 At the time of writing, the proposed break bulk services have not yet been launched at the Isle of Grain. These services are currently not available (or planned) at Swinoujscie. Close to the North Sea ECA, the Montoir-de-Bretagne LNG import terminal offers reloads of vessels with carrying capacities of $20,000 \mathrm{~m}^{3}$ or larger, while the Dragon/South Hook terminals in the UK do not offer this service. $50,51,52$ Such reloads require the LNG to be unloaded from the first vessel, stored in the terminal's onshore storage tank, and then reloaded onto a second vessel.

Trans-shipment enables the direct transfer of LNG from one vessel to another, including from a largescale LNG carrier to a small-scale LNG carrier. The minimum size of vessel that can receive such transshipments varies by terminal: Montoir-de-Bretagne $\left(20,000 \mathrm{~m}^{3}\right.$ since 2013$)$, Isle of Grain $\left(70,000 \mathrm{~m}^{3}\right.$ since 2014), Gate Rotterdam (5,000 $\mathrm{m}^{3}$ since 2015), and Zeebrugge (2,000 $\mathrm{m}^{3}$ since 2016). Such services are not available at Dunkerque, Swinoujscie, Klaipeda, or Dragon/South Hook.

\footnotetext{
${ }^{48}$ Skangas liquefaction plant, Risavika, Skangas, 2018. https://www.skangas.com/supply-chain/terminals--plants/liquefactionplant-risavikal. Sourced on 26 June 2018.

49 'Skangas signs Letter of Intent with National Grid Grain LNG', Press release, Skangas, 12 December 2017. https://www.skangas.com/skangas/news/2017/skangas-signs-letter-of-intent-with-national-grid-grain-Ing/. Sourced on 26 June 2018.

${ }^{50}$ GLE new LNG services inventory, GLE, 2018. https://www.gie.eu/index.php/gie-publications/databases/gle-Ing-servicesinventory. Sourced on 29 August 2018.

51 'Developing the Zeebrugge LNG terminal into an international hub for large-scale as well as small-scale LNG', Verhaeghe, P., Gastech Conference Presentation (April 2017). https://docplayer.net/52952629-Developing-the-zeebrugge-Ing-terminal-intoan-international-hub-for-large-scale-as-well-as-small-scale-Ing-gastech-4-7-april-2017.html. Sourced on 29 August 2018.

52 'Klaipedda LNG terminal receives the 50th cargo', Press release, Klaipeda Nafta, 25 May 2018. https://www.kn.It/en/news/news/klaipeda-Ing-terminal-receives-the-50th-cargo/2431. Sourced on 29 August 2018.
} 

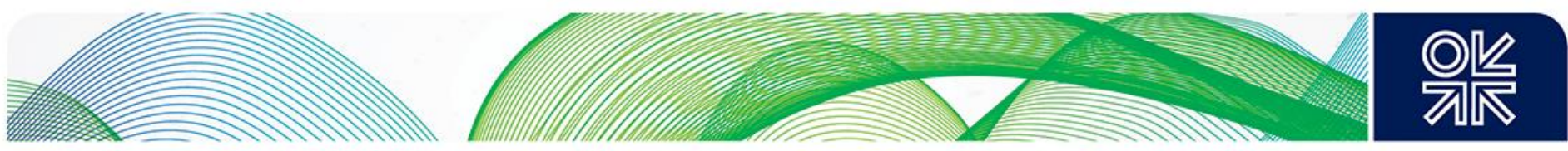

On the receiving side, five small-scale LNG import terminals have been launched in the region since 2011. One of these is in Norway (Øra Fredrikstad in 2011), two are in Sweden (Nynäshamn in 2011 and Lysekil in 2014), and two are in Finland (Pori in 2016 and Tornio Manga in 2018). Therefore, there are now 14 LNG terminals in the North Sea/Baltic Sea ECAs, comprising six large-scale and five smallscale import terminals, and three small-scale Norwegian export terminals.

\section{Figure 5: LNG import and export terminals in the North Sea/Baltic Sea ECAs}

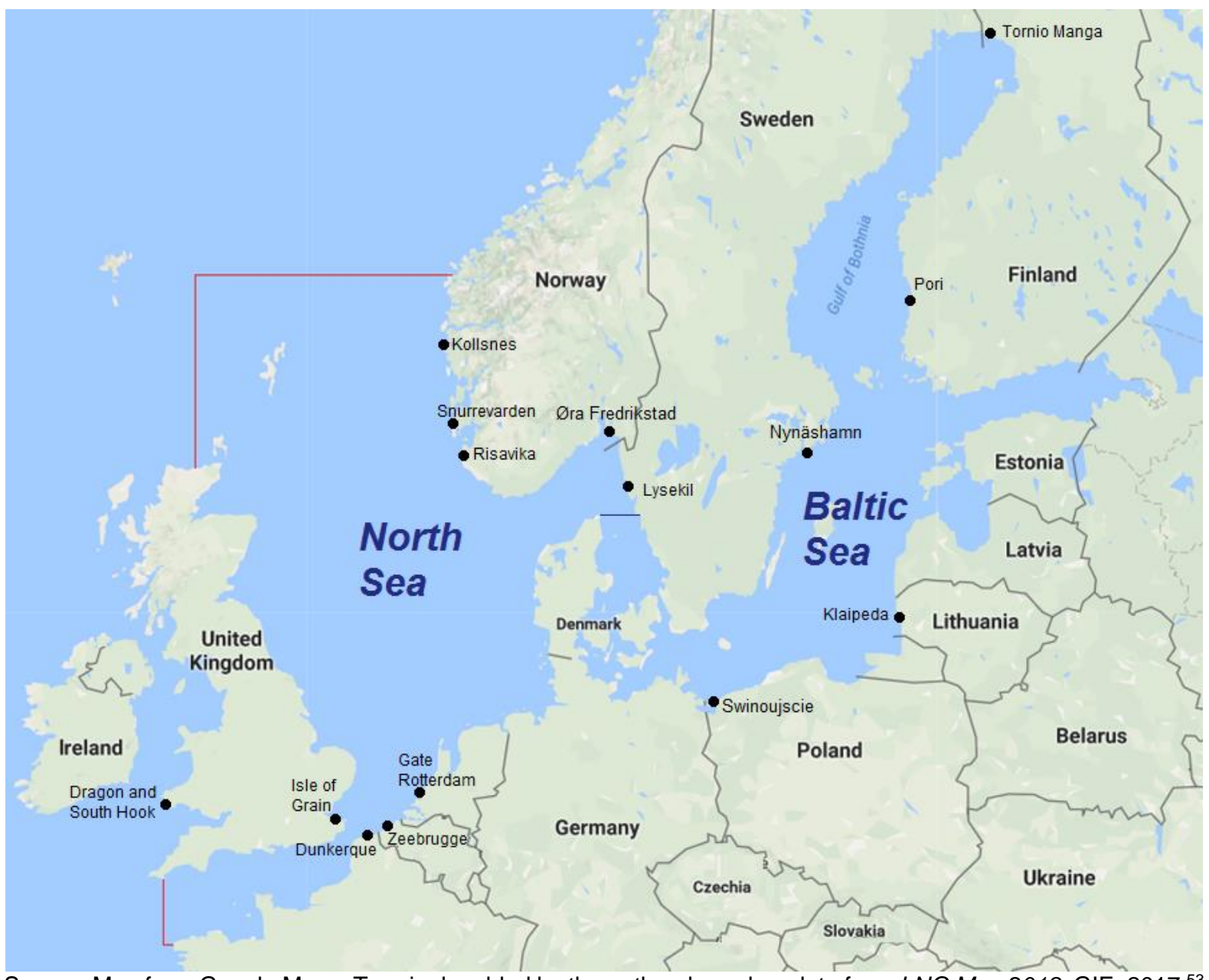

Source: Map from Google Maps. Terminals added by the author, based on data from LNG Map 2018, GIE, 2017.53

Size matters, because the small-scale LNG import terminals can only receive vessels up to certain capacities. For example, the large-scale import terminals at Dunkerque, Zeebrugge, Rotterdam, and the Isle of Grain can receive vessels of sizes up to $266,000-267,000 \mathrm{~m}^{3}$ of LNG, while the terminals at Swinoujscie $\left(216,000 \mathrm{~m}^{3}\right)$ and Klaipeda $\left(160,000 \mathrm{~m}^{3}\right)$ can receive slightly smaller vessels.

By contrast, the small-scale LNG import terminals at Nynäshamn $\left(15,000 \mathrm{~m}^{3}\right)$ and Pori $\left(20,000 \mathrm{~m}^{3}\right)$ can only receive small-scale $L N G$ carriers. ${ }^{54}$ Data for the maximum size of vessel that can be received at the Skangas-owned terminals at Tornio Manga and Øra Fredrikstad is not given by GIE, but Skangas state that LNG will be delivered to Tornio on an $18,000 \mathrm{~m}^{3}$ capacity vessel, and that vessels with 

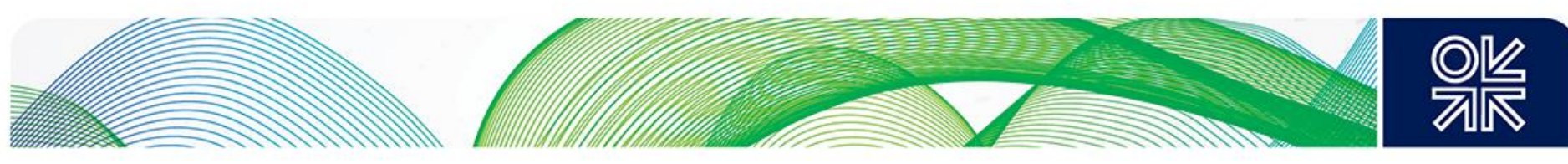

capacities of 7,000-15,000 $\mathrm{m}^{3}$ deliver LNG to Øra Fredrikstad. ${ }^{55,56}$ Skangas has not provided data on the maximum vessel size receivable at its Lysekil terminal in Sweden. ${ }^{57}$

The launch dates for these services are important, because they highlight the extent to which the process of receiving a large-scale LNG cargo into the North Sea/Baltic Sea region, breaking it up, and re-exporting a portion of that cargo as a small-scale LNG delivery to one of the region's small-scale import terminals, has been possible only in recent years. Therefore, the supply of small-scale LNG to the region has come in waves:

a) From the Snurrevarden and Kollsnes terminals in Norway since 2003/2007;

b) From the Risavika terminal in Norway since 2011, and

c) As small-scale reloads from Zeebrugge (2010), Rotterdam (since 2013), Klaipeda (2017), and Dunkerque (2018).

These waves of small-scale supplies correlated with the opening of five new small-scale LNG import terminals in the region between 2011 and 2018, as noted above.

\section{Truck loading facilities}

The final step in completing the LNG supply chain (see Figure 6) was to enable the loading of LNG onto trucks, for onward distribution. This not only facilitates the delivery of LNG to power stations and industrial consumers in off-grid locations, but also the delivery of LNG to satellite storage locations, where it can be loaded onto road vehicles as a transportation fuel.

However, for the purpose of this paper, the most important point to note is that truck-loading at LNG terminals enables the delivery of LNG to ports for loading onto ships as a bunker fuel, particularly for truck-to-ship bunkering. This may be in locations where, despite the availability of pipeline gas supplies, the close proximity of an LNG terminal with truck-loading capabilities means that it is more cost effective for ports to source LNG in its liquid form in small volumes on trucks than it is to invest in the infrastructure necessary to liquefy pipeline gas. The ongoing operational costs of such liquefaction would also add to the price at which the LNG would be made available as a bunker fuel. Truck-loading also enables the delivery of LNG to off-grid locations, where the liquefaction of pipeline gas is not possible. Stockholm is one example of an off-grid port that hosts LNG bunkering operations. ${ }^{58}$

Such truck-loading operations are now possible at all five of the large-scale LNG terminals in the North Sea/Baltic Sea region: Zeebrugge (since 2010), Gate Rotterdam (since 2014), Isle of Grain (since 2015), Swinoujscie (since 2016), and Klaipeda (since 2017), while such services are planned at Dunkerque from the end of $2018 .{ }^{59,60}$ Truck-loading services have been available at the region's five

\footnotetext{
${ }^{55}$ Manga Terminal, Tornio, Skangas, 2018. https://www.skangas.com/supply-chain/terminals--plants/skangas-terminal-tornio/. Sourced on 13 July 2018.

56 Skangas Terminal, Øra, Skangas, 2018. https://www.skangas.com/supply-chain/terminals--plants/skangas-terminal-ora/. Sourced on 13 July 2018.

${ }^{57}$ Skangas Terminal, Lysekil, Skangas, 2018. https://www.skangas.com/supply-chain/terminals--plants/skangas-terminallysekil/. Sourced on 13 July 2018.

58 The European natural gas network 2017, ENTSOG, 2017. https://www.entsog.eu/public/uploads/files/publications/Maps/2017/ENTSOG CAP 2017 A0 1189x841 FULL 064.pdf. Sourced on 13 July 2018.

${ }^{59}$ GLE new LNG services inventory, GLE, 2018, op. cit.

60 'First LNG truck loading in Zeebrugge', Press release, Fluxys, 19 November 2010.

https://www.fluxys.com/belgium/en/newsandpress/2010/101119 truckloading.aspx. Sourced on 29 August 2018.
} 

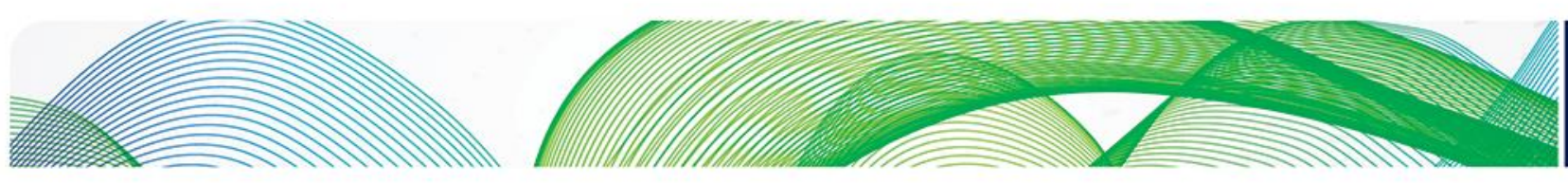

small-scale import terminals - Øra Fredrikstad (2011), Nynäshamn (2011), Lysekil (2014), Pori (2016), and Tornio (2018) - since the terminals were launched. ${ }^{61}$

\section{Figure 6: Schematic representation of the different LNG bunkering practices}

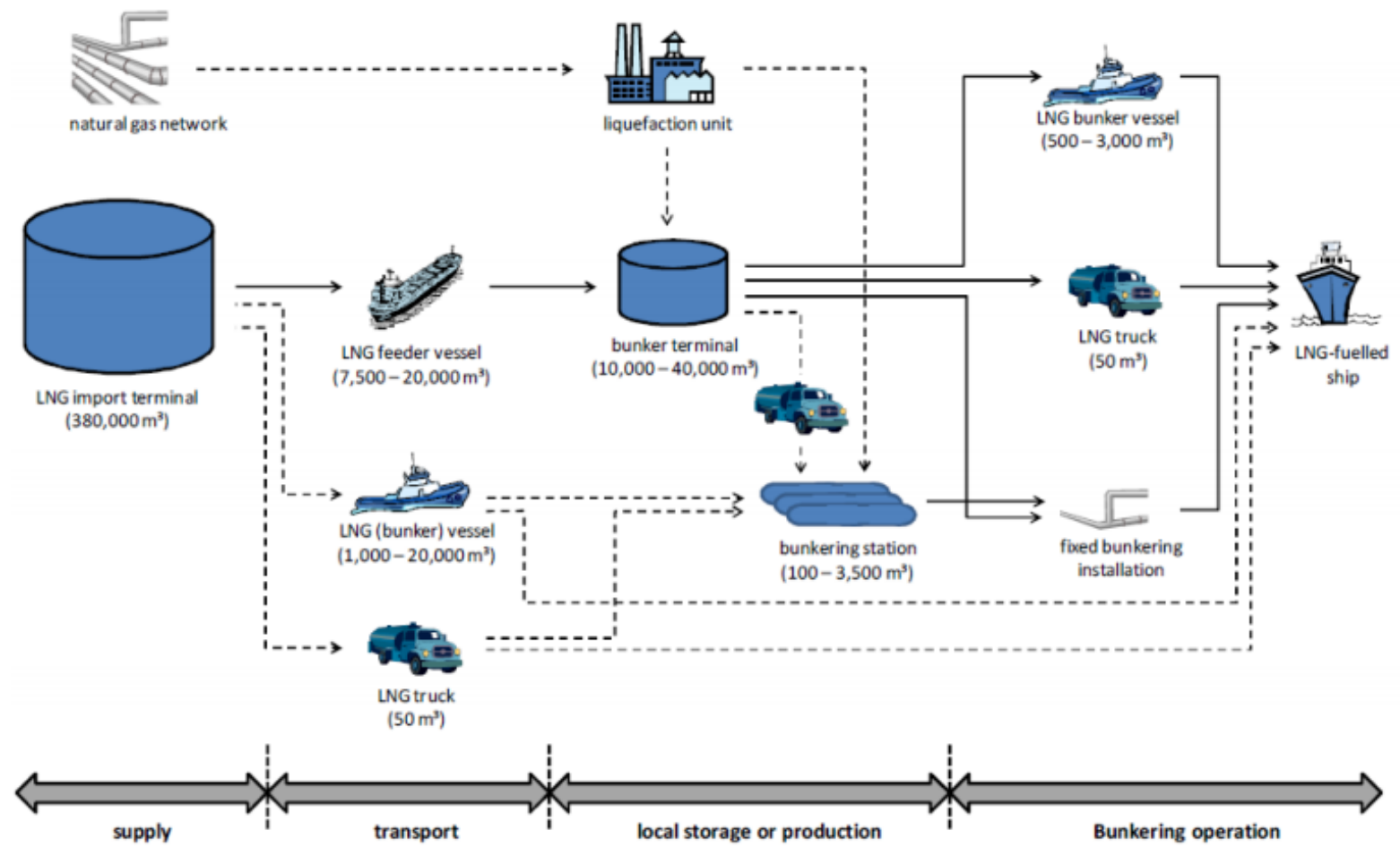

Source: Guidance on LNG bunkering to port authorities and administrations, EMSA, 2018.62

\section{LNG bunkering facilities}

Based on this infrastructure, the provision of LNG bunkering has been made available in 16 Norwegian ports (nine within and seven beyond the North Sea ECA) since 2003. ${ }^{63}$ LNG bunkering has also been made available in 16 non-Norwegian ports in the North Sea/Baltic Sea ECAs since 2011.64 The different types of bunkering suitable for vessels of different sizes are given in Figure 7, while locations of the terminals and ports that provide LNG bunkering are illustrated in Figure 8.

${ }^{61}$ GIE SSLNG database, Gas Infrastructure Europe (GIE), 2018.

www.gie.eu/maps data/downloads/2018/20180124 SSLNG database FINAL out.xlsx. Sourced on 1 June 2018. Published in February 2018, with data up to January 2018

${ }^{62}$ Guidance on LNG bunkering to port authorities and administrations, Lisbon: EMSA, European Maritime Safety Agency (EMSA), 2018. (See page 42). https://safety4sea.com/wp-content/uploads/2018/02/EMSA-Guidance-on-LNG-Bunkering-toPort-Authorities-and-Administrations-2018 02.pdf. Sourced on 4 October 2018.

${ }^{63}$ Ports: Florø, Haugesund, Ågotnes, Avaldsnes, Bergen, Hordvikneset, Stavanger, Haukås, and Øs inside the North Sea ECA, and Melkøya Island (Hammerfest), Bodø, Kirkenes, Kristiansund, Lødingen, Moskenes, and Sandnessjøen outside the ECA. ${ }^{64}$ Ports: Antwerp (Belgium); Amsterdam and Moerdijk (Netherlands); Brünsbuttel, Rostock, Hamburg, Bremen, Cuxhaven, and Emden (Germany); Hirtshals and Copenhagen-Malmö (Denmark); Tallinn (Estonia); Helsinki (Finland); Stockholm and Gothenburg (Sweden); and Immingham (UK). 

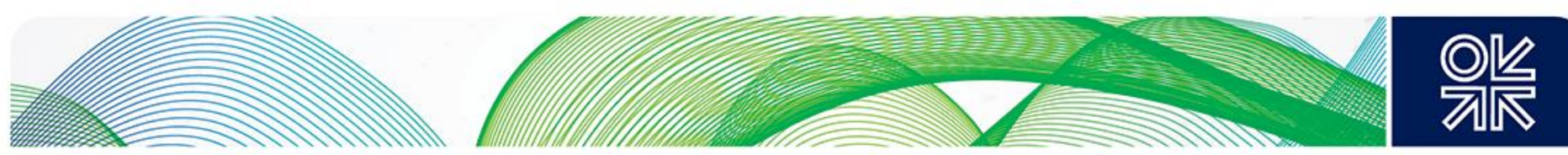

Figure 7: Typical LNG bunkering by different generic ship type

\begin{tabular}{|c|c|c|c|c|c|}
\hline $\begin{array}{l}\text { Vessel Type } \\
\text { (Recelving vessel) }\end{array}$ & $\begin{array}{l}\text { Bunker } \\
\text { Quantity }\end{array}$ & Rate & Duration & $\begin{array}{l}\text { Hoses or arm } \\
\text { diameter }\end{array}$ & $\begin{array}{c}\text { Adequate } \\
\text { Bunkering } \\
\text { Mode }\end{array}$ \\
\hline $\begin{array}{l}\text { Service vessels, } \\
\text { tugboats, patrol } \\
\text { boats and fishing } \\
\text { boats }\end{array}$ & $50 \mathrm{~m}^{3}$ & $60 \mathrm{~m}^{3} / \mathrm{h}$ & $45 \mathrm{~min}$ & $2 \times 2^{\prime \prime}$ or $1 \times 3^{\prime \prime}$ & TTS \\
\hline $\begin{array}{l}\text { Small Ro-Ro and Ro- } \\
\text { Pax vessels }\end{array}$ & $400 \mathrm{~m}^{3}$ & $400 \mathrm{~m}^{3} / \mathrm{h}$ & $1 \mathrm{hr}$ & $2 \times 4^{\prime \prime}$ or $1 \times 6^{\prime \prime}$ & TTS/STS \\
\hline $\begin{array}{l}\text { Large Ro-Ro and Ro- } \\
\text { Pax vessels }\end{array}$ & $800 \mathrm{~m}^{3}$ & $400 \mathrm{~m}^{3} / \mathrm{h}$ & $2 \mathrm{hr}$ & $2 \times 4^{\prime \prime}$ or $1 \times 66^{\prime \prime}$ & STS \\
\hline $\begin{array}{l}\text { Small cargo, } \\
\text { container and freight } \\
\text { vessels }\end{array}$ & $\begin{array}{c}2,000-3,000 \\
m^{3}\end{array}$ & $1,000 \mathrm{~m}^{3} / \mathrm{h}$ & 2 to $3 \mathrm{hr}$ & $2 \times 8^{\prime \prime}$ or $1 \times 12^{\prime \prime}$ & STS \\
\hline Large freight vessels & $4,000 \mathrm{~m}^{3}$ & $1,000 \mathrm{~m}^{3} / \mathrm{h}$ & $4 \mathrm{hr}$ & $2 \times 8^{\prime \prime}$ or $1 \times 12^{\prime \prime}$ & STS \\
\hline $\begin{array}{l}\text { Large tankers, bulk } \\
\text { carriers and } \\
\text { container ships }\end{array}$ & $10,000 \mathrm{~m}^{3}$ & $2,500 \mathrm{~m}^{3} / \mathrm{h}$ & $4 \mathrm{hr}$ & $2 \times 10^{\prime \prime}$ & STS/ PTS \\
\hline $\begin{array}{l}\text { Very large container } \\
\text { ships and oil tankers }\end{array}$ & $20,000 \mathrm{~m}^{3}$ & $3,000 \mathrm{~m}^{3} / \mathrm{h}$ & $7 \mathrm{hr}$ & $2 \times 12^{\prime \prime}$ & STS/ PTS \\
\hline
\end{tabular}

Source: Guidance on LNG bunkering to port authorities and administrations, EMSA, 2018. ${ }^{65}$

Key: Truck-to-Ship (TTS); Ship-to-Ship (STS); Port-to-Ship (PTS).

Of the nine Norwegian ports in the North Sea ECA with LNG bunkering, services were launched in four locations in 2003-04 and in four locations in 2009-12, while the launch date of LNG bunkering in the port of Øs is not confirmed. In the 16 non-Norwegian ports with LNG bunkering, six launched operations in 2011-14, and ten in 2015-18. In addition, LNG bunkering was launched at LNG terminals in Norway at Snurrevarden and Kollsnes I in 2003-04, at Kollsnes II and Risavika in 2007/2011, and at Øra Fredrikstad in 2014. Outside Norway, LNG bunkering operations were launched at LNG terminals in Rotterdam (2013), Pori (2016), Zeebrugge, Klaipeda, and Lysekil (2017). Such services are planned at Tornio (2018), Dunkerque (2019), and Swinoujscie (2021). ${ }^{66}$

\section{A complete LNG supply chain}

Given the foregoing discussion, it is clear that the market for small-scale LNG deliveries in the North Sea and Baltic Sea regions is a fundamentally recent development. Prior to 2011, Norwegian smallscale LNG exports were limited, and the few large-scale LNG import terminals that were operational in the region (Zeebrugge and Isle of Grain in the North Sea ECA, and Montoir-de-Bretagne and South Hook/Dragon proximate to the ECA) did not offer small-scale reloading/trans-shipment, truck-loading, or bunkering services. In short, the development of the LNG supply chain was limited.

Less than a decade later, small-scale LNG supplies may be sourced from Norwegian export terminals (primarily Risavika) and small-scale reloads at four large-scale LNG import terminals (Zeebrugge, Gate Rotterdam, Klaipeda, Dunkerque) inside the North Sea/Baltic Sea ECAs. These small-scale LNG supplies represent a new regional market. On the bunkering side, as well as the LNG bunkering services available at three large-scale import terminals (Zeebrugge, Gate Rotterdam, and Klaipeda) and three

\footnotetext{
${ }^{65}$ Guidance on LNG bunkering to port authorities and administrations, EMSA, 2018, op. cit. (See page 51.$)$

${ }^{66}$ See Appendix for details.
} 

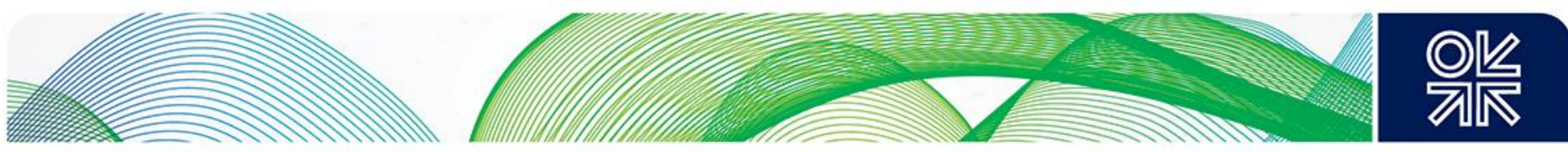

small-scale import terminals (Pori, Tornio, and Lysekil) outside Norway, services are also available at three Norwegian small-scale export terminals (Snurrevarden, Kollsnes, and Risavika) and one Norwegian small-scale import terminal (Øra Fredrikstad). In addition, widespread truck-loading at LNG terminals means that ships may now take on LNG as a bunker fuel in nine Norwegian and 16 nonNorwegian ports in the North Sea/Baltic Sea ECAs. This means that ships may now take on LNG as a bunker fuel in 35 locations in the North Sea/Baltic Sea ECAs, as illustrated in Figure 8.

\section{Figure 8: Existing LNG bunkering facilities in the North Sea/Baltic Sea ECAs}

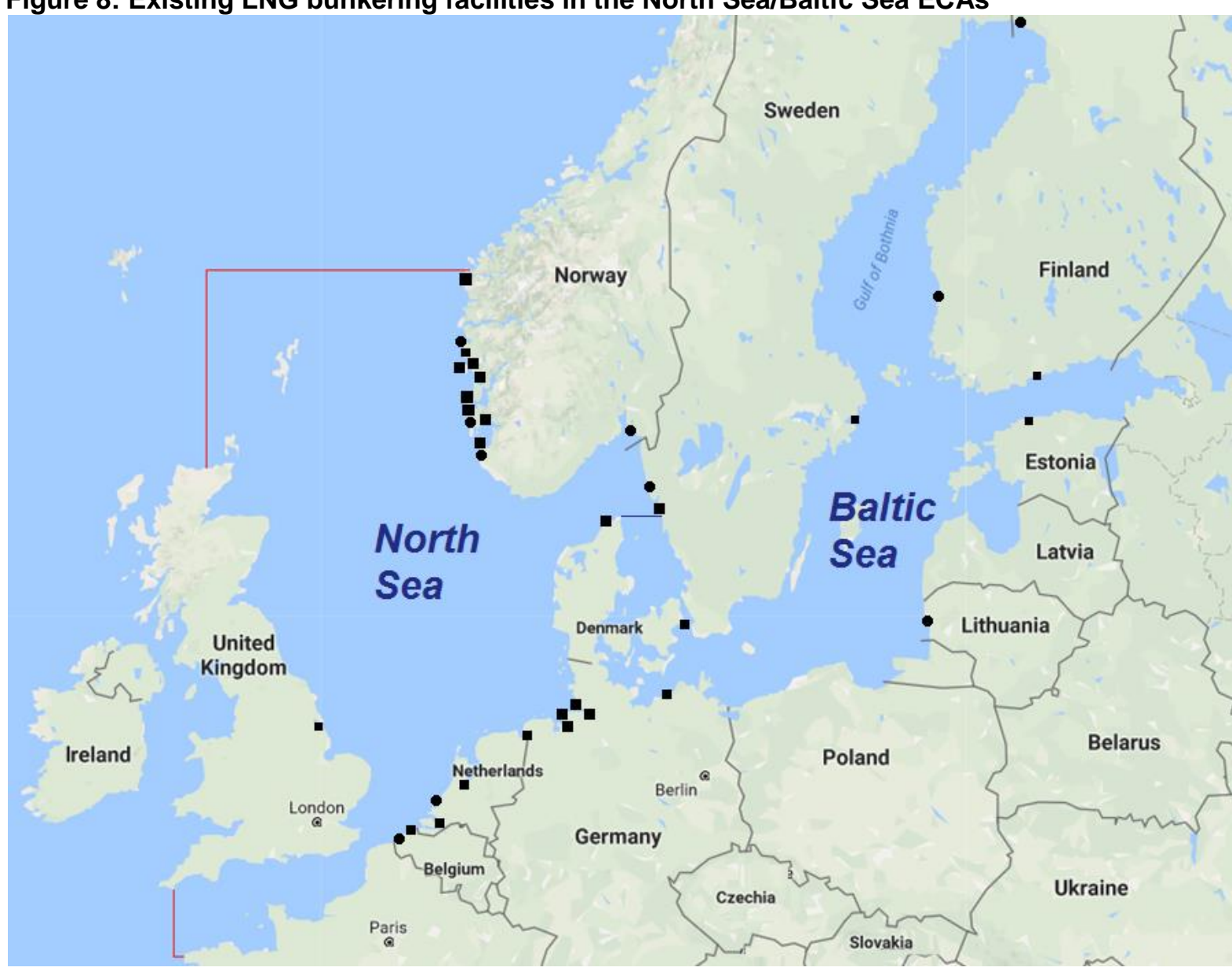

Source: Map created by the author using data from Gas Infrastructure Europe. ${ }^{67,68}$

Note: LNG terminals with bunkering facilities are depicted as circles, while ports with LNG bunkering facilities are depicted as squares. The LNG terminals without LNG bunkering facilities are Dragon/South Hook, Isle of Grain, Dunkerque, and Nynäshamn.

Furthermore, the chronology of these developments shows that the establishment of LNG bunkering infrastructure in the region occurred in two notable waves. In Norway, the initial developments in 200304 were surpassed by a larger wave in 2007-11. Outside Norway, in the North Sea/Baltic Sea ECAs, the initial developments in 2011-14 were surpassed by a larger wave in 2015-18. In Norway, the larger wave of development coincided with the introduction of restrictions on $\mathrm{NO}_{x}$ emissions from shipping (2007/08). Outside Norway, the initial developments occurred alongside the first tightening of 

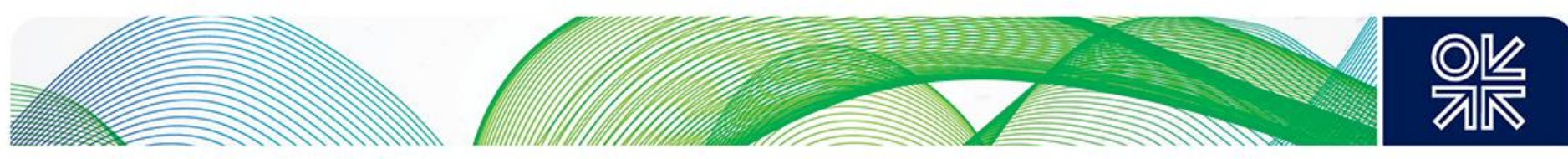

restrictions on shipping-sector $\mathrm{SO}_{x}$ emissions (2010), while the larger wave of development correlates with the second tightening of $\mathrm{SO}_{x}$ emissions restrictions (2015).

A 'third wave' of regulatory influence may be observed in the coming years: Article 6(1) of EU Directive 2014/94 states that Member states shall ensure that LNG refuelling points are available at all 'TEN-T Core Network' ports by the $31^{\text {st }}$ of December $2025 .{ }^{69}$ There are 22 such ports in the Baltic Sea ECA, 18 in the North Sea ECA, and a further 49 in the rest of the EU. ${ }^{70}$ At the same time, the forthcoming $\mathrm{NO}_{x}$ emissions restrictions for newbuilds in the North Sea/Baltic Sea from 2021 could further enhance the existing attractiveness of $L N G$ as a bunker fuel in that specific region, while the tightening of the restrictions on $\mathrm{SO}_{x}$ emissions beyond the ECAs in 2020 could spur wider demand for LNG bunker fuel.

\section{Market development: The regional LNG-propelled fleet}

\section{Small-scale LNG carriers and bunker vessels}

In addition to the development of regional LNG terminal infrastructure, the growth in the number of LNG carrier vessels capable of delivering LNG to those terminals has played a key role in market development. According to the International Group of Liquefied Natural Gas Importers (GIIGNL), the global fleet of LNG carriers stood at 511 at the end of 2017; this figure included 28 small-scale LNG carriers with a carrying capacity of $25,000 \mathrm{~m}^{3}$ of LNG or less. ${ }^{71}$ As a reminder, the maximum size of vessel that can supply the small-scale terminals of the North Sea/Baltic Sea region is $15,000-20,000 \mathrm{~m}^{3}$ of LNG.

Of the 28 small-scale LNG carriers identified by GIIGNL in its global fleet list, 15 operate outside the North Sea/Baltic Sea region, primarily in the Asia-Pacific. This leaves 13 small-scale LNG carriers that operate in the North Sea/Baltic Sea region. Of these vessels, four are multigas ${ }^{72}$ carriers owned by Teekay LNG and operated by Norgas (a subsidiary of I.M. Skaugen). A fifth, the Teekay-owned Norgas Unikum, listed by GIIGNL, now operates under the name Unikum Spirit. ${ }^{73}$ Crucially, the ability to carry different types of gases means that, although they are capable of carrying LNG, these five vessels do not always do so. ${ }^{74,75}$ Furthermore, there are three more small-scale LNG carriers owned by Anthony Veder and chartered by stakeholders in the regional small-scale LNG market: The Coral Methane, Coral Energy, and Coral Anthelia. ${ }^{76,77}$

There are also vessels that are used primarily for ship-to-ship LNG bunkering, but are still classed as small-scale LNG carriers. The Pioneer Knutsen, launched in 2004 with a capacity of just $1,100 \mathrm{~m}^{3}$, performs small-scale LNG deliveries and ship-to-ship LNG bunkering along the Norwegian coast. ${ }^{78}$ The world's first dedicated LNG bunker vessel (a converted ferry), the Seagas, has a small capacity of

\footnotetext{
${ }^{69}$ Directive 2014/94/EU of the European Parliament and of the Council of 22 October 2014 on the deployment of alternative fuels infrastructure. https://eur-lex.europa.eu/legal-content/EN/TXT/?uri=CELEX\%3A32014L0094\#ntr12L 2014307EN.01000101-E0012. Sourced on 31 August 2018.

${ }^{70}$ Comprehensive and core networks: Inland waterways and ports, European Commission, 2017. http://ec.europa.eu/transport/infrastructure/tentec/tentecportal/site/maps upload/tent modes/EU A0Landscape2017 iwws.png. Sourced on 31 August 2018.

GIIGNL 2018 annual report, GIIGNL, 2018. https://giignl.org/publications. Sourced on 9 July 2018. See page 15.

72 Multigas carriers are capable of carrying different types of liquefied gases and petrochemicals, such as liquefied petroleum gas (LPG), liquefied ethylene, and liquefied natural gas (LNG).

${ }^{73}$ Fleet list, Teekay, August 2018. https://www.teekay.com/about-us/fleet/. Sourced on 10 September 2018

${ }^{74}$ Norgas Creation (10,030 $\left.\mathrm{m}^{3}-2010\right)$, Norgas Innovation (10,030 $\left.\mathrm{m}^{3}-2010\right)$, Norgas Conception $\left(10,030 \mathrm{~m}^{3}-2011\right)$, Norgas $^{2}$ Invention (10,030 $\left.\mathrm{m}^{3}-2011\right)$, Norgas Unikum $\left(12,000 \mathrm{~m}^{3}-2011\right)$.

75 Our fleet, Norgas, 2018. https://norgascarriers.com/norgas-carriers/our-fleet/. Sourced on 3 October 2018.

${ }^{76}$ Coral Methane $\left(7,500 \mathrm{~m}^{3}-2009\right)$, Coral Energy $\left(15,600 \mathrm{~m}^{3}-2012\right)$, Coral Anthelia $\left(6,500 \mathrm{~m}^{3}-2013\right)$.

77 The fleet, Anthony Veder, 2018. https://www.anthonyveder.com/fleet/. Sourced on 12 July 2018.

${ }^{78}$ LNG carriers, Knutsen OAS Shipping, 2018. https://knutsenoas.com/shipping/lng-carriers/. Sourced on 12 July 2018.
} 

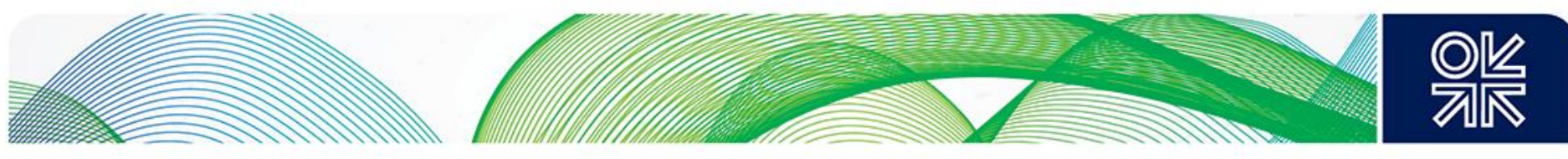

just $170 \mathrm{~m}^{3}$. The Seagas receives LNG from the Nynäshamn LNG Terminal and has performed bunkering operations for the Viking Grace LNG-fuelled ferry in the port of Stockholm since 2013. ${ }^{79}$

The year 2017 saw the launch of three purpose-built LNG bunkering vessels with much larger capacities: the Coralius $\left(5,737 \mathrm{~m}^{3}\right)$, Cardissa $\left(6,469 \mathrm{~m}^{3}\right)$, and ENGIE Zeebrugge $\left(5,100 \mathrm{~m}^{3}\right)$. The ENGIE Zeebrugge, has performed its bunkering only in Zeebrugge, since June 2017.80 By contrast, the Shell-chartered Cardissa and Skangas-chartered Coralius travel across the North Sea/Baltic Sea region from their bases at Rotterdam and Risavika (respectively) to load and perform bunkering operations. ${ }^{81,82}$ In November 2017, Anthony Veder and Shell agreed to modify the Coral Methane, to enable it to perform ship-to-ship LNG bunkering, in addition to its LNG carrier duties. ${ }^{83}$

Together, the five multigas carriers, three Coral vessels, and five bunker vessels make up the 13 smallscale LNG carriers listed by GIIGNL. That list of grew to 14 with the launch of the $18,000 \mathrm{~m}^{3}$ capacity LNG carrier, Coral EnergICE, in January 2018, under the ownership of Anthony Veder and chartership of Skangas. ${ }^{84}$ Although based outside the North Sea ECA, it is also notable that the world's sixth dedicated LNG bunker vessel, Oizmendi, has a $600 \mathrm{~m}^{3}$ capacity and performed its first ship-to-ship bunkering operation in the Port of Bilbao in February 2018. ${ }^{85}$ Then, in November 2018, Babcock Schulte Energy announced that it had delivered a new, ice-class, 7,500 $\mathrm{m}^{3}$ capacity LNG bunker vessel - Kairos - to Blue LNG, a 90/10 joint venture between Bomin Linde LNG and Klaipeda Nafta. ${ }^{86}$ The vessel will be based at the Klaipeda LNG terminal in Lithuania, and takes the number of LNG carriers and bunker vessels in the North Sea/Baltic Sea region to $15 .{ }^{87}$

Furthermore, Titan LNG is expecting the imminent delivery of a $1,480 \mathrm{~m}^{3}$ capacity bunker barge FlexFueler 1 - for operation in the Port of Amsterdam. ${ }^{88}$ On a much larger scale, by 2020 Total expects to receive an $18,600 \mathrm{~m}^{3}$ capacity bunker vessel to supply the nine LNG-fuelled container ships on order for the French shipping company, CMA CGM. Each of those container ships will have an LNG bunker tank equal in size to the capacity of the new bunker vessel. 89 In October 2018, Eesti Gaas announced that it had ordered a 6,000 $\mathrm{m}^{3}$ capacity LNG bunker vessel for delivery in September 2020. That vessel

\footnotetext{
79 'Stockholm offers vessel-to-vessel LNG bunkering', Marine Log, 29 March 2012.

https://www.marinelog.com/index.php?option=com k2\&view=item\&id=3819:stockholm-offers-vessel-to-vessel-Ingbunkering\&ltemid=1. Sourced on 12 July 2018.

80 'Ship-to-ship LNG bunkering service started in the port of Zeebrugge', Press release, Gas4Sea, 16 June 2017 http://www.gas4sea.com/news/ship-to-ship-Ing-bunkering-service-started-in-the-port-of-zeebrugge/.

1 'Shell starts operating hyper-modern LNG bunker vessel', Press release, Port of Rotterdam, 14 August 2017. https://www.portofrotterdam.com/en/news-and-press-releases/shell-starts-operating-hyper-modern-Ing-bunker-vessel. Sourced on 12 July 2018.

82 'Coralius' maiden trip', Press release, Skangas, 18 September 2017. https://www.skangas.com/skangas/news/2017/coraliusmaiden-trip/. Sourced on 12 July 2018.

${ }^{83}$ 'Shell and Anthony Veder to modify coral methane to LNG bunker vessel', Press release, Anthony Veder, 17 November

2017. https://www.anthonyveder.com/modification-coral-methane-to-Ing-bunker-vessel/. Sourced on 12 July 2018.

84 'Coral EnergICE, first Ice Class 1A Super LNG carrier named', Press release, Skangas, 25 January 2018.

https://www.skangas.com/skangas/news/2018/coral-energice-first-ice-class-1a-super-Ing-carrier-named/. Sourced on 12 July 2018.

85 'First STS LNG bunkering operation for Spain's Bilbao port', LNG World News, 5 February 2018.

https://www.Ingworldnews.com/first-sts-Ing-bunkering-operation-for-spains-bilbao-port/. Sourced on 12 July 2018.

86 'Babcock Schulte Energy delivers world's largest LNG Bunker Supply Vessel 'M.V. KAIROS”. Press release, Bernhard Schulte Ship Management, 2 November 2018. https://www.bs-shipmanagement.com/en/media/press-release-babcock-schulteenergy-delivers-world-s-largest-Ing-bunker-supply-vessel-\%E2\%80\%98m-v-kairos

87 'Bernhard Schulte Ship Management: a strategy for growth', Jallal, C., LNG World Shipping, 6 March 2018. www.Ingworldshipping.com/news/view, bernhard-schulte-shipmanagement-a-strategy-for-growth 51001 .htm. Sourced on 12 July 2018

88 'Tool for making LNG bunkering safe and sustainable', Press Release, Port of Amsterdam, 1 October 2018. https://www.portofamsterdam.com/en/news-item/tool-making-Ing-bunkering-safe-and-sustainable. Sourced on 10 January 2019.

89 'LNG bunker vessels: fleet review', Corkhill, M., LNG World Shipping, 9 August 2018.

https://www.Ingworldshipping.com/news/view,Ing-bunker-vessels-fleet-review 53852.htm. Sourced on 18 September 2018
} 

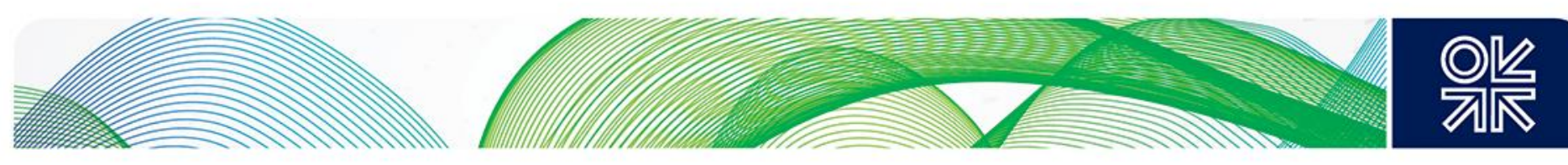

will take on LNG and perform bunkering at various locations in the Baltic region, and will replace the current truck-to-ship bunkering of the Tallink Megastar LNG-fuelled ferry in Tallinn. ${ }^{90}$ Finally, in December 2018, Keppel signed a contract to build an ice-class bunker vessel for operation by the Gazprom Neft subsidiary, Gazpromneft Marine Bunker Ltd, in the Baltic Sea from Q4 2020. ${ }^{91}$ Beyond the ECAs, Stolt-Neilsen has two $7,500 \mathrm{~m}^{3}$ capacity LNG bunker vessels on order for operation in Northern Europe (Scotland) and the Mediterranean Sea (Sardinia) from 2019.92

The information discussed above highlights two important points:

- The 15-strong fleet operational in the North Sea/Baltic Sea is relatively small. It includes five multigas carriers (which often do not carry LNG), four dedicated LNG carriers, and six LNG bunker vessels.

- The fleet is young and grew in two waves - Following the launch of Pioneer Knutsen (2004) and Seagas (2013), eight were launched between 2009 and 2013, followed by five in 2017-18, with four more on order for the region in 2019-20.

There is a strong chronological correlation between the development of small-scale LNG infrastructure (small-scale terminals and small-scale reloads at large-scale terminals) and the development of the small-scale LNG carrier/bunker vessel fleet. This chronological correlation also applies to the growth of LNG bunkering facilities (truck-to-ship, ship-to-ship, and terminal-to-ship) at ports and LNG terminals, and the growth of the LNG-fuelled fleet operating in the region.

\section{LNG-fuelled vessels (excluding LNG carriers)}

While the LNG carrier vessels, LNG terminals, truck-loading facilities, and bunkering infrastructure represent the 'supply' side of the regional LNG bunker market, LNG-fuelled vessels represent the 'demand' side. The current size of the regional LNG-fuelled fleet and the number of LNG-fuelled vessels on order are indicators of current and future demand for LNG as a bunker fuel.

\section{Waves of growth in the LNG-fuelled fleet}

The 'first movers' in LNG propulsion were vessels based in Norway that operate in a relatively fixed geographical area, namely, ferries and service vessels. (The latter includes Platform Service Vessels (PSVs), tugs, harbour vessels, and patrol vessels.) Of the 35 LNG-fuelled vessels in operation by the end of 2012 (including 32 launched since 2006), all were based in Norway and just two were neither a passenger nor a service vessel: a retrofitted oil/chemical tanker re-launched in 2011 and a newbuild bulk (fishfeed) carrier launched in 2012.

The period 2013-14 saw the launch of 21 more LNG-propelled vessels. These included:

- Europe's first non-Norwegian LNG-fuelled ferry (the Finnish-flagged Viking Grace on the Turku-Stockholm route),

- Europe's first two LNG-fuelled gas carriers (tankers carrying gases other than LNG, operating in Northern Europe),

- the first four LNG-fuelled tugs (two each in Norway and China),

\footnotetext{
90 'Eesti Gaas places order for the first LNG bunker vessel for north-east Baltic Sea', Press Release, Eesti Gaas, 2 October 2018. https://www.gaas.ee/en/eesti-gaas-places-order-for-the-first-Ing-bunker-vessel-for-north-east-baltic-sea/. Sourced on 5 October 2018.

91 'Keppel secures marine contracts worth around \$\$300m', Press Release, Keppel Corp., 26 December 2018. http://www.kepcorp.com/en/news item.aspx?sid=8274. Sourced on 14 January 2018.

92 'Stolt-Nielsen orders two small-scale LNG ships with bunkering capabilities', Ship and Bunker, 24 May 2017. https://shipandbunker.com/news/world/259996-stolt-nielsen-orders-two-small-scale-Ing-ships-with-bunkering-capabilities. Sourced on 12 July 2018.
} 

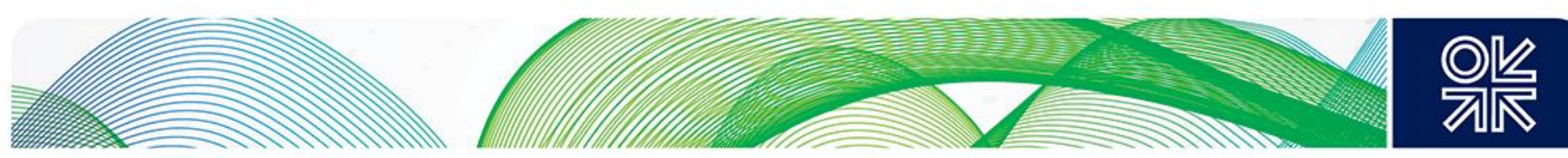

- the first two non-Norwegian harbour/patrol vessels (one each in Finland and South Korea), and

- South America's first LNG-fuelled ferry.

While the focus remained on vessels operating in geographically restricted areas, the tentative spread of LNG-fuelled shipping beyond Norway was notable. In the North Sea/Baltic Sea region specifically, 52 LNG-fuelled vessels were in operation by the end of 2014 (of which 46 were based in Norway), plus four outside Europe, giving a global total of 56 .

The period 2015-16 was a watershed for LNG shipping, with the cap on $\mathrm{SO}_{x}$ emissions from shipping in the North Sea, Baltic Sea, North American, and US Caribbean ECAs falling from 1.0 per cent to 0.1 per cent, and the Tier III NOx cap introduced for newbuilds in the North America/US Caribbean ECAs. That period saw the launch of 40 LNG-fuelled vessels, including the first icebreaker (Polaris in Finland), the first two bulk carriers, first two car carriers, the first two container ships, the first three roll-on, rolloff (ro-ro) cargo ships, and the first three newbuild oil/chemical tankers. This period also saw the launch of the first PSVs and ferries in the North American ECA. By the end of 2016, 73 LNG-fuelled vessels were operational in the North Sea/Baltic Sea region (including 56 in Norway and 17 beyond Norway), while the global LNG-fuelled fleet numbered 96, including eight in the North American/Caribbean ECAs, six in Asia, and six operating at a 'global' level, leaving three in other locations.

Finally, in 2017-18, 47 more LNG-fuelled vessels were launched, bringing the total in operation to 143. These new vessels include the world's first two LNG-fuelled dredgers (for operation in Northern Europe), the world's first retrofitted container ship (also for operation in Northern Europe), the world's first LNG-fuelled cruise ship (the Aida Nova), the first LNG-fuelled ferry to operate in the Mediterranean, and Asia's first LNG-fuelled cargo vessel. Figure 11 indicates the proportion of vessels of different classes with LNG propulsion in Norway and the North Sea/Baltic Sea region, both currently in operation and 'on order'.

Figure 9: Global fleet of LNG-fuelled vessels by location (number of vessels in operation)

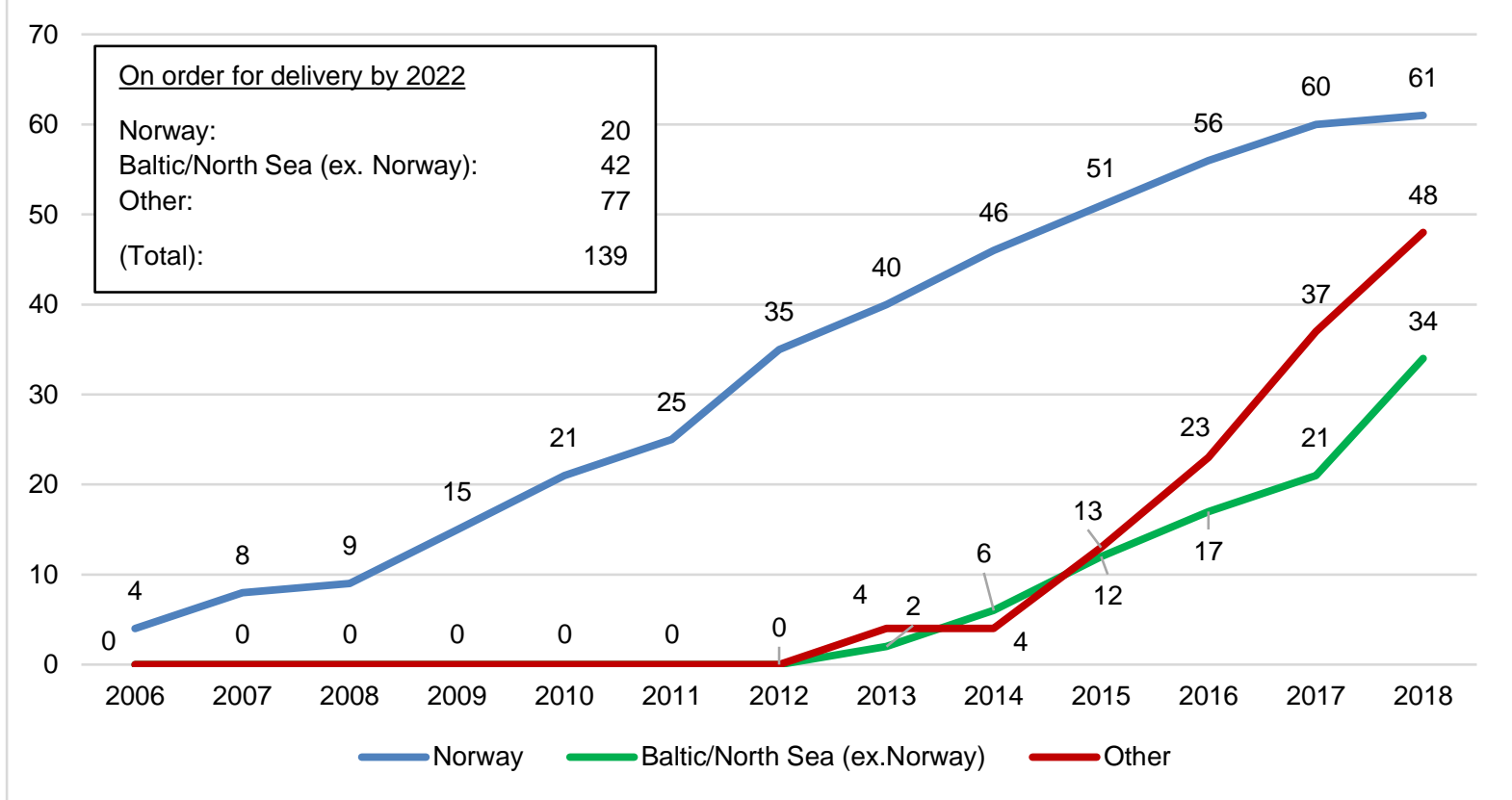

Source: Graph created by author. Data from DNV GL. 

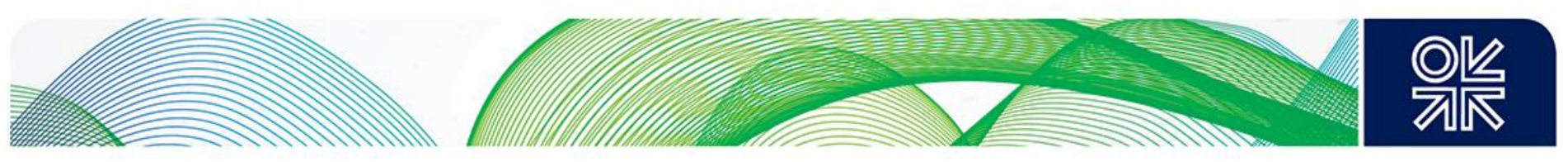

Figure 10: Global LNG-fuelled fleet in operation by vessel type and location (January 2019)

\begin{tabular}{|c|c|c|c|c|c|c|c|c|c|c|c|}
\hline \multicolumn{12}{|c|}{ LNG-fuelled vessels in operation by vessel class and location } \\
\hline & Norway & $\begin{array}{c}\text { Baltic/ } \\
\text { North } \\
\text { Sea }\end{array}$ & $\begin{array}{l}\text { Other } \\
\text { Europe }\end{array}$ & $\begin{array}{c}\text { North } \\
\text { America }\end{array}$ & $\begin{array}{l}\text { South } \\
\text { America }\end{array}$ & Asia & Oceania & $\begin{array}{c}\text { Middle } \\
\text { East }\end{array}$ & Global & Total & $\begin{array}{l}\text { BS/NS + } \\
\text { Norway }\end{array}$ \\
\hline Ferry & 24 & 8 & 2 & 8 & 1 & 0 & 0 & 0 & 0 & 43 & 32 \\
\hline Cruise & 0 & 0 & 0 & 0 & 0 & 0 & 0 & 0 & 1 & 1 & 0 \\
\hline PSV & 16 & 0 & 0 & 5 & 0 & 0 & 1 & 0 & 0 & 22 & 16 \\
\hline Tug & 5 & 0 & 0 & 0 & 0 & 7 & 0 & 0 & 0 & 12 & 5 \\
\hline Other Service & 3 & 6 & 0 & 0 & 0 & 1 & 0 & 0 & 0 & 10 & 9 \\
\hline Gas Carrier & 0 & 4 & 0 & 0 & 0 & 0 & 0 & 0 & 13 & 17 & 4 \\
\hline Bulk Carrier & 0 & 4 & 0 & 0 & 0 & 1 & 0 & 0 & 0 & 5 & 4 \\
\hline General Cargo & 5 & 0 & 0 & 0 & 0 & 0 & 0 & 0 & 0 & 5 & 5 \\
\hline Container & 0 & 2 & 0 & 4 & 0 & 0 & 0 & 0 & 0 & 6 & 2 \\
\hline Ro-Ro Cargo & 2 & 0 & 0 & 0 & 0 & 0 & 1 & 0 & 0 & 3 & 2 \\
\hline Car Carrier & 0 & 2 & 0 & 0 & 0 & 0 & 0 & 0 & 0 & 2 & 2 \\
\hline $\begin{array}{l}\text { Oil/Chemical } \\
\text { Tanker }\end{array}$ & 6 & 8 & 0 & 2 & 0 & 0 & 0 & 0 & 1 & 17 & 14 \\
\hline Total & 61 & 34 & 2 & 19 & 1 & 9 & 2 & 0 & 15 & 143 & 95 \\
\hline
\end{tabular}

Source: Alternative Fuels Insight Platform, DNV GL. ${ }^{93}$

Note: 'BS/NS' denotes 'Baltic Sea / North Sea'.

As of January 2019, the global LNG-fuelled fleet is largely concentrated in Norway and the rest of the North Sea/Baltic Sea region, with more limited growth in North America and Asia, as highlighted in Figures 9 and 10. When vessels operating in the North Sea/Baltic Sea ECAs (95), North American/US Caribbean ECAs (19), and Chinese (non-IMO) ECA (4) are included, 118 of 143 (83 per cent) of LNGfuelled vessels currently in existence operate in a $\mathrm{SO}_{x}$ or $\mathrm{NO}_{x}$ emissions control area - a ratio that highlights the importance of environmental regulations in stimulating uptake of LNG as a bunker fuel. Of the 15 vessels operating at a 'global' level, 13 are gas carriers (namely carriers of gases other than LNG), most of which deliver their cargoes (such as ethane) to or from the USA and Europe. Therefore, the use of LNG as a bunker fuel for long-distance, 'global' shipping is currently mostly limited to niche operations, and to vessels that begin and end their journeys in ECAs.

Regarding the character of the global LNG-fuelled fleet of 143 vessels, it is important to note that just eight (6 per cent) are retrofit projects, leaving the rest as newbuild vessels. Those retrofit vessels may be found in Norway (three), Northern Europe (three), the Mediterranean (one), and North America (one), with the Norwegian vessels relaunched between 2011 and 2015, and the non-Norwegian vessels launched between 2015 and 2018. This trend is the practical result of the economic pros and cons of LNG propulsion discussed earlier. Specifically, that LNG is most attractive to vessels operating almost continuously in a region with stringent emissions regulations (such as Norway from 2007 onwards regarding $\mathrm{NO}_{x}$ emissions and Northern Europe/North America from 2015 onwards regarding $\mathrm{SO}_{\mathrm{x}}$ emissions, together with passenger vessels in $\mathrm{EU}$ waters from 2014 onwards regarding $\mathrm{SO}_{\mathrm{x}}$ emissions). The vessels also require regular access to LNG bunkering infrastructure, which has developed substantially in Norway and Northern Europe since 2010. Finally, the higher the level of annual fuel consumption, the faster the capital investment is recouped, due to the discounted price of LNG relative to LSMGO (0.1 per cent sulphur) that must be consumed in the IMO ECAs. The eight retrofit vessels are of larger types (four ferries, three oil product/chemical tankers, and a container ship), which are likely to have higher fuel consumption than smaller vessels.

\footnotetext{
${ }^{93}$ Alternative Fuels Insight platform, DNV GL, 2019, op. cit.
} 

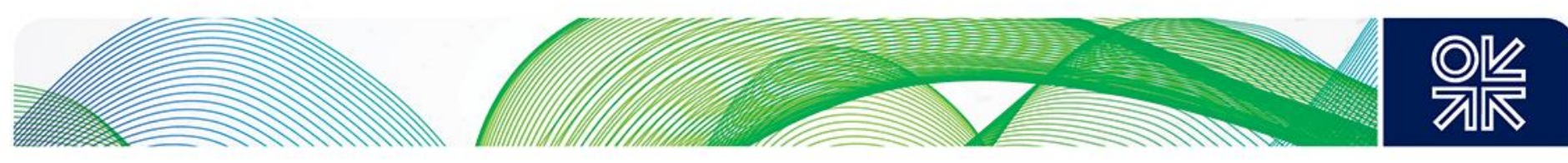

Of the 143 LNG-fuelled vessels in operation listed by DNV GL, 98 (69 per cent) are 'dual fuel', 29 (20 per cent) are 'pure LNG', and 15 (10 per cent) are 'pure gas + diesel', leaving just one with 'dual-fuel turbine' propulsion. Of the 139 vessels on order, 89 (64 per cent) are dual fuel and 14 (10 per cent) are pure gas, while the remaining 36 (26 per cent) are 'unknown'. ${ }^{94}$

Of the vessels running purely on LNG, 26 of 29 in operation and 12 of 14 on order are Norwegian. All 15 of the pure gas + diesel propelled vessels in operation are also Norwegian (none listed as being on order). Of the 82 non-Norwegian LNG-fuelled vessels currently in operation, 78 (95 per cent) are dual fuel. Of the 119 vessels on order outside Norway, 86 (72 per cent) are dual fuel, two (less than two per cent) are pure gas, and 31 (26 per cent) are 'unknown'. ${ }^{95}$ These statistics show that, outside Norway, dual-fuel engines are by far the most popular. This allows the possibility that these vessels may not be always running on LNG, and indeed may be doing so only in the ECAs.

The notable conclusions to be drawn here are:

- The $\mathrm{NO}_{x}$ tax and Fund in Norway (along with the ready supply of Norwegian-produced LNG) was sufficient to spur LNG-fuelled passenger/PSV shipping in Norway since 2007.

- In the North Sea/Baltic Sea ECAs and North American/US Caribbean ECAs, the growth of LNGfuelled shipping correlates with the reduction of the sulphur cap from 1.0 per cent to 0.1 per cent in January 2015, and the entry into force of the North American/US Caribbean Tier III NOx limits for newbuild vessels in 2016.

These examples demonstrate the significant influence of environmental regulations on the uptake of LNG for shipping - an experience that could be repeated when the global limits on $\mathrm{SO}_{\mathrm{x}}$ emissions enter into force in January 2020.

\section{Future growth of the LNG-fuelled fleet}

The future growth of the LNG-fuelled fleet may be estimated by the order book for newbuild vessels and for retrofit projects to convert existing vessels to LNG propulsion. In January 2019, DNV GL stated that 139 LNG-fuelled ships are on order for 2018-26. The range of vessel types, and their likely geographical areas of operation, are illustrated in Figure 12. Globally, there are a further 139 'LNG ready' vessels either currently in operation or on order. ${ }^{96,97}$

The LNG-fuelled fleet in Norway and the North Sea/Baltic Sea region has grown strongly, from three at the beginning of 2006 to 35 in 2012, and further to 95 by 2018. The current order book of 62 vessels suggests that the fleet size could reach 157 by 2022 . Meanwhile, the global LNG-fuelled fleet is set to double in size (from 143 to 282) by 2026, with all but nine of the current orderbook due for delivery by the end of 2022. With specific regard to the North Sea/Baltic Sea region (including Norway), Figure 11 illustrates the types of vessels currently in operation and the vessels on order that will join the fleet in the coming four years.

\footnotetext{
${ }^{94}$ See Appendix 3 for a brief explanation of different engine types for LNG-fuelled vessels

${ }^{95}$ Alternative Fuels Insight platform, DNV GL, 2019, op. cit.

${ }^{96}$ Alternative Fuels Insight platform, DNV GL, 2019, op. cit.

${ }^{97}$ LNG ready service. Oslo: DNV GL, 2018.

http://production.presstogo.com/fileroot6/gallery/dnvgl/files/original/5ba3027ea0b74cabacd71ad147a82d9b/5ba3027ea0b74cab acd71ad147a82d9b low.pdf. Sourced on 28 June 2018.
} 

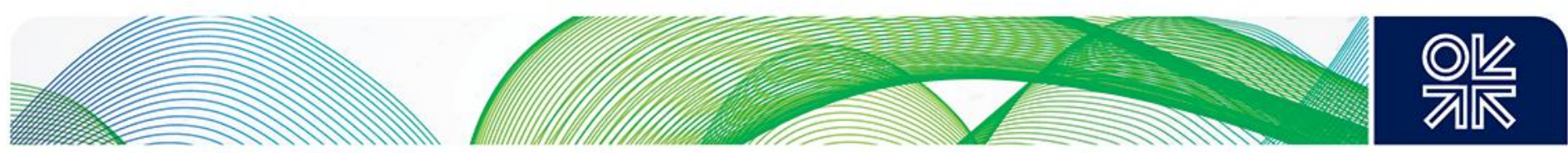

Figure 11: Vessels in operation and on order by type in the North Sea/Baltic Sea region, including Norway (January 2019)

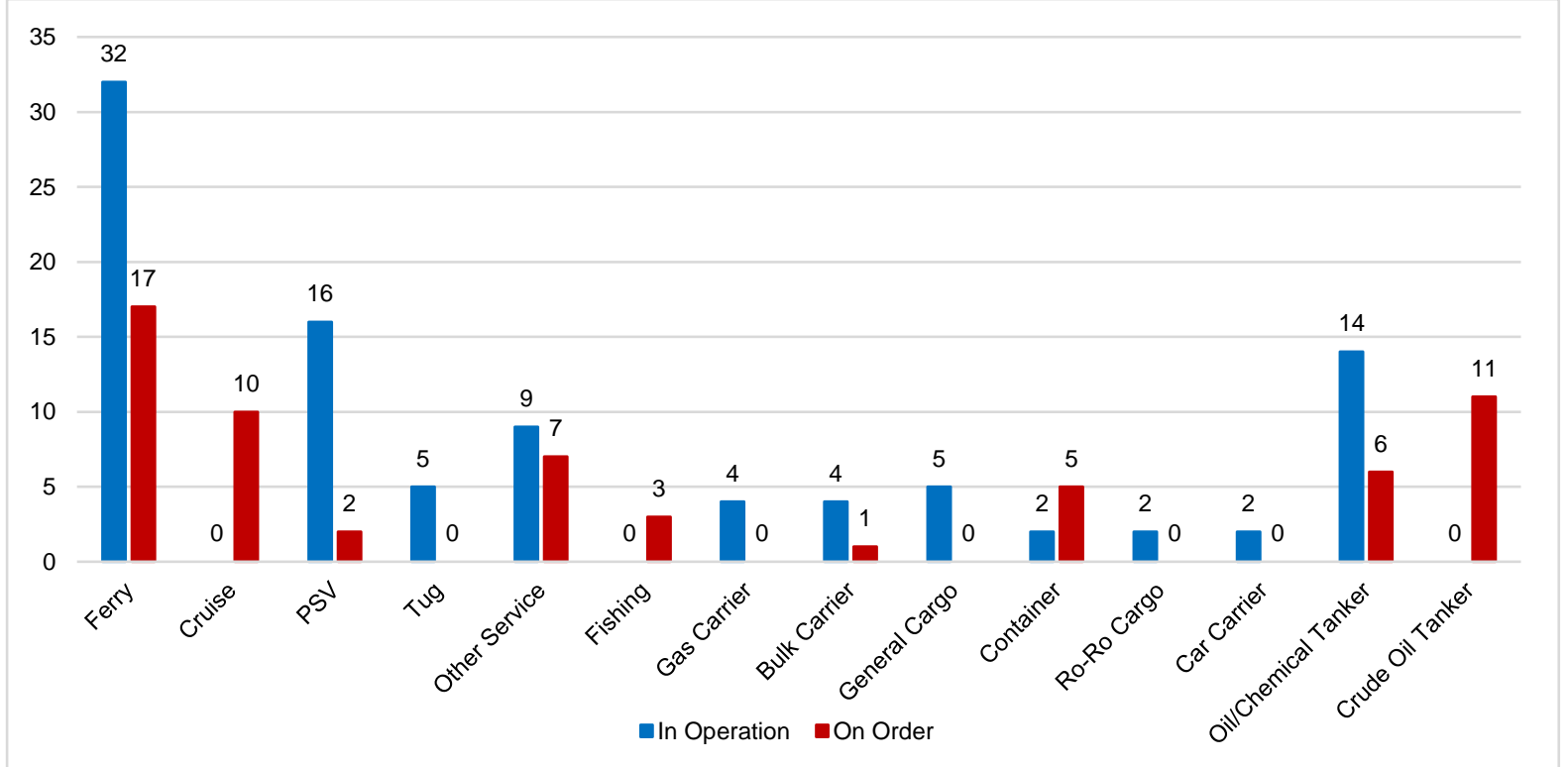

Source: Graph created by author. Data from DNV GL.

In particular, this graph illustrates the extent to which vessels that usually operate in a fixed geographical area (often continuously within the North Sea/Baltic Sea ECAs) have dominated the fleet. Of the 95 LNG-fuelled vessels currently in operation in Northern Europe, two-thirds (62 vessels) are ferries, PSV, tugs, and other service vessels. It is also worth noting that, of the $14 \mathrm{LNG}$-fuelled oil/chemical tankers currently operating in Northern Europe, 13 have been launched since 2015.

Looking forward, ferries and service vessels remain important, but it is the continued growth in the number of oil/chemical tankers and new growth in crude oil tankers, cruise ships, and container ships that stands out. These are large vessels that will have greater per-vessel annual fuel consumption than small vessels, such as PSVs, tugs, and service vessels. The expansion of the fleet of larger LNG-fuelled vessels will thus accelerate the demand for LNG as a bunker fuel.

The expected growth of LNG-fuelled vessels operating at a 'global' level (mostly cruise ships and large cargo vessels, including container ships and tankers carrying crude oil or refined products) reflects the advance impact of the January $2020 \mathrm{SO}_{x}$ emissions restrictions. This is important because, as noted above, these are larger, heavier vessels with higher levels of fuel consumption per vessel, and this will increase the rate at which total demand for $L N G$ as a bunker fuel will grow. Taken together, the growth in the regional (North Sea/Baltic Sea) and global LNG-fuelled fleet and the larger average vessel size, suggests a substantial growth in LNG bunker fuel demand at a regional and global level. If, in the early 2020s, a substantial number of the 'LNG ready' vessels are also converted to LNG propulsion, then demand for LNG bunker fuel could rise even further.

To put this growth into context, it is useful to consider the share of LNG-fuelled vessels in the total number of vessels on order. This illustrates the extent to which LNG is being 'phased into' the global fleet. According to Clarksons, the global orderbook-to-fleet ratio is around 10 per cent in tonnage (capacity) terms. ${ }^{98}$ In terms of vessel numbers, Seatrade Maritime News quotes a report from Crucial

\footnotetext{
98 'A closer look at a supply side "Rule of Thumb"...', Clarksons Research, 3 August 2018. https://clarksonsresearch.wordpress.com/2018/08/03/a-closer-look-at-a-supply-side-rule-of-thumb/. Sourced on 5 October 2018.
} 

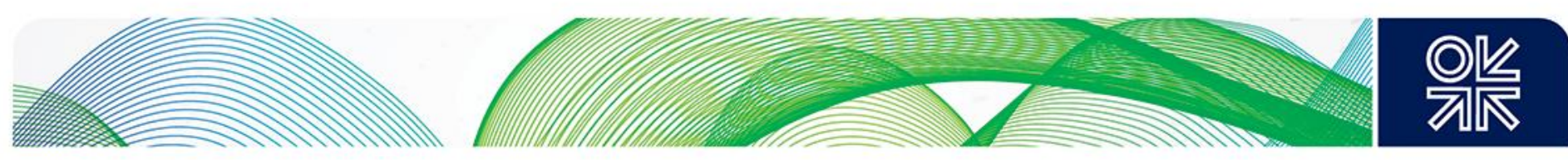

Perspectives, which states that there are 3,500 vessels currently on order - equal to 3.7 per cent of the current fleet of 95,000 marine vessels. ${ }^{99}$ With 139 LNG-fuelled vessels on order, the share of LNGfuelled vessels in the total number of vessels on order stands at 3.9 per cent. At that rate, the 'phasing in' of LNG will certainly be slow and steady, rather than rapid and spectacular.

Figure 12: Global LNG-fuelled fleet on order by vessel type and location

\begin{tabular}{|c|c|c|c|c|c|c|c|c|c|c|c|}
\hline \multicolumn{12}{|c|}{ LNG-fuelled vessels on order by vessel class and location } \\
\hline & Norway & $\begin{array}{l}\text { Baltic/ } \\
\text { North } \\
\text { Sea }\end{array}$ & $\begin{array}{l}\text { Other } \\
\text { Europe }\end{array}$ & $\begin{array}{c}\text { North } \\
\text { America }\end{array}$ & $\begin{array}{c}\text { South } \\
\text { America }\end{array}$ & Asia & Oceania & $\begin{array}{c}\text { Middle } \\
\text { East }\end{array}$ & Global & Total & $\begin{array}{l}\text { BS/NS + } \\
\text { Norway }\end{array}$ \\
\hline Ferry & 5 & 12 & 6 & 2 & 0 & 0 & 0 & 0 & 0 & 25 & 17 \\
\hline Cruise & 10 & 0 & 0 & 0 & 0 & 0 & 0 & 0 & 21 & 31 & 10 \\
\hline PSV & 2 & 0 & 0 & 1 & 0 & 0 & 0 & 0 & 0 & 3 & 2 \\
\hline Tug & 0 & 0 & 0 & 0 & 0 & 3 & 0 & 1 & 0 & 4 & 0 \\
\hline Other Service & 0 & 7 & 2 & 0 & 0 & 0 & 0 & 0 & 3 & 12 & 7 \\
\hline Fishing & 3 & 0 & 0 & 0 & 0 & 0 & 0 & 0 & 0 & 3 & 3 \\
\hline Gas Carrier & 0 & 0 & 0 & 0 & 0 & 0 & 0 & 0 & 0 & 0 & 0 \\
\hline Bulk Carrier & 0 & 1 & 0 & 0 & 0 & 0 & 0 & 0 & 2 & 3 & 1 \\
\hline General Cargo & 0 & 0 & 0 & 0 & 0 & 0 & 0 & 0 & 1 & 1 & 0 \\
\hline Container & 0 & 5 & 4 & 2 & 0 & 0 & 0 & 0 & 9 & 20 & 5 \\
\hline Ro-Ro Cargo & 0 & 0 & 0 & 2 & 0 & 0 & 0 & 0 & 0 & 2 & 0 \\
\hline Car Carrier & 0 & 0 & 0 & 0 & 0 & 0 & 0 & 0 & 2 & 2 & 0 \\
\hline $\begin{array}{l}\text { Crude Oil } \\
\text { Tanker }\end{array}$ & 0 & 11 & 0 & 0 & 0 & 0 & 0 & 0 & 10 & 21 & 11 \\
\hline $\begin{array}{l}\text { Oil/Chemical } \\
\text { Tanker }\end{array}$ & 0 & 6 & 0 & 1 & 0 & 3 & 0 & 0 & 2 & 12 & 6 \\
\hline Total & 20 & 42 & 12 & 8 & 0 & 6 & 0 & 1 & 50 & 139 & 62 \\
\hline
\end{tabular}

Source: Alternative Fuels Insight platform, DNV GL. ${ }^{100}$

The upside for LNG is that the growth in LNG propulsion is concentrated in larger vessels, with larger bunker fuel demands. For example, of the 110-121 cruise ships currently on order, 31 (26-28 per cent) are expected to be LNG-fuelled. ${ }^{101,102}$ Therefore, the share of LNG in total regional and global bunker fuel consumption may grow faster than the share of LNG-fuelled ships in the total number of vessels in the regional and global fleets. Furthermore, as noted earlier, LNG propulsion is currently almost entirely concentrated in $\mathrm{SO}_{x}$ Emissions Control Areas. As the impact of the January 2020 changes in IMO SOx emissions limits becomes clearer, it is possible that the rate of growth in LNG shipping may increase, as the owners of vessels operating outside the ECAs are forced to adapt to the new emissions limits.

\section{The regional non-LNG fuelled fleet and prospects for bunker fuel demand}

\section{The regional non-LNG fuelled fleet}

To put the statistics for the number of LNG-powered vessels operating in the North Sea and Baltic Sea region into context, it is necessary to consider the number of non-LNG powered vessels operating in

\footnotetext{
99 'Newbuild orderbook vs existing fleet capacity at 20 year low', Seatrade Maritime News, Hand. M., 21 February. http://www.seatrade-maritime.com/news/asia/newbuild-orderbook-vs-existing-fleet-capacity-at-20-year-low.html. Sourced on 14 November 2018.

100 Alternative Fuels Insight platform, DNV GL, 2019, op. cit.

101 'Seatrade Cruise Orderbook' [Updated 19 November 2018], Seatrade Cruise, 2018. http://www.seatradecruise.com/images/orderbook/Seatrade Cruise Orderbook.pdf. Sourced on 19 November 2018.

102 'Cruise Ship Orderbook', Cruise Industry News, 2018. https://www.cruiseindustrynews.com/cruise-news/cruise-shiporderbook.html. Sourced on 19 November 2018.
} 

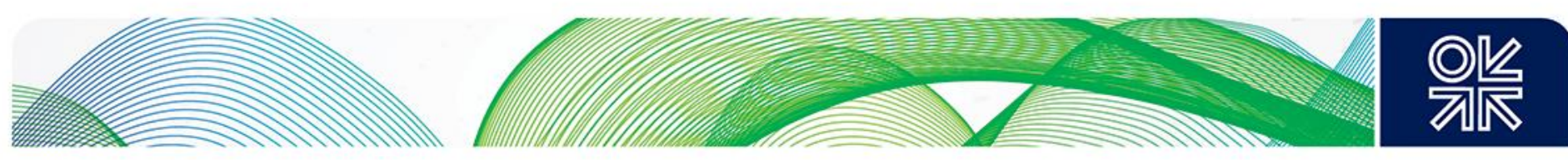

the same geographical area. To make this comparison, two data sets are used. The first is published by the UN Conference on Trade and Development (UNCTAD), and the second is from Marine Traffic.

The UNCTAD data set lists the number of vessels flagged for each country, by vessel type. ${ }^{103}$ (See Figure 13.) Here it is possible to identify vessels flagged to states with coastlines on the North Sea $E \mathrm{EA}^{104}$ and the Baltic Sea ECA. ${ }^{105}$ It is worth noting that this method is very much a rough estimate, which excludes non-locally flagged vessels visiting the North Sea and Baltic Sea ECA. This method also excludes Russian vessels operating in the Baltic Sea, because they cannot be separated from vessels operating from Russia's other ports and coastlines (such as the Black Sea and Far East).

The Marine Traffic vessel database also allows a 'flag-based' identification method. Vessels under $30 \mathrm{~m}$ in length are more likely to operate on inland waterways, and are thus excluded. There are slightly fewer than 60,000 such small $(<30 \mathrm{~m})$ vessels flagged to littoral states of the North Sea and Baltic Sea, and locally operational. This list is refined further, by filtering the vessels according to their area of operation, to include only those vessels operating in the North Sea and Baltic Sea ECAs. ${ }^{106,107}$ (See Figure 13.)

When the Marine Traffic data is examined in more detail, the extent to which LNG propulsion remains a niche sector becomes apparent. Of the 1,431 passenger vessels operating in the North Sea/Baltic Sea ECAs, just 32 (2.2 per cent) are LNG fuelled. Of the 4,003 cargo vessels and tankers operating in the same area, just 33 (0.8 per cent) are LNG-fuelled. Of the 2,655 tugs and special purpose vessels, just 30 (1.1 per cent) are LNG-fuelled. Overall, just under 1 per cent of the vessels operating in the North Sea/Baltic Sea ECAs are LNG fuelled.

Figure 13: Vessels by type operating in the North Sea and Baltic Sea (UNCTAD and Marine Traffic statistics)

\begin{tabular}{|l|r|r|r|r|r|r|}
\hline \multicolumn{7}{|c|}{ Number of vessels in the North Sea and Baltic Sea } \\
\hline & ONCTAD statistics (locally flagged) \\
\hline & Oil tankers & Bulk carriers & $\begin{array}{r}\text { General } \\
\text { cargo }\end{array}$ & $\begin{array}{r}\text { Container } \\
\text { ships }\end{array}$ & $\begin{array}{r}\text { Other types } \\
\text { of ships }\end{array}$ & Total fleet \\
\hline North Sea & 439 & 270 & 1,257 & 404 & 4,058 & 6,428 \\
\hline Baltic Sea & 49 & 8 & 221 & 5 & 686 & 969 \\
\hline Total & 488 & 278 & 1,478 & 409 & 4,744 & 7,397 \\
\hline & Marine Traffic Statistics (locally flagged and locally operational) & $\begin{array}{r}\text { Tugs \& } \\
\text { Tankers }\end{array}$ \\
\hline
\end{tabular}

Source: UNCTAD Stats ${ }^{108}$ and Vessels Database, Marine Traffic. ${ }^{109}$

\footnotetext{
${ }^{103}$ UNCTAD Stats - Data Centre - Merchant fleet by flag of registration and by type of ship, annual, 1980-2018 - Number of ships by category in 2018. http://unctadstat.unctad.org. Sourced on 29 June 2018.

${ }^{104}$ Belgium, Denmark, France, Germany, Netherlands, Norway, and the UK.

105 Estonia, Finland, Latvia, Lithuania, Poland, and Sweden.

106 'Areas of the world: How does Marine Traffic segment them?', Marine Traffic, 2018. https://help.marinetraffic.com/hc/enus/articles/214556408-Areas-of-the-World-How-does-MarineTraffic-segment-them-. Sourced on 2 July 2018.

107 Vessels database, Marine Traffic, 2018. https://www.marinetraffic.com. Sourced on 2 July 2018.

108 UNCTAD Stats - Data Centre - Merchant fleet by flag of registration and by type of ship, annual, 1980-2018 - Number of ships by category in 2018 , op. cit.

109 Vessels database, Marine Traffic, 2018, op. cit.
} 

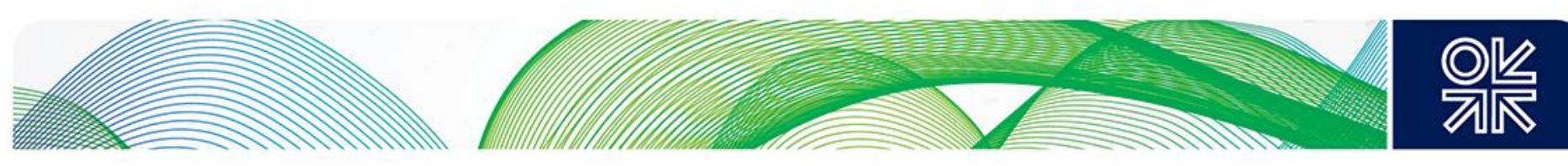

On the one hand, these figures demonstrate the extent to which LNG propulsion remains a minority choice for vessel owners. On the other, they show the potential for growth in alternative fuels and the scale of adaptation necessary from January 2020. DNV GL states that - at a global level - 3,247 vessels currently in operation or on order are utilising some form of adaptation to new environmental regulations: 2,702 vessels with scrubbers; 282 vessels with LNG propulsion (plus another 139 as 'LNG ready'), 12 fuelled by methanol, six fuelled by LPG, and 300 battery propelled. Of the latter, 164 are hybrid (such as LNG-battery and LSMGO-battery), 75 are plug-in hybrid, 47 are pure electric, and 14 are 'unknown'.

The 1,031 vessels in operation (globally) in 2018 that are using some form of adaptation include 769 with scrubbers ( 75 per cent), 143 fuelled by LNG (14 per cent), and 119 battery powered (including hybrids) (11 per cent). ${ }^{110}$ This equates to just 0.4 per cent of the 248,992 passenger, cargo, and tanker vessels of at least $30 \mathrm{~m}$ in length currently in operation worldwide, as identified by Marine Traffic.

The uptake of scrubbers is mostly by large cargo vessels. Of the 2,702 vessels in operation or on order with scrubbers, 2,257 (84 per cent) are bulk carriers, car carriers, container ships, crude oil tankers, gas tankers, general cargo ships, oil product/chemical tankers, and ro-ro cargo ships, while a further 258 (10 per cent) are cruise ships. Just 84 vessels (in operation or on order), belonging to the categories of ferries, fishing vessels, offshore supply ships, and 'other service vessels', have opted for scrubbers.

By contrast, the uptake of battery propulsion is largely focused on vessels that operate over relatively short distances, in relatively limited geographical areas - precisely those vessel types that have not opted for scrubbers. Of the 300 battery-powered vessels in operation and on order, passenger ferries, roll-on, roll-off passenger ferries (ropax), and other passenger vessels account for 136 (45 per cent), while fishing vessels, tugs, offshore supply ships, other offshore vessels, and vessels engaged in 'other activities' (such as dredgers), account for a further 124 (41 per cent). By contrast, bulk carriers, container ships, crude oil tankers, general cargo ships, oil product/chemical tankers, and ro-ro cargo ships account for just 22 (7 per cent), with cruise ships also accounting for 17 (6 per cent).

Even if all of the 1,031 vessels currently using some form of abatement were operational in the North Sea/Baltic Sea, this would only account for around one in ten vessels currently operating in that geographical area. The reality is that those vessels are likely spread between the North Sea/Baltic Sea and the North American/US Caribbean ECAs, and other locations around the world (including the Chinese non-IMO SO$x$ emissions control areas). This means that most vessels in the North Sea/Baltic Sea ECAs are not using a specific abatement system, and are therefore likely to be fuelled by lowsulphur marine gasoil - a trend borne out by an examination of bunker fuel sales in the region.

\section{Challenges in measuring current regional bunker fuel demand}

The first challenge in measuring current bunker fuel demand in the North Sea/Baltic Sea region is finding consistent data. There are two approaches to gathering such data. The first is calculating fuel consumption per vessel, and the second is measuring bunker sales in ports. The first approach is taken by the International Council on Clean Transportation (ICCT), and the second by the IEA and Eurostat. (For example: while the ICCT reports bunker fuel consumption by all Dutch-flagged vessels, the IEA and Eurostat report bunker fuel provided by Dutch ports to all vessels, regardless of their flag states.)

In its most recent statistics, the ICCT lists 63,198 vessels flagged to littoral states of the North Sea and Baltic Sea ECAs in 2015. This clearly includes the small, inland waterway vessels that were identified by Marine Traffic but excluded from the analysis (and Figure 13) above.

According to the ICCT database, in 2015, those North Sea/Baltic Sea-flagged ships consumed 8.0 million tonnes of residual fuel oil, 8.9 million tonnes of distillate fuel (marine gasoil (MGO) or marine diesel oil (MDO)), and 0.36 million tonnes of LNG as bunker fuel. These figures are converted to million

${ }^{110}$ Alternative Fuels Insight platform, DNV GL, 2019, op. cit. 

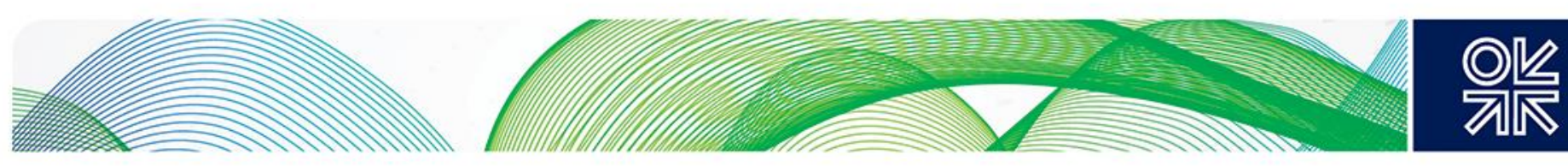

tonnes of LNG equivalent (mt LNG-eq) using the conversion factors provided by Le Fevre, ${ }^{111}$ and given in Figure 14.

The ICCT also provides data for an additional 1,789 vessels from the International Registers of Shipping (Int. Reg.) for Norway, Denmark, and France, and for Isle of Man-flagged vessels from the UK. These vessels are not subject to the same regulatory standards as vessels formally flagged to Norway, Denmark, France, and the UK, and are therefore reported separately. When data for these vessels are included, total North Sea/Baltic Sea consumption of fuel oil $(16.8 \mathrm{mt})$ and distillate fuel $(11.2 \mathrm{mt})$ gives $28.0 \mathrm{mt}$ of oil-based bunker fuel consumption, plus 759,539 tonnes of LNG bunker fuel consumption. These figures are also converted to tonnes of LNG-equivalent and presented in Figure 14.

\section{Figure 14: Regional bunker fuel consumption in 2015}

\begin{tabular}{|l|r|r|r|r|}
\hline \multicolumn{5}{|c|}{$\begin{array}{c}\text { Bunker fuel consumption by vessels flagged to North Sea/Baltic Sea littoral states in } 2015 \\
\text { (million tonnes of LNG equivalent and percentage of total) }\end{array}$} \\
\hline & Residual fuel oil & Distillate fuel & LNG & Total \\
\hline North Sea & $6.017 \mathrm{mt}(50.4 \%)$ & $5.595 \mathrm{mt}(46.9 \%)$ & $0.326 \mathrm{mt}(2.7 \%)$ & $11.938 \mathrm{mt}(100 \%)$ \\
\hline Baltic Sea & $0.252 \mathrm{mt}(12.0 \%)$ & $1.807 \mathrm{mt}(86.4 \%)$ & $0.034 \mathrm{mt}(1.6 \%)$ & $2.093 \mathrm{mt} \mathrm{(100 \% )}$ \\
\hline Sub-Total & $6.269 \mathrm{mt}(44.7 \%)$ & $7.402 \mathrm{mt}(52.7 \%)$ & $0.360 \mathrm{mt}(2.6 \%)$ & $14.031 \mathrm{mt}(100 \%)$ \\
\hline Int. Reg. & $6.894 \mathrm{mt}(74.9 \%)$ & $1.911 \mathrm{mt}(20.8 \%)$ & $0.400 \mathrm{mt}(4.3 \%)$ & $9.205 \mathrm{mt}(100 \%)$ \\
\hline Total & $13.163 \mathrm{mt}(56.6 \%)$ & $9.313 \mathrm{mt}(40.1 \%)$ & $0.760 \mathrm{mt}(3.3 \%)$ & $23.236(100 \%)$ \\
\hline
\end{tabular}

Source: Greenhouse gas emissions from global shipping, ICCT. ${ }^{112}$

The 'International Register' vessels have an average fuel consumption of 5,145 tonnes of LNGeq, compared to average fuel consumption of 388 tonnes of LNGeq for the other 63,198 vessels flagged to littoral states of the North Sea and Baltic Sea ECAs. This suggests that the 'International Register' vessels are larger, and are likely to travel longer distances outside the North Sea and Baltic Sea ECAs. Conversely, many of the vessels flagged to the littoral states of the North Sea and Baltic Sea are likely to be smaller, possibly inland waterway, vessels.

Finally, the ICCT reports total global bunker fuel consumption of $212.9 \mathrm{mt}$ of fuel oil, $63.3 \mathrm{mt}$ of distillates, and $6.5 \mathrm{mt}$ of LNG, in 2015. The ICCT data is based on the IHS vessel database (not publicly available), which notes the fuel types for each vessel. Fuel types are identified for 99,434 vessels. However, the report states that fuel types for 56 per cent of the vessels in the database (predominantly smaller vessels) were missing, and were assumed on the basis of vessel size and engine speed. Fuel consumption was calculated using AIS satellite tracking data for each vessel. The IHS database identified 228 LNG-fuelled vessels in 2015 - a number substantially higher than the fleet size reported by DNV GL and LNG World Shipping. ${ }^{113}$ This discrepancy likely results from the IHS database including LNG-fuelled LNG carriers, while the DNV GL and LNG World Shipping databases exclude such vessels.

For comparison, the IEA states that, at a global level, fuel consumption for international marine bunkers in 2016 was 212.15 million tonnes (mt) of oil products and 50,000 tonnes of oil equivalent (toe) of LNG. The entire 50,000 toe of LNG bunker fuel consumption was reported as taking place in Norway, where oil-based bunker fuel consumption was also 0.05 mtoe. In the 13 countries of the North Sea/Baltic Sea

\footnotetext{
1111 tonne of fuel oil contains 40.7 MMBtu; 1 tonne of marine gasoil contains 43.3 MMBtu; 1 tonne of LNG contains 52.0 MMBtu. See 'A review of demand prospects for LNG as a marine transport fuel', Le Fevre, op.cit., page 8.

112 Greenhouse gas emissions from global shipping, 2013-2015 [Supplementary materials], ICCT (International Council on Clean Transportation), 2017. https://www.theicct.org/publications/GHG-emissions-global-shipping-2013-2015. Sourced on 12 September 2018.

${ }^{113}$ Greenhouse gas emissions from global shipping, 2013-2015 [Detailed methodology], ICCT, 2017. https://www.theicct.org/publications/GHG-emissions-global-shipping-2013-2015. Sourced on 12 September 2018.
} 

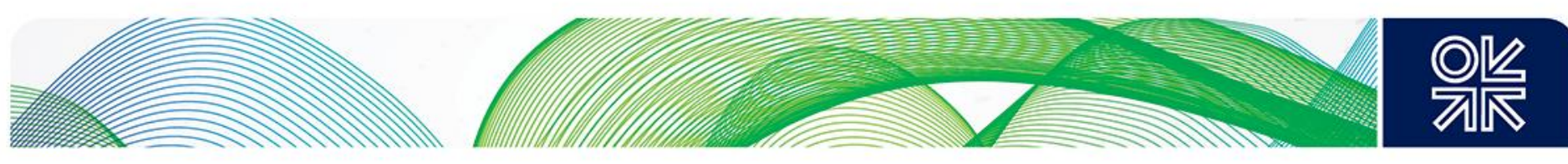

region, the consumption of oil-based fuels for international marine bunkering is recorded as $29.67 \mathrm{mtoe}$, while the provisional figure for 2017 is 28.88 mtoe. Provisional figures for consumption of LNG as a bunker fuel in 2017 are not given. ${ }^{114,115}$

The data for oil-based bunker fuel demand in 2015/16 from the ICCT and IEA are similar: oil-based bunker fuel consumption of around $212 \mathrm{mt}$ globally, and 28-29 mt in the North Sea/Baltic Sea region, in 2015/16. However, vessels flagged to states in the North Sea/Baltic Sea (especially those on the 'International Registers') may spend much of their time outside the region, while vessels flagged to other states are frequent visitors to the region, and take on bunker fuel when they visit the region.

With specific regard to LNG bunkering, ICCT reports demand in the North Sea/Baltic Sea region as 360,000 tonnes in 2015 (rising to 760,000 tonnes when 'International Register' ships from Norway, Denmark, France, and the UK are included). By contrast, the IEA reports North Sea/Baltic Sea regional LNG bunkering of just 50,000 toe (around 39,000 tonnes of LNG) in 2016. For comparison, Eurostat report consumption of LNG for international marine bunkering in Norway in 2016 (the most recent data) as 47,200 tonnes of oil equivalent (toe), up from 34,600 toe in 2015 and 800 toe in 2014. The figure reported by Eurostat for 2016 is therefore similar to that reported by the IEA. Total EU consumption of LNG in international marine bunkers is recorded as zero in 2015 and 1,100 toe in 2016 - the entire EU demand for LNG bunkering in 2016 is attributed to the Netherlands. ${ }^{116}$

Given that bunkering operations are not always reported, the 'vessel-based' approach of the ICCT is more likely to be accurate than the 'port-based' approach of the IEA and Eurostat. One example is the bunkering of the Finnish-flagged Viking Grace LNG-fuelled ferry in Stockholm. In December 2017, AGA announced that it had conducted over 1,400 bunkering operations of around 60 tonnes of LNG per operation since the spring of 2013. This equates to 17,685 tonnes per year for the bunkering of one vessel in Sweden alone. ${ }^{117}$ Eurostat and the IEA report no LNG bunkering in Sweden in 2016, while the ICCT report that Finnish-flagged vessels bunkered 24,086 tonnes of LNG in 2015.

A second challenge stems from the recent rapid rate of growth in LNG bunkering, given that the most recent ICCT data refers to 2015, and the most recent IEA/Eurostat data refers to 2016. Based on the growth of the LNG-fuelled fleet since 2015, and the launch of LNG bunkering in 2017 at LNG terminals in Zeebrugge, Klaipeda, and Lysekil and at the ports of Tallinn and Gothenburg, following the launch of LNG bunkering at the Pori LNG terminal and at the German ports of Rostock and Hamburg in 2016, the total regional LNG bunker fuel demand for the full year 2017 is likely to be substantially higher than 2015-16, and even higher in 2018.

An illustrative example is the Port of Rotterdam, where sales of LNG as a bunker fuel rose from 100 tonnes in 2016 to 1,500 tonnes in 2017, and reached 2,026 tonnes in H1 2018. ${ }^{118}$ Similarly, Eesti Gaas reports that, between February 2017 and June 2018, the Tallink Megastar LNG-fuelled ferry received 18,500 tonnes of LNG as bunker fuel over the course of 1,000 bunkering operations. ${ }^{119}$ The

\footnotetext{
${ }^{114}$ North Sea: Norway, the UK, France, Belgium, Netherlands, Germany, and Denmark; Baltic Sea: Poland, Sweden, Finland, Estonia, Latvia, and Lithuania.

${ }^{15}$ World Energy Balances 2018, IEA, 2018. https://www.oecd-ilibrary.org/energy/world-energy-balances2018 world energy bal-2018-en. Sourced on 13 September 2018. (See pages II.5; II.34.)

Supply, transformation and consumption of gas - annual data [nrg_103a], Eurostat, 2018.

https://ec.europa.eu/eurostat/data/database. Sourced on 12 September 2018. (See sub-section 'International Marine Bunkers' B_100800)

'AGA renews LNG contract with Viking Line', Press release, AGA, 21 December 2017. http://www.aga.se/en/news ren/news1/news20171221a.html. Sourced on 13 September 2018.

'Bunker sales in the port of Rotterdam', Port of Rotterdam, 2018. https://www.portofrotterdam.com/sites/default/files/bunkersales-port-of-rotterdam.pdf?token=IGBi7vqS. Sourced on 12 September 2018.

19 'LNG bunkering took place for the thousandth time in Tallinn old city harbour at midnight', Press release, Eesti Gaas, 12 June 2018. https://www.gaas.ee/en/Ing-bunkering-took-place-for-the-thousandth-time-in-tallinn-old-city-harbor-at-midnight/. Sourced on 12 September 2018.
} 

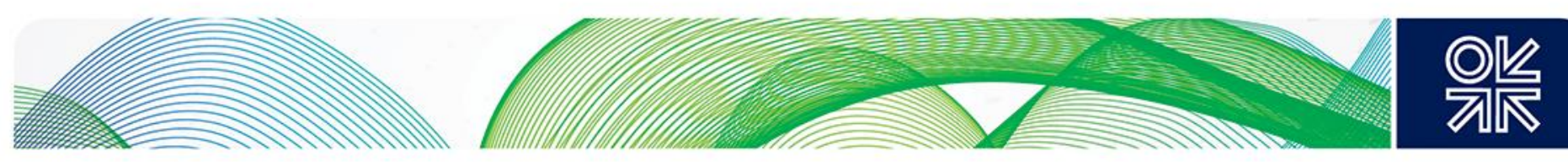

bunker fuel provided to the Tallink Megastar over that period equates to almost half the total volume of LNG bunker fuel consumption reported by the IEA and Eurostat for the whole of Norway in 2015, and represents a significant addition to regional LNG bunker fuel demand.

With the Viking Grace and Tallink Megastar each consuming around 15,000-18,000 tonnes of LNG per year, a conservative estimate of 14,000 tonnes of LNG per year consumed by each of the 65 large cargo and passenger vessels operating in the North Sea/Baltic Sea region, plus 3,000 tonnes per year consumed by each of the 30 smaller vessels (PSVs, tugs, and service vessels) operational in the region, gives a conservative figure of 1 million tonnes of LNG, equal to 1.36 billion cubic metres of natural gas.

While the ICCT estimate LNG bunker fuel consumption by vessels flagged to littoral states of the North Sea/Baltic Sea in 2015 as 760,000 tonnes, the actual figure for the latest full year (2018) is likely to be higher, because the ICCT figure does not include non-locally-flagged vessels taking on bunker fuel in the region, and because the LNG-fuelled fleet and bunkering network are growing so quickly.

\section{Future regional bunker fuel demand}

The current rate of growth in regional LNG bunker fuel demand will be maintained by the launch of new LNG-fuelled vessels in the coming years. As discussed earlier, the North Sea/Baltic Sea regional fleet, and the global fleet, are set to grow by 65 and 91 per cent respectively, in the coming four years. However, demand for LNG as a bunker fuel is likely to grow even more quickly, given the growing average size of LNG-fuelled vessels (thanks to the launch of LNG-fuelled cruise ships, container ships, and oil tankers). More vessels will be added to the order book in the next few years, in addition to the 'LNG ready' vessels that may switch to LNG propulsion when the new IMO sulphur restrictions come into effect in January 2020.

Therefore, with current North Sea/Baltic Sea regional demand for LNG bunker fuel estimated at $1.0 \mathrm{mt}$ of $L N G(1.36 \mathrm{bcm})$, it is possible to estimate current demand outside the region as 518,000 tonnes of LNG $(0.7 \mathrm{bcm})$, based on the current non-European fleet of 34 large vessels and 14 smaller vessels and the annual per-vessel consumption estimates given above. Roughly speaking, this gives a current global demand of around $1.5 \mathrm{mt}$ of $L N G$ (or $2 \mathrm{bcm}$ of natural gas).

The notion that global demand for LNG bunker fuel could more than double by the end of 2022 would equate to total demand of 3-3.5 mt of LNG (4-5 bcm of natural gas). With LNG propulsion being 'phased in' through newbuilds rather than retrofits, that rate of growth could continue through the 2020s, as the global fleet ages and is replaced, vessel-by-vessel. Indeed, as the global bunkering network develops and spreads, the rate of growth may even increase. It is this vision of the future that drives the IEA forecasts for global LNG bunker fuel demand, as illustrated in Figure 15.

Figure 15: IEA forecasts for LNG bunker fuel demand

\begin{tabular}{|l|r|r|r|r|r|}
\hline \multicolumn{6}{|c|}{ Global demand for LNG as bunker fuel by scenario (bcm per year) } \\
\hline & 2016 & 2025 & 2030 & 2035 & 2040 \\
\hline Current Policies & 0 & 10 & 17 & - & 38 \\
\hline New Policies & 0 & 16 & 26 & 37 & 51 \\
\hline Sustainable Development & 0 & 33 & 41 & 50 & 57 \\
\hline
\end{tabular}

Source: World Energy Outlook 2017, IEA. ${ }^{120}$

${ }^{120}$ World Energy Outlook 2017, IEA, 2017. https://www.iea.org/weo/. Sourced on 13 September 2018. (See pages 339, 452, and 647). 

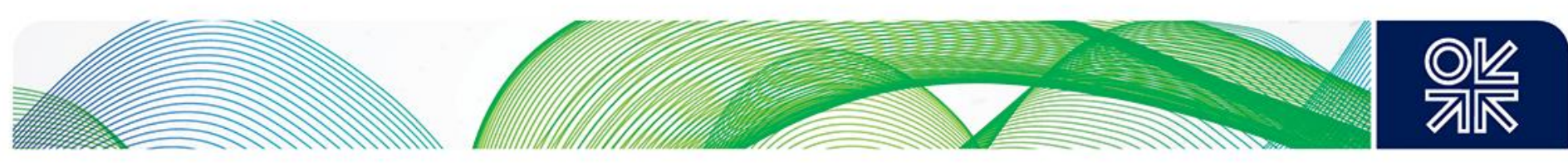

To gain a clearer idea of how market participants may react to those changes from January 2020 onwards, and the extent to which those market participants view LNG as a commercially viable path to regulatory compliance, it is useful to consider the experiences of market participants in the North Sea/Baltic Sea ECAs, and the extent to which their actions have been driven by both commercial opportunities and the need for compliance with environmental regulations.

\section{Significant actors in the North Sea/Baltic Sea LNG supply chain}

\section{Gasnor (majority owned by Shell since 2012)}

\section{Overview and company history}

Gasnor was the 'first mover' in terms of small-scale Norwegian LNG, as the owner-operator of the Snurrevarden and Kollsnes I small-scale LNG export terminals from 2003, and the Kollsnes II smallscale LNG export terminal and Mosjøen small-scale LNG import terminal from 2007. In addition to the distribution of LNG via its fleet of tanker trucks, Gasnor began distributing LNG with its small-scale LNG carrier, the Pioneer Knutsen, from 2004. This was complemented by the charter of the Coral Methane, a small-scale LNG carrier owned by Anthony Veder, from 2009. The construction of the Coral Methane was partially subsidised by the Norwegian $\mathrm{NO}_{x}$ Fund. According to Gasnor:

\footnotetext{
The company started up supplying natural gas to Norwegian industry in 1994 through a pipeline network similar to the European model... Gasnor was early to recognize that if major parts of the Norwegian industry should be able to convert to a cleaner and more environmentally friendly fuel, it would not be practical to distribute gas through a pipeline network. Liquefied natural gas (LNG) is a more appropriate form of distribution over longer distances with difficult topography... LNG not only provides greater flexibility in terms of distribution, it also allows for gas to be used as fuel in ships and heavy-duty trucks and buses... We currently deliver natural gas to large parts of Norwegian industry, as well as a growing fleet of natural gas-powered ships.
}

Gasnor has been a wholly owned subsidiary of Shell since September 2012. Prior to this, the largest shareholder was Statoil (41 per cent), along with the Norwegian power company BKK (20 per cent), E.ON (14 per cent), the Norwegian power company Haugaland Kraft (13.4 per cent), Total (7.4 per cent), and Shell (4.1 per cent). ${ }^{121}$

\section{Analysis}

The history of Gasnor and its assets highlights the fact that the company's focus was initially on the domestic Norwegian market, and specifically on the supply of LNG to industry and both land-based and marine transport. This domestic focus was also reflected in the fact that, until 2012, Gasnor was majority owned (74.4 per cent) by three Norwegian companies. In addition to the supply of LNG to industrial consumers by its fleet of trucks, Gasnor's supply of LNG to the marine shipping market in Norway was surely influenced by the Norwegian government subsidies for LNG propulsion and the related uptake of $L N G$ as a shipping fuel in Norway, which proceeded at a faster pace than in its regional neighbours.

From 2009 onwards, the charter of the Coral Methane enabled Gasnor to participate more actively in the regional small-scale LNG market. Specifically, the Coral Methane conducted the world's first loading of a small-scale LNG carrier at a large-scale LNG terminal, at Zeebrugge in May 2010. That cargo was delivered back to Norway for ship-to-ship transfer to the Pioneer Knutsen and distribution via Gasnor's

\footnotetext{
${ }^{121}$ Annual report 2011, Gasnor, 2012. https://gasnor.no/wp-content/uploads/2012/11/Annual-Report-20111.pdf. Sourced on 22 August 2018. See page 28.
} 

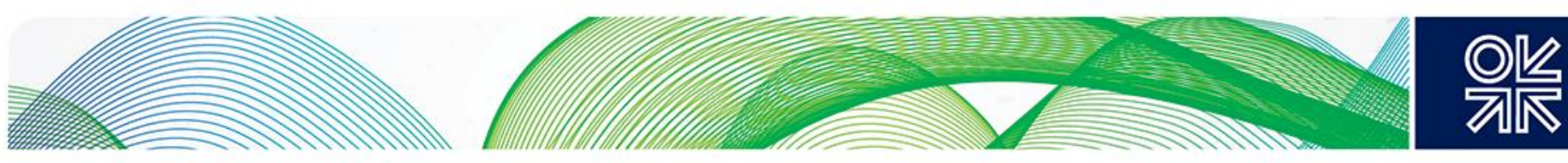

Norwegian terminals. ${ }^{122}$ The Coral Methane also received the first small-scale LNG reload at the Gate LNG terminal in Rotterdam, in 2013; the cargo was subsequently delivered to the AGA-owned LNG terminal at Nynäshamn (Sweden). ${ }^{123,124}$

Gasnor's parent company, Shell, has also begun to participate in the regional small-scale LNG and LNG bunkering market. Specifically, as mentioned earlier, Shell owns the LNG bunker vessel, Cardissa, which has been based at the Gate LNG terminal in Rotterdam since its launch in 2017. When its modification is complete, the Coral Methane will be Shell's second LNG bunker vessel. Shell's interest in LNG bunker vessels is undoubtedly linked to the contracts it signed, in April and November 2017, to supply LNG as a bunker fuel to Sovcomflot's new LNG-fuelled Aframax oil tankers and to Carnival Corp's LNG-fuelled cruise liners, from 2018 and 2020 respectively. ${ }^{125,126}$ Then, in February 2018, Shell chartered two more of Sovcomflot's ice-class LNG-fuelled oil tankers for its own oil transportation needs in Northern Europe - Shell itself will provide the LNG bunker fuel for those vessels. ${ }^{127}$

While Gasnor remains predominantly focused on the Norwegian market, it is possible to conclude that it was the combination of Gasnor's prior experience and the tightening of regional $\mathrm{SO}_{\mathrm{x}}$ emissions restrictions in 2015 that motivated Shell to engage in the LNG bunkering market directly. Not only has growing regional demand for LNG as a bunker fuel opened a commercial opportunity for Shell to trade in that fuel, but Shell has also been forced to consider how it will carry out its own oil transportation activities under increasingly stringent environmental restrictions.

\section{Skangas (Gasum subsidiary)}

\section{Overview and company history}

Like Gasnor, Skangas is a Norwegian company that developed the capacity to produce LNG and deliver it to consumers. However, Gasnor has remained relatively focused on the domestic Norwegian market. By contrast, Skangas has created a regional value chain, from ownership of liquefaction plants in Norway through LNG carriers to small-scale LNG regasification terminals and bunkering facilities elsewhere in the North Sea/Baltic Sea region. According to the company website:

Skangas operates a complete value chain in liquefied natural gas (LNG) to serve the Nordic markets: Skangas offers LNG for use as fuel in shipping and heavy-duty road transport, and in industrial processes outside the gas network. Skangas operates an LNG portfolio that consists of the purchase

\footnotetext{
122 'First time LNG re-export into small LNG carrier "Coral Methane" from Fluxys Zeebrugge Terminal', TGE Marine, 25 May 2010. http://www.tge-marine.com/110-0-First-time-LNG-re-export-into-small-LNG-carrier-CORAL-METHANE-from-FluxysZeebrugge-Terminal.html. Sourced on 22 August 2018.

${ }_{123}$ 'Eneco reloads first small scale LNG vessel at Gate terminal', Press release, Gate Terminal, 11 September 2013. http://gate.nl/en/media/news/newsdetail/eneco-reloads-first-small-scale-Ing-vessel-at-gate-terminal.html. Sourced on 22 August 2018.

124 'AGA and Eneco enable first small scale LNG reload at the Gate terminal Rotterdam', Press release, Eneco, 10 July 2013. https://news.enecogroup.com/aga-and-eneco-enable-first-small-scale-Ing-reload-at-the-gate-terminal-rotterdam/. Sourced on 22 August 2018.

125 'Shell to fuel world's first LNG-powered crude oil tankers', Press release, Shell, 3 April 2017. https://www.shell.com/energyand-innovation/natural-gas/lng-for-transport/news-and-media-releases/shell-to-fuel-worlds-first-Ing-powered-crude-oiltanker.html and 'SCF Group partners with Shell to make the first global step towards LNG-fuelled oil tanker industry', Press release, SCF, 3 April 2017. www.scf-group.ru/en/press office/press releases/item86521.html. Sourced on 23 August 2018. 126 'Cruising into a cleaner future', Shell, 2017. https://www.shell.com/inside-energy/cruising-into-a-cleaner-future.html. Also: 'Carnival Cruise Line Signs Agreement with Shell to Fuel North America's First LNG-Powered Cruise Ships', Press release, Carnival Corp, 8 November 2017. https://carnival-news.com/2017/11/08/carnival-cruise-line-signs-agreement-with-shell-to-fuelnorth-americas-first-Ing-powered-cruise-ships/. Sourced on 23 August 2018.

27 'Shell charters two LNG-powered Aframaxes from Russia's Sovcomflot', LNG World News, 21 February 2018. https://www.Ingworldnews.com/shell-charters-two-Ing-powered-aframaxes-from-russias-sovcomflot/. Sourced on 23 August 2018.
} 

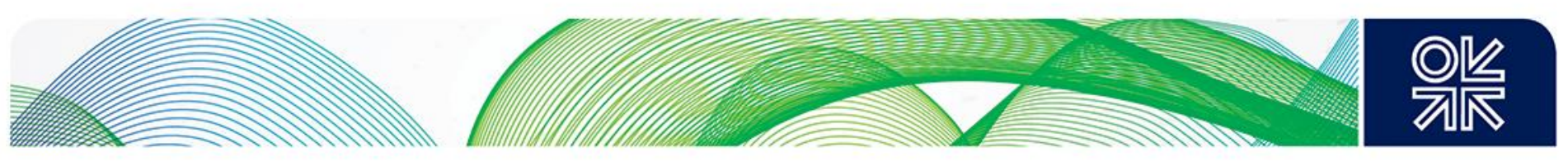

of feed gas, LNG liquefaction, distribution of LNG by trucks and ships through receiving terminals, to customer facilities where LNG is re-gasified to natural gas or delivered as fuel to the end-user. ${ }^{128}$

Skangas was founded in 2007 as a subsidiary of the Norwegian regional energy company, Lyse, to operate the Lyse-owned LNG production/export facility that was planned for construction at Risavika. ${ }^{129,130}$ Skangas was originally a 50/50 JV between Lyse and the financial investor, Celsius Invest. ${ }^{131}$

Also in 2007, Lyse agreed with the Norwegian shipping company, I.M. Skaugen, to form the joint venture 'Nordic LNG'. According to a July 2007 press release from I.M. Skaugen, Nordic LNG was owned 60 per cent by Lyse and 40 per cent by I.M. Skaugen: Lyse would contribute the supply of gas from the Risavika terminal, while I.M. Skaugen would contribute one new small-scale LNG carrier to deliver that gas to the Nordic market. ${ }^{132}$ That small-scale multigas carrier was the Norgas Innovation. ${ }^{133}$

In March 2010, Lyse raised its shareholding in Skangas from 50 per cent to 67.1 per cent. Then, in May 2010, Lyse acquired the remaining 40 per cent of Nordic LNG from I.M. Skaugen. ${ }^{134}$ Finally, in June 2011, Lyse bought out Celsius Invest's 32.9 per cent stake in Skangas. ${ }^{135}$ This gave Lyse total ownership over a supply chain from the Risavika LNG export terminal to the LNG sales and shipping business that had initially been developed in partnership with I.M. Skaugen.

The Finnish state-owned Gasum acquired a 51 per cent stake in Skangas from Lyse in May $2014 .{ }^{136}$ At that time, Skangas had charters for two LNG carriers, while Skangas and Gasum between them had 20 LNG tanker trucks. Once the share purchase was complete, Gasum contributed its own LNG production plant (opened in 2010 in Porvoo, in Finland) to Skangas. ${ }^{137}$

When it acquired the stake in Skangas, Gasum was owned by the Finnish energy company, Fortum (31 per cent), Gazprom (25 per cent), E.ON (20 per cent), and the Finnish state (24 per cent). In November 2014, it was confirmed that the Finnish state had bought out Fortum and E.ON. ${ }^{138}$ Then, in December 2015, Gazprom sold its 25 per cent stake in Gasum to the Finnish state, bringing Gasum under complete Finnish state ownership. ${ }^{139}$ In June 2017, Gasum increased its stake in Skangas to 70

\footnotetext{
${ }^{128}$ About us, Skangas, 2018. https://www.skangas.com/skangas/about-us/. Sourced on 23 August 2018.

129 'Gasum is new LNG partner', Press release, Lyse, 24 February 2014. www.lysekonsern.no/news-archive/gasum-is-new-Ingpartner-article1645-764.html. Sourced on 23 August 2018.

130 The History of Lyse, Lyse, 2018. www.lysekonsern.no/about-lyse/the-history-of-lyse/. Sourced on 23 August 2018.

${ }^{131}$ Profiles - Skangass, Energy, Oil, and Gas, 2010. www.energy-oil-gas.com/2010/04/12/skangass-as/. Sourced on 23 August 2018.

132 'IMSK - Nordic LNG - a JV created to establish North European LNG market leader - Small-scale LNG - grasping a totally new business opportunity', Press release, I.M.Skaugen, 23 July 2007. https://skaugen.com/wp-content/uploads/2017/11/23July-2007-IMSK-Nordic-LNG-a-JV-created-to-establish-North-European-LNG-market-leader-Small-scale-LNG-grasping-atotally-new-business-opportunity.pdf. Sourced on 23 August 2018.

${ }^{133} 1 \mathrm{H} 2010$ presentation, I.M.Skaugen, 2010. http://skaugen.com/wp-content/uploads/2017/11/14-July-2010-I.M.-Skaugen-SE1H-2010-presentation.pdf. Sourced on 23 August 2018. (See page 6.)

${ }^{34}$ Annual Report 2010 (in Norwegian), Lyse, 2011. www.lysekonsern.no/getfile.php/131224-

1382092717/Dokumenter/lyse \%C3\%A5rsrapport 2010.pdf. Sourced on 30 July 2018. (See page 79.)

${ }^{35}$ Annual Report 2011 (in Norwegian), Lyse, 2012. www.lysekonsern.no/getfile.php/131215-

1382084713/Dokumenter/lyse a\%CC\%8Arsrapport 2011\%20\%2816\%29.pdf. Sourced on 3 August (see page 10).

136 'Gasum Finalizes Skangass Acquisition', LNG World News, 5 May 2014. https://www.Ingworldnews.com/gasum-finalizesskangass-acquisition/. Sourced on 3 September.

137 'Gasum is new LNG partner', Lyse, 2014, op. cit.

138 'Finland takes control of gas utility as seeks to diversify supplies', Reuters, 3 November 2014.

https://www.reuters.com/article/gasum-ma-finland-idUSL6N0ST17K20141103. Sourced on 3 August 2018.

139 'Gasum now 100\% in Finnish ownership', Press release, Gasum, 18 December 2015. https://www.gasum.com/en/Aboutgasum/for-the-media/News/2015/Gasum-now-100-in-Finnish-ownership/. Sourced on 3 September.
} 

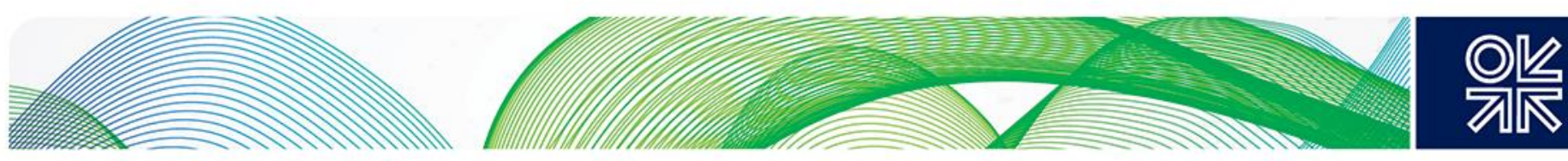

per cent, leaving Lyse with a 30 per cent stake. ${ }^{140}$ Finally, in October 2018, Gasum bought out the remaining Lyse shareholding, to become the sole owner of Skangas. ${ }^{141}$

\section{Major assets and activities}

In terms of major assets, the aforementioned Risavika liquefaction plant in Norway was launched in 2011. It was 100 per cent owned by Lyse, with 100 per cent of the capacity leased to Skangas. ${ }^{142}$ Skangas then acquired the Risavika LNG production plant in April 2016. ${ }^{143}$ In addition to the liquefaction plant at Risavika' 144 , Skangas has developed three small-scale LNG import terminals: Øra Fredrikstad in Norway (2011) ${ }^{145}$, Lysekil in Sweden (2014) ${ }^{146}$, and Pori in Finland (2016). ${ }^{147}$ In terms of its vessels, Skangas charters the Coral Energy small-scale LNG carrier from Anthony Veder (since 2012) ${ }^{148,149}$ and the Coralius LNG bunker vessel from Sirius Shipping (since September 2017). ${ }^{150}$ The Coral Energy was partially subsidised by the Norwegian $\mathrm{NO}_{x}$ Fund. Finally, Skangas added another LNG carrier to its fleet with the launch of the Coral EnergICE in January 2018. In 2017, Skangas carried out more than 1,000 bunkering operations, of which 60 per cent were truck-to-ship in port, 38 per cent were shore (terminal)to-ship, and 2 per cent were ship-to-ship. ${ }^{151}$

In addition to the Skangas-owned LNG terminals, Skangas' parent company, Gasum, is a shareholder in the Tornio Manga LNG terminal. The terminal received its first test delivery in November 2017, and was scheduled for full operation from 'summer 2018'. However, the full launch has not been confirmed, either by Gasum or by Wärtsilä, which built the terminal. The ownership of Skangas by Gasum is important, because Skangas operates the Coral EnergICE 'in order to bring LNG to the Skangas LNG terminal in Pori and the joint venture Manga LNG terminal Tornio in Finland', with the ice-class vessel able to make such deliveries to Tornio year-round. ${ }^{152}$

\section{Analysis}

Although the company was founded in 2007, Skangas took several years to build up its supply chain. Starting with the Risavika LNG export terminal and Øra Fredrikstad LNG import terminal in Norway in

\footnotetext{
140 'Gasum increasing its shareholding in Skangas to 70\%', Press release, Gasum, 22 June 2017.

https://www.gasum.com/en/About-gasum/for-the-media/News/2017/gasum-increasing-its-shareholding-in-skangas-to-70/. Sourced on 3 September.

141 'Gasum consolidates its position as the leading Nordic LNG provider', Press release, Gasum, 10 December 2018. https://www.gasum.com/en/About-gasum/for-the-media/News/2018/gasum-consolidates-its-position-as-the-leading-nordic-Ingprovider/. Sourced on 10 December.

142 Annual report 2014, Lyse, 2015. www.lysekonsern.no/getfile.php/139526-

1434369511/Dokumenter/lyse arsrapport 2014 engelsk.pdf. Sourced on 3 September 2018. (See page 43.)

143 'Risavika LNG production plant under Skangas ownership', Press release, Gasum, 15 April 2016.

https://www.gasum.com/en/About-gasum/for-the-media/News/2016/Risavika-LNG-production-plant-under-Skangas-ownership/. Sourced on 3 September 2018.

144 Skangas terminal, Pori, Skangas, 2018. https://www.skangas.com/supply-chain/terminals--plants/skangas-terminal-pori/. Sourced on 3 September 2018.

145 Skangas terminal, Øra, Skangas, 2018. https://www.skangas.com/supply-chain/terminals--plants/skangas-terminal-ora/. Sourced on 3 September 2018.

${ }^{146}$ Skangas terminal, Lysekil, Skangas, 2018. https://www.skangas.com/supply-chain/terminals--plants/skangas-terminallysekil/. Sourced on 3 September 2018.

${ }_{147}$ Skangas terminal, Risavika, Skangas, 2018. https://www.skangas.com/supply-chain/terminals--plants/liquefaction-plantrisavika/. Sourced on 3 September 2018.

148 'Coral Energy', Skangas, 2018. https://www.skangas.com/supply-chain/shipping-portfolio/coral-energy/. Sourced on 23 August 2018.

149 'Coral Energy', Anthony Veder, 2018. https://www.anthonyveder.com/fleet/coral-energy/. Sourced on 23 August 2018.

150 'Coralius', Skangas, 2018. https://www.skangas.com/supply-chain/shipping-portfolio/coralius/. Sourced on 23 August 2018.

151 'Skangas celebrates milestone with 1,000 LNG bunkering operations in 2017', Press release, Skangas, 19 March 2018. https://www.skangas.com/skangas/news/2018/milestone-with-1000-Ing-bunkering/. Sourced on 3 September 2018.

152 'Coral EnergICE, first Ice Class 1A Super LNG carrier named', Press release, Skangas,. 25 January 2018.

https://www.skangas.com/skangas/news/2018/coral-energice-first-ice-class-1a-super-Ing-carrier-named/. Sourced on 22 August 2018.
} 

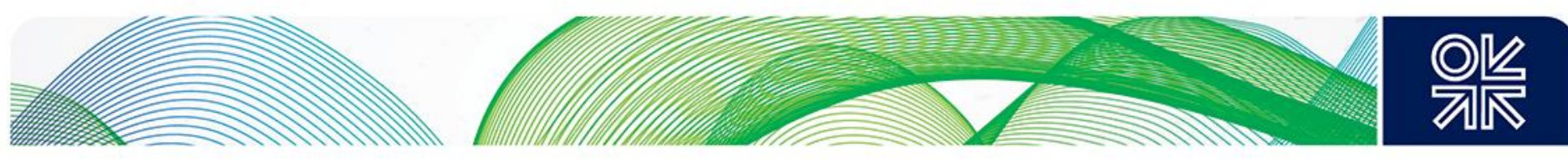

2011, they took on the Coral Energy small-scale LNG carrier in 2012, and launched the Lysekil (2014) and Pori (2016) LNG import terminals, before taking delivery of the Coralius bunker vessel in 2017.

The history of Skangas runs parallel with the development of a regulatory framework limiting $\mathrm{SO}_{x}$ emissions in the North Sea and Baltic Sea region. The founding of Skangas in 2007 coincided with the establishment of sulphur emissions control areas in the Baltic Sea and North Sea in 2006/07, and the introduction of the $\mathrm{NO}_{x}$ tax in Norway. Later, Skangas' investment decisions on the Risavika, Øra Fredrikstad, Lysekil, and Pori LNG terminals, and the decision to invest in the Coral Energy LNG carrier, all followed the 2008 revision of the IMO MARPOL Protocol, and its entry into force in 2010, which substantially tightened restrictions on sulphur emissions in the North Sea/Baltic Sea region. Finally, the January 2015 order of the Coralius vessel by Sirius Veder for operation under long-term charter from Skangas coincided with even tighter restrictions on $\mathrm{SO}_{x}$ emissions in the North Sea/Baltic Sea region, which entered into force in that same month. ${ }^{153}$

By building up this supply chain, Skangas established itself at the forefront of the nascent small-scale regional LNG market, and as the leading provider of LNG bunkering operations, both at its LNG terminals and with its Coralius bunker vessel, in step with the tightening of environmental regulations and the growth in the number of LNG-fuelled ships operating in the region.

\section{AGA and Nauticor (Linde Group)}

\section{Overview and analysis}

AGA is a Swedish specialist in industrial gases and engineering, with a focus on 'the Nordic and Baltic countries'. ${ }^{154}$ It has been part of the German Linde Group since 2000. ${ }^{155}$ AGA is the owner-operator of the Nynäshamn LNG terminal, and owns the Seagas LNG bunker vessel, ${ }^{156}$ which has been operated by Sirius Shipping since its launch in 2013. ${ }^{157,158}$ The Nynäshamn LNG terminal (launched in 2011), with its nominal import capacity of $0.3 \mathrm{bcm} / y e a r$, provided a complement to Sweden's only pipeline source of natural gas - the $2.65 \mathrm{bcm} /$ year connection with Denmark. ${ }^{159,160}$ As noted earlier, the Seagas primarily operates as a source of bunker LNG fuel for the Viking Grace ferry, when it refuels in the port of Stockholm, with the Seagas collecting LNG from the Nynäshamn LNG terminal. ${ }^{161}$ It is notable that, with its launch in 2013, the Viking Grace was the first non-Norwegian vessel in the region to operate on LNG, hence the importance of creating a specific supply chain for its bunkering.

\footnotetext{
153 'LNG newbuilding signed Coralius', Press release, Sirius Veder Gas AB, 15 January2015. www.siriusshipping.eu/wpcontent/uploads/2018/02/20150115-Press-Release-Sirius-Veder-Gas-ordering-LNG-vessel-at-Royal-Bod....pdf. Sourced on 20 August 2018.

154 About AGA, AGA, 2018. www.aga.se/en/all about aga ren/. Sourced on 23 August 2018.

155 'Commission approves the acquisition of AGA (Sweden) by Linde (Germany) subject to conditions', Press release, European Commission, 9 February 2000. http://europa.eu/rapid/press-release IP-00-134 en.htm. Sourced on 23 August 2018.

156 'Sweden: LNG Bunkering Vessel Named in Stockholm', LNG World News, 26 March 2013. https://www.Ingworldnews.com/sweden-Ing-bunkering-vessel-named-in-stockholm/. Sourced on 23 August 2018

${ }^{157}$ LNGF Seagas, Sirius, 2018. http://www.siriusshipping.eu/ship/lngf-seagas/. Sourced on 23 August 2018.

158 'M/S Seagas, the world's first LNG bunkering vessel, uses Oilon's burner system', Press release, Oilon, 30 October 2014. https://www.oilon.com/industry/company/news/seagas-worlds-first-LNG-bunkering-vessel/. Sourced on 23 August 2018.

159 Transmission Capacity map, ENTSOG, 2017. https://www.entsog.eu/maps/transmission-capacity-map. Sourced on 23 August 2018.

160 LNG map 2018, GIE, 2017, op. cit.

161 Seagas facts, AGA, 2018. www.aga.ee/en/products ren/liquefied natural gas/maritime fuel/seagas/index.html. Sourced on 23 August 2018.
} 

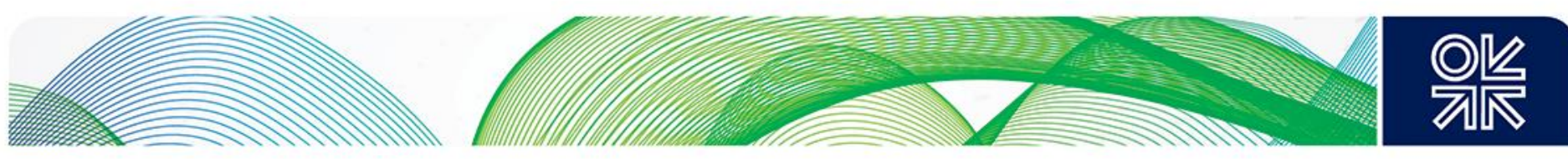

AGA is also developing a small-scale LNG terminal in Finland, at the port of Rauma. Despite financial support from the Finnish government and an expected launch in 2017, the terminal has faced delays following a legal challenge from a local NGO, whose appeal was rejected in April 2018. ${ }^{162,163}$

Nauticor was founded as Bomin Linde LNG in August 2012, as a joint venture between Linde and Bomin, a subsidiary of Mabanaft, itself a subsidiary of the German trading company, Marquard \& Bahls. When Mabanaft acquired Bomin in September 2011, the new company became one of the world's five largest bunkering groups. ${ }^{164}$ The company name was changed from Bomin Linde LNG to Nauticor in March 2017, following Linde's buyout of Marquard \& Bahls in autumn 2016. ${ }^{165}$

It is notable that the press release announcing the creation of Bomin Linde LNG made explicit reference to the IMO SO $\mathrm{SO}_{\mathrm{x}}$ emissions restrictions as a reason for launching the business. In terms of concrete projects, the press release referred to Linde winning the contract to supply LNG as a bunker fuel to the Viking Grace in Stockholm, adding:

This new joint venture underpins our LNG strategy, already visible in our recent opening of the LNG terminal in Stockholm harbour and our study for the introduction of LNG with the Hamburg Port Authority. ${ }^{166}$

In November 2015, Nauticor set up a 90/10 joint venture, Blue LNG, with Klaipedos Nafta. ${ }^{167}$ In October 2016, Blue LNG secured an LNG bunker vessel on a time charter from owner Bernhard Schulte. That vessel, Kairos, was delivered in late 2018, will have the Klaipeda LNG terminal in Lithuania as its home base, and will take advantage of its ice-class construction to provide year-round LNG bunkering across the Baltic Sea region. With a capacity of $7,500 \mathrm{~m}^{3}$, Kairos is the largest purpose-built LNG bunker vessel in the world, and equal in size to the small-scale LNG carrier, Coral Methane, which is currently being modified to enable it to perform ship-to-ship bunkering. 168,169

In addition to its planned operation of a bunker ship from Klaipeda, Nauticor already performs truck-toship bunkering in North-West Europe. The company has performed truck-to-ship bunkering in

\footnotetext{
162 'Finland grants financial support for three LNG terminals', LNG World News, 18 September 2014.

https://www.Ingworldnews.com/finland-grants-financial-support-for-three-lng-terminals/. Sourced on 24 August 2018.

163 'KHO hylkäsi kansalaisten valituksen: Rauman satamaan saa rakentaa LNG-terminaalin' ['The SAC rejected the appeal of citizens: Rauma port should be able to build an LNG terminal'], Yle Uutiset, 13 April 2018. https://yle.fi/uutiset/3-10158418. Sourced on 24 August 2018.

164 About us: History, Bomin, 2018. https://www.bomin.com/en/about-us/history.html. Sourced on 24 August 2018.

165 'Bomin Linde LNG to Become Nauticor', Press release, Nauticor, 30 March 2017.

https://nauticor.de/ upl/de/ d/pr bomin linde to become nauticor.pdf. Sourced on 24 August 2018.

166 'Marquard \& Bahls' Subsidiary Bomin and Linde to Establish Joint Venture in Liquefied Natural Gas for the Marine Market',

Press release, Bomin, 6 August 2012. https://www.bomin.com/en/news-info/press-releases/details/article/marquard-bahls-

subsidiary-bomin-and-linde-to-establish-joint-venture-in-liquefied-natural-gas-for.html. Sourced on 24 August 2018.

167 'Bomin Linde LNG and Klaipedos Nafta Establish Joint-Venture for LNG Bunker Supply Vessel', Press release, Nauticor, 24 November 2015. https://nauticor.de/ upl/de/ d/151124 pr jv v4 vf.pdf. Sourced on 24 August 2018.

168 'Bomin Linde LNG secures world's largest liquefied natural gas bunker supply vessel', Press release, Nauticor, 11 October

2016. https://nauticor.de/ upl/de/ d/161011 pr bllng orders largest Ing bsv vf.pdf. Sourced on 24 August 2018.

169 'Kairos set to augment nascent LNG bunker vessel pool', LNG World Shipping, 16 August 2018.

https://www.Ingworldshipping.com/news/view,kairos-set-to-augment-nascent-Ing-bunker-vessel-pool 53921.htm. Sourced on

24 August 2018.
} 

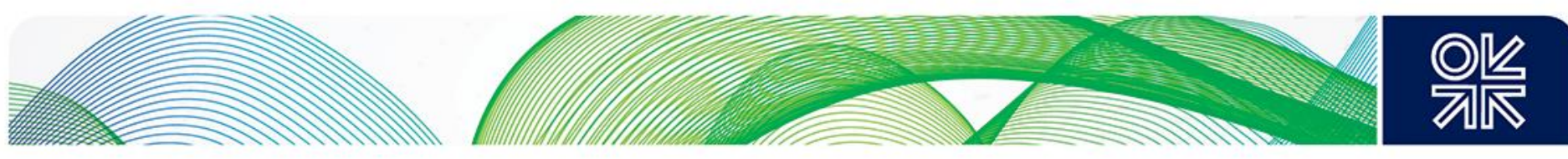

Bremerhaven, ${ }^{170}$ Rostock, ${ }^{171}$ Moerdijk, ${ }^{172}$ Brünsbuttel, ${ }^{173}$ and Rotterdam. ${ }^{174}$ Nauticor's participation in the regional LNG bunker market demonstrates two key factors: the growth in the number of nonNorwegian vessels operating on LNG in the region since 2013, and the value for a supplier of having a contract for regular supplies to specific vessels.

For example, in Bremerhaven, Nauticor began its regular bunkering of the ropax ferry, MS Ostfriesland, under long-term agreement with the vessel owner, AG EMS. Likewise, Nauticor's bunkering of the Fure West chemical tanker in Rostock is conducted under long-term agreement with the Swedish ship owner Furetank Rederi, signed in October 2016. ${ }^{175}$ Since May 2018, Nauticor has also provided LNG bunker fuel for the Fure Vinga chemical tanker for Furetank Rederi, and since October 2018 has provided LNG bunker fuel for the Haaga and Viiki bulk carriers, owned by ESL shipping. ${ }^{176,177}$ The latter account for two of the four LNG-fuelled bulk carriers currently in operation in Europe.

Such operations are, in essence, similar to AGA's regular bunkering of the Viking Grace, using the Seagas bunker vessel and LNG from the Nynäshamn LNG terminal, in the sense that they are regular bunkering operations conducted under a long-term agreement. It is also notable that, with their launches in 2015, the Ostfriesland and Helgoland ferries owned by AG EMS were the third and fourth nonNorwegian passenger ferries to operate on LNG in the region. While the fifth - the Prinsesse Isabella operated by Samsø Municipality in Denmark - is bunkered with locally-produced liquefied biogas, the sixth, the Tallink Megastar, is bunkered by Eesti Gaas and has operated between Tallinn and Helsinki since 2017. Following a successful first year, Eesti Gaas and Tallink signed a five-year bunker fuel contract in March 2018. ${ }^{178}$ Finally, the Visborg ferry, owned by the Swedish Destination Gotland - will also be bunkered by Nauticor, from its expected launch in February 2019.179

\section{Fluxys and Gasunie}

As the owner-operator of the Zeebrugge large-scale LNG import terminal, Fluxys commissioned a second jetty specifically for loading small-scale LNG carriers and bunker vessels in 2016, and holds a

\footnotetext{
170 'Bomin Linde LNG Fuels the First German Vessel with Liquefied Natural Gas', Press release, Nauticor, 15 May 2015. https://nauticor.de/ upl/de/ d/150505 pr bllng erstbetankung eng.pdf and 'Successful launch and initial bunkering of the first container ship with an engine converted for the use of LNG', Press release, Nauticor, 24 August 2017. https://nauticor.de/ upl/de/ d/20170824 nauticor pressemitteilung erstbefuellung wes amelie englisch final.pdf. 171 'First bunkering of an LNG-fuelled chemical tanker in German Port', Press release, Bomin Linde LNG, 6 February 2017. https://nauticor.de/ upl/de/ d/20170206 pr bomin linde Ing first bunkering germany-4.pdf.

2 'Nauticor has conducted the first parallel LNG bunkering with two trucks for a container ship in Europe', Customer notification, Nauticor, 11 September 2017.

https://nauticor.de/ upl/de/ d/20170911 nauticor first parallel Ing bunkering with two trucks for a container ship in euro pe.pdf.

173 'Nauticor's LNG bunker operation for the Scheldt River in Brunsbüttel sets new milestone for establishing LNG as fuel for ships in the Lower Elbe region', Press release, Nauticor, 13 February 2018.

https://nauticor.de/ upl/de/ d/20180213 brunsbu ttel ports nauticor pm Ing bunkering scheldt river.pdf.

74 'Nauticor extends its LNG supply network for ships in the North Sea and sets new speed record for bunker operations in the Port of Rotterdam', Press release, Nauticor, 22 February 2018.

https://nauticor.de/ upl/de/ d/20180222 nauticor press release start of Ing bunker operations in rotterdam english.pdf.

175 'Bomin Linde LNG and Swedish shipping company Furetank Rederi establish LNG partnership', Press release, Nauticor, 25 October 2016. https://nauticor.de/ upl/de/ d/161024 pr bomin linde Ing loi furetank vf.pdf.

176 'Nauticor and Gas Natural Fenosa cooperate in first LNG bunkering of Fure Vinga in Europe', Press Release, 22 May 2018. https://nauticor.de/ upl/de/ d/22052018 ndp nauticor y gnf bunkering eng.pdf. Sourced on 11 January 2019.

77 'ESL and Nauticor sign long-term LNG supply contract for the world's first bulk carriers

"Haaga" and "Viikki" running on the alternative fuel', Press Release, 25 October 2018.

https://nauticor.de/ upl/de/ d/20181025 nauticor esl long term Ing supply contract.pdf. Sourced on 11 January 2019.

178 'Eesti Gaas will supply megastar vessel with LNG during the following five years', Press release, Eesti Gaas, 6 March 2018. https://www.gaas.ee/en/eesti-gaas-will-supply-megastar-vessel-with-Ing-during-the-following-five-years/. Sourced on 24 August 2018.

179 'Sweden's Destination Gotland christens LNG ferry', LNG World News, 14 December 2018.

https://www.Ingworldnews.com/swedens-destination-gotland-christens-first0-Ing-ferry/. Sourced on 11 January 2019.
} 

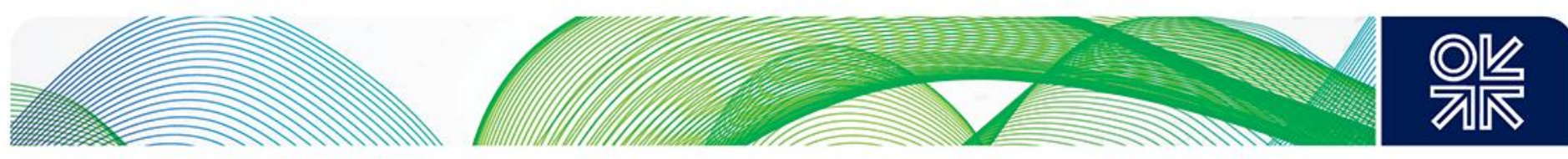

stake in the Zeebrugge-based ENGIE Zeebrugge bunker vessel, which was launched in February 2017. At the Dunkerque large-scale LNG import terminal (launched in January 2017), Fluxys holds a 25 per cent stake. In June 2018, Fluxys and its two consortium partners (AXA and Credit Agricole) purchased an additional 35 per cent stake, giving Fluxys an effective stake of approximately 30 per cent. ${ }^{180}$ Truckloading operations are being developed at the Dunkerque LNG terminal, with an intended launch in early 2019, while a Final Investment Decision (FID) is planned for mid-2019 on the adaptation of the terminal jetty to allow the reception of small-scale LGN carrier (between $5,000 \mathrm{~m}^{3}$ and $30,000 \mathrm{~m}^{3}$ ), thus allowing the terminal to participate in break-bulk and small-scale reload activities. ${ }^{181}$

Gasunie is a 50 per cent shareholder in the Gate LNG terminal in Rotterdam, which was opened in 2011. The remaining 50 per cent is controlled by another Dutch company, Vopak. ${ }^{182}$ In 2016, a third jetty at the Gate terminal was opened specifically for loading small-scale LNG carriers and LNG bunker vessels. ${ }^{183}$ In H1 2018, Gasunie and Vopak, along with Oiltanking (a subsidiary of Marquard \& Bahls) held a successful 'open season' for a planned $5 \mathrm{bcm}$ capacity LNG import terminal at Brünsbuttel, in Germany. Gasunie hopes to take an FID by the end of 2019, and plans for the new terminal to offer truck-loading and shore-to-ship LNG bunkering services. ${ }^{184}$

\title{
Comparing the business strategies of different bunker fuel suppliers
}

When comparing the business models of these companies, certain similarities can be identified. In a 2016 interview with LNG World Shipping, the Chief Executive of Nauticor, Mahinde Abeynaike, explained the value of investing in a large bunker vessel and its Klaipeda-based Blue LNG joint venture:

\begin{abstract}
Initially, our focus was on landside storage solutions but it became clear that providing mobility of supply has priority, in particular in the early phase of the market. It's also been about having direct access to a hub - a terminal capable of receiving large LNG carriers, and having from that hub the distance or proximity to the delivery point. That distance needs to be as short as possible to offer commercially attractive prices. ${ }^{185}$
\end{abstract}

For comparison, Skangas has a hub at the Risavika LNG export terminal and the Coralius bunker vessel; Gasnor has the Snurrevarden and Kollsnes LNG export terminals as its hubs and the Pioneer Knutsen as its bunker vessel. Gasnor's parent company, Shell, uses the Gate Rotterdam LNG terminal is its hub, while its bunker vessel, Cardissa, will soon be complemented by the modified Coral Methane. In each case, the company has secured access to LNG at a 'hub' and a bunker vessel that allows geographically flexible bunkering across the region. While Gasnor has the most limited scope, Skangas has extended its value chain across the region with its two small-scale LNG carriers (Coral Energy and Coral Energ/CE) and small-scale LNG import terminals (at Lysekil in Sweden and Pori in Finland) that also act as 'mini hubs'. While Shell will depend on third-party access to LNG terminals (primarily Gate Rotterdam), its two relatively large-capacity bunker vessels reflect the scope of its ambition, regarding both its bunkering contracts with Sovcomflot and Carnival Corp, and its own need for LNG bunker fuel.

\footnotetext{
180 'Dunkirk LNG terminal to become part of the Fluxys group', Press release, Fluxys, 29 June 2018. https://www.fluxys.com/group/en/NewsAndPress/2018/180629 press Dunkirk. Sourced on 24 August 2018.

'Dunkirk positions itself for growing European LNG bunker market', LNG World Shipping, Martin, E., 26 November 2018. https://www.Ingworldshipping.com/news/view,dunkirk-positions-itself-for-growing-european-Ing-bunker-market 56004.htm. Sourced on 13 December 2018.

182 Partners, Gate LNG, 2018. http://gate.nl/en/gate-terminal/partners.html. Sourced on 24 August 2018.

183 'Gate terminal celebrates opening new LNG facilities', Press release, Gate LNG, 1 December 2018. http://gate.nl/en/media/news/newsdetail/gate-terminal-celebrates-opening-new-lng-facilities.html. Sourced on 24 August 2018.

184 'Market responds positively to first German LNG import terminal', Press release, Gasunie, 3 May 2018. https://www.gasunie.nl/en/news/market-responds-positively-to-first-german-Ing-import-terminal. Sourced on 24 August 185 'Size and scale "are critical” to LNG bunker supply ships, says Bomin Linde LNG boss' LNG World Shipping, 12 October 2016. https://nauticor.de/ upl/de/ d/161012 Ingworldshipping size and scale.pdf. Sourced on 24 August 2018.
} 

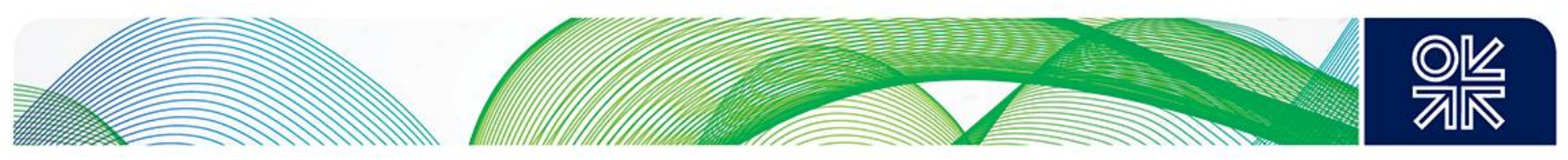

Similarly, Fluxys has Zeebrugge as its 'hub', and the ENGIE Zeebrugge as its flexible bunker vessel. Although the ENGIE Zeebrugge operates primarily in Zeebrugge, in October 2017 the owners of the ENGIE Zeebrugge (the Gas4Sea consortium, of which Fluxys is a member) agreed to supply LNG as a marine fuel to four crude oil tankers operated by Statoil, with the fuel to be delivered in Rotterdam. ${ }^{186}$ By contrast, Gasunie has the Gate terminal as its 'hub', but lacks a bunker vessel that could provide flexibility of bunker services. Fluxys and Gasunie are similar in that they are operators of large-scale LNG terminals (at Zeebrugge and Rotterdam, respectively), both have invested in small-scale jetties at their LNG terminals, and both have sought expansion in a neighbouring country through fixed terminalbased infrastructure (in Dunkerque and Brünsbuttel, respectively).

\section{Vessel owner-operators as consumers of LNG as bunker fuel}

\section{Ferry companies}

Between 2006 and 2012, the Norwegian ferry line, Fjord1, launched 11 LNG-fuelled ferries, to complement its first LNG ferry, the Glutra (launched in 2000), leaving the company with 12 LNG ferries today. The other Norwegian ferry companies operating LNG-fuelled ferries are:

- Tide Sjø (three ferries all launched in 2009),

- Torghatten Nord (four ferries, all launched in 2012-13),

- Fjordline (two ferries launched in 2013),

- FosenNamsos Sjø (one ferry launched in 2010),

- Norled (two ferries, both launched in 2013), and

- Boreal Transport (two ferries launched in 2015).

After the Glutra, the launch of a further 25 LNG-fuelled ferries between 2006 and 2015 in Norway was surely influenced by both the designation of the Baltic Sea and North Sea as SO ECAs in 2006/07, and the introduction of the Norwegian NOx tax in 2007 and NOx Fund in 2008. This is because, while some of the ferries concerned only operate in Norwegian waters, others serve routes between Norway, Sweden, and Denmark.

Outside Norway, Samsø Municipality (Denmark), Viking Line (Finland), AG EMS (Germany - two vessels), and Tallink (Estonia) are the only four ferry companies operating in the North Sea/Baltic Sea ECAs to launch LNG-fuelled ferries, with all five vessels having been launched in the period 2013-17.

Of these 26 Norwegian and five non-Norwegian ferries, only the Tresfjord (Fjord1) and MS Ostfriesland (AG EMS) were retrofit projects - the others were all newbuilds. ${ }^{187}$ This suggests that LNG-fuelled ferries in the region are being 'phased in' as part of the regular vessel turnover, with ferry owners prepared to pay a premium for low-sulphur marine gasoil to comply with regional ECA regulations, until their vessels are due for replacement. Indeed, 17 more LNG-fuelled ferries are under construction for delivery in 2018-20, for operation in the North Sea/Baltic Sea ECAs (by Rederi Gotland, Torghatten, Fred Olsen, Royal Doeksen, Stena, Viking Line, Clyde and Hebrides Ferry Service (CHFS), Polish Baltic Shipping Company, and Brittany Ferries).

\footnotetext{
186 'Gas4Sea partners land Rotterdam LNG bunker-supply deal', LNG World Shipping, 11 October 2017. https://www.Ingworldshipping.com/news/view,gas4sea-partners-land-rotterdam-Ing-bunkersupply-deal 49472.htm. Sourced on 24 August 2018.

${ }^{187}$ Alternative Fuels Insight platform, DNV GL, 2019, op. cit.
} 

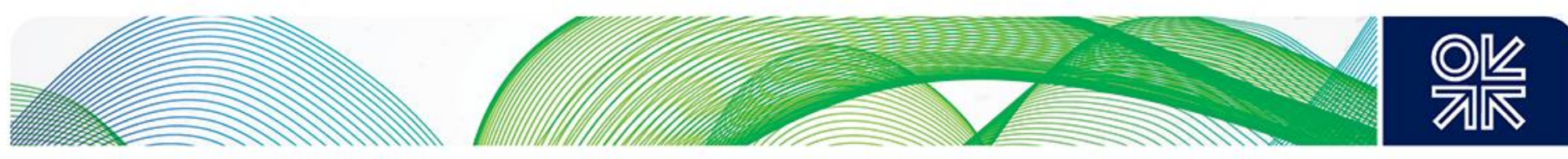

\section{Shipping companies}

The 2015 tightening of $\mathrm{SO}_{x}$ emissions restrictions also acted as a watershed for LNG-fuelled cargo shipping in Northern Europe: eight of Norway's 13 LNG-fuelled cargo vessels were launched in 2015 or later, while for the rest of Europe that ratio is 18 out of 20 . A common refrain from shipping companies whose vessels operate continuously in the North Sea/Baltic Sea ECAs is that LNG represents a path to compliance with $\mathrm{SO}_{x}$ emissions restrictions.

For example, at present, there is only one LNG-fuelled container ship operating in Europe: the Wes Amelie, relaunched in September 2017 with a capacity of 1,036 twenty-foot equivalent units (TEUs). The Wes Amelie was the world's first container ship to be retrofitted to LNG propulsion. According to the Wessels Reederei General Manager, Christian Hoepfner:

Wes Amelie operates in the highly regulated Nordic and Baltic Seas. Since they are both within emission control areas, the ship needs to meet the highest environmental standards and strictest limits for emissions. By converting to a low emission fuel, we are safeguarding the future of this container ship as well as our own competitiveness in the market. ${ }^{188}$

Similarly, the Finnish container shipping company, Containerships, has four LNG-fuelled container ships with capacities of 1,400 TEU under construction. The first was delivered in December 2018, and is due to begin operations in Q1 2019. The three remaining vessels are due for delivery in 2019. ${ }^{189}$ The procurement process began in 2012, and in May 2018, the Containerships CEO, Kari-Pekka Laaksonen, offered an explanation that surely resonates with other ship owner/operators in the region:

When we began the project, we were already aware of the upcoming emissions restrictions in the SECA [SO $\mathrm{ECA}$ ]. We thought about how we could stay within emissions limits that are becoming increasingly strict over the short and long term. We needed a sensible solution to cover the vessel's entire service life, which is about 25 years... Sulphur scrubbers and low-sulphur marine diesel oil enable sulphur dioxide emissions to be reduced, but they have little effect on any other emissions. Switching to LNG also enables a substantial reduction in carbon dioxide, nitrogen [NOx] and particulate emissions. The new vessel must satisfy increasingly strict environmental norms for a long time into the future. ${ }^{190}$

In 2016, United European Car Carriers (UECC) took delivery of the world's first LNG-fuelled Pure Car and Truck Carriers (PCTCs), the Auto Eco and Auto Energy - a pair of vessels that also operate continuously in the North Sea/Baltic Sea ECAs. In a manner similar to ferry and container shipping companies with regular routes and bunkering agreements, UECC has an exclusive contract with ENGIE for bunker fuel, provided since June 2017 by the ENGIE Zeebrugge at the Zeebrugge LNG terminal. ${ }^{191}$

Although LNG-fuelled cargo shipping is more prevalent among vessels operating continuously in an ECA, recent developments suggest that LNG-fuelled shipping is gaining traction among intercontinental shippers. In November 2017, the French shipping company, CMA CGM, announced that it

\footnotetext{
188 'An LNG first as container ship Wes Amelie converts to dual-fuel', LNG World Shipping, 22 September 2017. https://www.Ingworldshipping.com/news/view,video-an-Ing-first-as-container-ship-wes-amelie-converts-to-dualfuel 49256.htm. Sourced on 24 August 2018.

189 'Containerships receives its first LNG-powered container vessel', Press Release, 13 December 2018. http://www.containershipsgroup.com/news/company-news/containerships-receives-its-first-Ing-powered-container-vessel Sourced on 11 January 2019.

190 'Containerships selects LNG', Port of Helsinki Magazine, 29 May 2018. https://www.portofhelsinki.fi/en/emagazine/containerships-selects-Ing. Sourced on 24 August 2018.

1 'LNG car carrier takes the plunge: interview with Glenn Edvardsen', Smedley, M., Natural Gas World Magazine, 18 October 2017. https://www.naturalgasworld.com/magazine-article-uecc-55740. Sourced on 24 August 2018.
} 

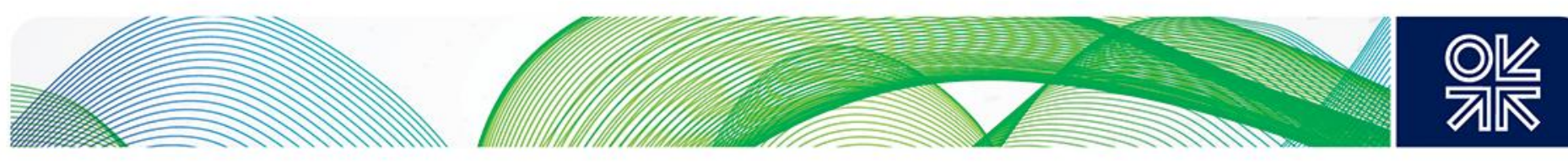

had ordered nine large, new LNG-fuelled container ships with capacities of 22,000 TEUs. ${ }^{192}$ According to LNG World Shipping:

They will be the largest container ships ever built and the first vessels of their type to operate on LNG... The ships - which will be on the Asia-Europe route - will be fitted with LNG tanks that will have a capacity of $18,000 \mathrm{~m}^{3}$. $^{193}$

For context, each of the giant container ships has a fuel tank more than twice the capacity of the world's current-largest LNG bunker vessel (the 7,500 $\mathrm{m}^{3}$ Kairos).

In another example of the importance of underpinning LNG bunkering with a long-term contract (in a newly developing market), in December 2017 CMA CGM signed a contract with Total for the provision of 300,000 tonnes a year of LNG as a bunker fuel, for ten years from 2020. ${ }^{194}$ Again, for context, that volume is equal to the entire annual LNG production of the Skangas LNG export terminal at Risavika. Then, in February 2018, Total announced that it had signed an agreement with Mitsui O.S.K. Lines, Ltd. (MOL) for the long-term charter of a large LNG bunker vessel, with a capacity of $18,600 \mathrm{~m}^{3}$, to operate in Northern Europe and fulfil the bunkering contract between Total and CMA CGM. ${ }^{195}$

Finally, in June 2018, CMA CGM agreed to purchase Containerships, to boost its short-sea shipping presence in Northern Europe and the Baltic Sea. ${ }^{196}$ CMA CGM will become a leader in LNG-fuelled container shipping, both within the North Sea/Baltic Sea region, and between Northern Europe and Asia. With its regular schedules, container shipping is a promising sector for LNG bunkering, and could act as a 'proving ground' for the viability of inter-continental LNG-fuelled shipping.

\section{Analysis of consumer behaviour}

First of all, it is clear that the willingness of ship owners/operators to switch to LNG as a bunker fuel was substantially influenced by the tightening of emissions regulations. This occurred first in Norway from 2007-08 onwards (in line with the domestic NOx restrictions), and then in the North Sea/Baltic Sea ECAs in light of the substantial tightening of $\mathrm{SO}_{\mathrm{x}}$ emissions restrictions from 2015 . Secondly, a common trend among consumers is to ensure a contract for regular bunkering operations with a reliable supplier - an approach that is more feasible for vessels with regular schedules and bunkering stops. On this basis, the growth in LNG-fuelled shipping offers opportunities for the sale of LNG as a bunker fuel to the smaller, entrepreneurial, companies (Gasnor, Skangas, and Nauticor) and to larger energy companies that have recognised the market development (Shell, Fluxys, Gasunie, Eesti Gaas, ENGIE, and Total).

The growth of opportunities for consumers to secure LNG supplies is tied to the development of the physical infrastructure for LNG bunkering, including the 'hub and vessel', shore-to-ship, and truck-toship bunkering methods. Finally, the chronology noted above illustrates the extent to which ferries (with

\footnotetext{
192 'World Innovation: CMA CGM is the first shipping company to choose liquefied natural gas for its biggest ships', Press release, CMA CGM, 7 November 2017. www.cma-cgm.com/news/1811/world-innovation-cma-cgm-is-the-first-shippingcompany-to-choose-liquefied-natural-gas-for-its-biggest-ships. Sourced on 24 August 2018.

193 'LNG fuel design and build partnership highlighted at SMM', Bergman, J., LNG World Shipping, 24 August 2018. https://www.Ingworldshipping.com/news/view,cma-cgm-orders-spawn-Ing-fuel-design-and-build-partnership 54003.htm. Sourced on 24 August 2018.

194 'Strategic Agreement between Total and CMA CGM on Liquefied Natural Gas Fuel Supply for CMA CGM New Build Container Ships', Press release, Total, 4 December 2017. https://www.total.com/en/media/news/press-releases/StrategicAgreement-between-Total-and-CMA-CGM-on-Liquefied-Natural-Gas-Fuel-Supply-for-CMA-CGM-New-Build-Container-Ships. Sourced on 24 August 2018.

195 'Total and Mitsui O.S.K. Lines sign a long-term charter contract for a pioneer Liquefied Natural Gas (LNG) bunker vessel', Press release, Total, 6 February 2018. https://www.total.com/en/media/news/press-releases/total-and-mitsui-osk-lines-sign-along-term-charter-contract-for-a-pioneer-liquefied-natural-gas-bunker-vessel.

196 'Finland's Containerships pushing on with LNG strategy', LNG World News, 16 August 2018.

https://www.Ingworldnews.com/finlands-containerships-pushing-on-with-Ing-strategy/. Sourced on 24 August 2018.
} 

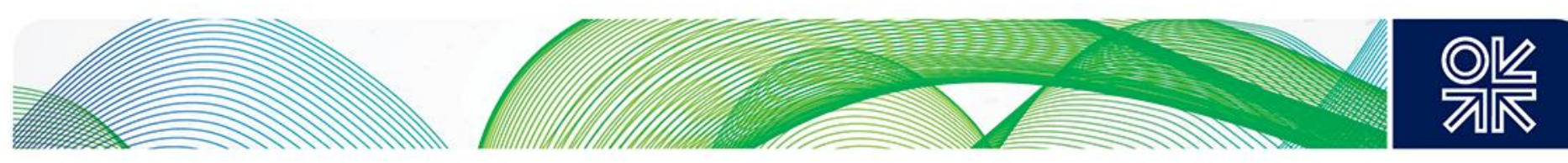

their fixed schedules) were the 'first movers' in adopting LNG propulsion, followed by cargo vessels that operated almost exclusively in the North Sea/Baltic Sea ECAs. The decision of CMA CGM to choose LNG propulsion for its container ships, with fuel tanks large enough to sustain the vessels all the way from Asia to Europe, is a sign that the impending tightening of global $\mathrm{SO}_{\mathrm{x}}$ emissions restrictions from January 2020 onwards is now influencing shipping companies that operate beyond the regional ECAs.

However, the fact remains that, relative to the size of the regional fleet, the ship owners who have chosen to invest in LNG-fuelled vessels are in the minority. By comparing the size of the LNG-fuelled fleet with data from UNCTAD and Marine Traffic for the total regional fleet, just 1 per cent of vessels in the North Sea/Baltic Sea region are LNG-fuelled. The explanation for this is multi-faceted:

a) The prohibitive cost of retrofitting appears to limit LNG to newbuild vessels. This means that LNG-fuelled vessels will only be gradually phased into the regional fleet, in the manner discussed earlier. With vessel lifespans of 20-30 years (shorter in some cases), this vessel turnover will continue for a long time.

b) Outside Norway, the infrastructure to support LNG bunkering has only been substantially developed in the last five to seven years. Therefore, ship owners' growing confidence in the regional availability of $L N G$ as a bunker fuel is also a recent development.

c) The tightening of $\mathrm{SO}_{x}$ emissions restrictions in 2015 forced ship owners to adapt, but LNG was just one of several options available - the others being the installation of a scrubber or the purchase of low-sulphur marine gasoil. That choice was between higher capital investment (for LNG or scrubbers) or higher fuel costs (for LSMGO). Unfortunately for LNG, it was the more expensive of the two capital investment options, meaning that scrubber uptake was more popular. More popular still was the 'wait and see' approach of running on LSMGO until the market landscape becomes clearer.

Looking forward, the supply-side expansion of regional LNG bunkering infrastructure beyond smallscale truck-to-ship bunkering to new, larger, bunker ships and port-to-ship bunkering will boost the availability of LNG bunker fuel, while the January 2020 changes will enhance the attractiveness of LNG for ships that spend a significant portion of their time outside the ECAs, and the introduction of $\mathrm{NO}_{x}$ emissions restrictions in the North Sea/Baltic Sea ECAs will certainly make LNG more attractive for new vessels spending time inside the ECA. For these reasons, from 2020 onwards, the 'wait and see' period will be over, and the rate of growth of LNG-fuelled shipping in Northern Europe and beyond will increase.

\section{Conclusions}

The initial development of a complete LNG supply chain in the North Sea and Baltic Sea Emissions Control Areas was not a direct response to the tightening of IMO restrictions on sulphur and $\mathrm{NO}_{x}$ emissions from shipping. Rather, the development of large-scale LNG terminals between 2005 and 2018 was largely driven by a desire for access to a growing global LNG market as a complement (or, in some cases, an alternative) to pipeline natural gas supplies. Likewise, the development of smallscale LNG terminals in the region occurred primarily to service non-transportation natural gas demand (particularly for power generation and industrial consumption) in off-grid locations.

However, once the availability of $\mathrm{LNG}$ supplies to the region was established, the limits on $\mathrm{NO}_{x}$ and $\mathrm{SO}_{x}$ emissions from shipping made the provision of LNG as a bunker fuel an attractive commercial proposition, given that ship owners were obliged to respond to those emissions regulations in some way. This view has been put forward by the Chairman of SEA/LNG, Chris Keller, who stated: 

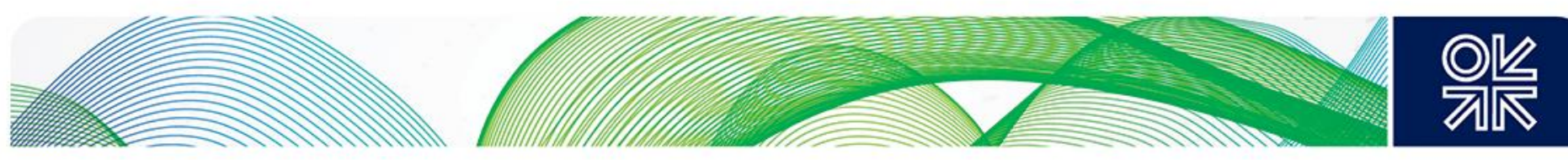

The bulk LNG infrastructure is largely built, what remains is the last mile, in which the industry is showing a growing appetite to invest. ${ }^{197}$

As a reminder, an explanation of the different methods of LNG bunkering are provided in Appendix 1 . Initially, the development of truck-loading facilities in the region's LNG terminals coincided with the development of technology enabling flexible LNG bunkering direct from trucks to ships. This avoided the necessity of investing in fixed shore-to-ship bunkering infrastructure, which was perceived as more of a commercial risk in the early stages of market development.

In parallel with the increased availability of $L N G$ as a bunker fuel, the owners/operators of ships that spent the vast majority of their time in the North Sea/Baltic Sea ECAs (such as PSVs and ferries) began to choose LNG propulsion for their newbuild vessels. As the market developed further, and demand for LNG as a bunker fuel grew, commercial suppliers felt confident enough to invest in bunker vessels and shore-to-ship bunkering infrastructure. Thus, a virtuous circle began to develop, as more substantial bunkering infrastructure enabled the supply of LNG bunker fuel to a greater number of larger vessels.

Therefore, while the arrival of large and small-scale LNG supplies in the region was not a direct response to shipping sector environmental regulations, the first major conclusion to draw is that the ongoing growth of LNG as a marine shipping fuel in the North Sea and Baltic Sea region has been overwhelmingly policy driven. This relates firstly to the Norwegian government restrictions on $\mathrm{NO}_{x}$ emissions, secondly to the introduction (and subsequent tightening) of $\mathrm{SO}_{x}$ restrictions in the North Sea/Baltic Sea ECAs, and thirdly to EU regulations of $\mathrm{SO}_{x}$ emissions from passenger vessels in EU waters. When the global $\mathrm{SO}_{x}$ emissions cap is tightened in January 2020, and restrictions on $\mathrm{NO}_{x}$ emissions by newbuild vessels in the North Sea/Baltic Sea ECAs take effect in January 2021, a similar influence is likely to be observed, as ship owners are forced to adapt.

This policy 'push' has been accompanied by the 'pull' of increasing availability of LNG bunkering infrastructure in the North Sea/Baltic Sea region. As the development of large-scale LNG import terminals brought LNG supplies to the regional market, the ramp-up of small-scale Norwegian LNG exports and the launch of break-bulk facilities in the region's large-scale LNG terminals provided a supply of small-scale LNG deliveries to the growing number of small-scale regional LNG import terminals. In addition to the opening of LNG bunkering facilities in the region's large and small-scale LNG terminals, the launch of truck-loading facilities at these terminals (and the loading of new LNG bunker vessels) made it commercially feasible to deliver LNG to maritime ports proximate to those terminals, for provision to vessels as bunker fuel.

The second major conclusion to draw is that while LNG propulsion is proving attractive to ship owners investing in newbuild vessels that will operate in the North Sea/Baltic Sea ECAs, LNG propulsion has not proved so attractive to the owners of existing vessels. Rather, their response to has been to invest in scrubbers or (more often) to simply switch to the more expensive low-sulphur marine gasoil. This latter option - with lower capex and higher opex costs - is essentially a 'wait and see' response.

The impending tightening of global restrictions on $\mathrm{SO}_{\mathrm{x}}$ emissions from shipping will provide a policy 'push' similar to that seen in the North Sea/Baltic Sea ECAs; ship owners will be obliged to react in one way or another. The lessons of the North Sea/Baltic Sea ECAs suggests that LNG may be attractive for newbuild vessels, particularly if the cost of LNG as a shipping fuel is substantially below that of lowsulphur marine gasoil and low-sulphur fuel oil, but only if sufficient supplies of LNG bunker fuel are available.

Another lesson to draw from this case study is that shipping sector environmental regulations can change several times during the life of a vessel. In the North Sea/Baltic Sea region, $\mathrm{SO}_{x}$ emissions were

\footnotetext{
197 'LNG bunkering vessels to double by 2020', LNG World News, 25 May 2018. https://www.Ingworldnews.com/lng-bunkeringvessels-to-double-by-2020/. Sourced on 18 July 2018.
} 

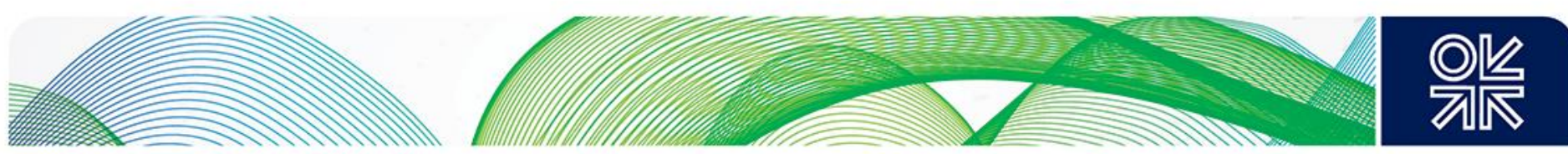

introduced and then tightened twice in the space of a decade between 2005 and 2015, while restrictions on $\mathrm{NO}_{x}$ emissions for newbuild vessels were introduced in 2000, were tightened in 2010, and are set to tighten substantially in 2021. Given that vessels have operating lifetimes of several decades, the potential for further tightening of environmental regulations is sure to give ship owners pause for thought, as they consider how to 'future proof' their vessels. Therefore, when considering existing vessels, we may expect a surge in demand for low-sulphur marine gasoil and IMO-compliant lowsulphur fuel oil blends in 2020/21, as a result of the 'wait and see' approach adopted by many ship owners/operators. Then, over time, this may give way to a gradual uptake of LNG propulsion as new vessels are phased into the fleet.

Therefore, a final conclusion to draw is that the substantial tightening of IMO restrictions on $\mathrm{SO}_{\mathrm{x}}$ emissions at a global level from 2020 is unlikely to trigger a huge surge in LNG demand for bunkering as ship owners race to retrofit their vessels. However, LNG demand for bunkering may grow steadily over the coming decade, as a number of ship owners choose LNG for their newbuild vessels and phase out their vessels fuelled by oil products, while LNG bunkering services also become more widely available. In short, LNG-fuelled shipping may be 'phased in' over an extended period, in a manner that reflects the long lifespans and low turnover of vessels. 

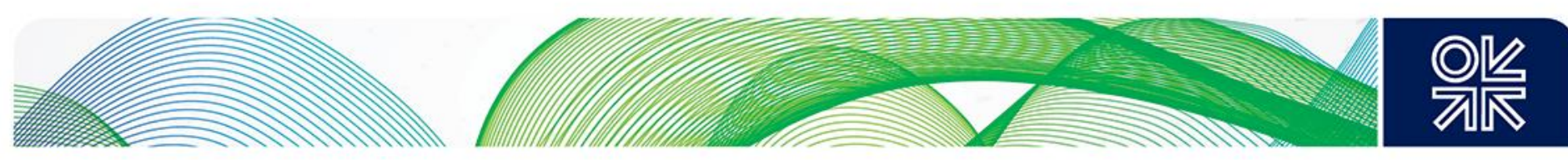

\title{
Appendix 1: LNG bunkering methods
}

Below is an explanation of the different methods of loading vessels with LNG as a bunker fuel. The key elements are 1) the capacity of the storage tank from which the vessel is bunkered, and 2) the flow rate, which indicates how much LNG may be transferred from the storage tank to the vessel's fuel tank.

\section{Truck-to-ship (TTS)}

The most flexible form of refuelling (or 'bunkering') ships with LNG is the 'truck-to-ship' (TTS) method. In this case, an LNG road tanker pulls alongside the ship in port, and is connected to the ship with a flexible hose. The LNG is then transferred from the truck to the ship. This option is attractive because it requires very little infrastructure (and, therefore, capital investment), and the road tanker can also be used for delivering LNG to other destinations. However, the major limitation of TTS bunkering is the limited capacities of $L N G$ road tankers $\left(40-80 \mathrm{~m}^{3}\right.$ of $\left.L N \mathrm{G}^{198}\right)$. Given the conversion ratios offered by the International Gas Union (IGU), a road tanker with a capacity of $40-80 \mathrm{~m}^{3}$ of LNG has a capacity of 1836 tonnes of LNG, or $23,400-46,800 \mathrm{Nm}^{3}$ of natural gas. ${ }^{199,200}$

A further drawback of truck-to-ship bunkering is the limited flow rate, of around 40-60 $\mathrm{m}^{3}$ of LNG per hour (900-1,200 litres per hour). While the aforementioned volumetric capacity limitation may be overcome by bunkering from several trucks sequentially, the limited flow rate may be overcome by bunkering from two or more trucks at the same time, using a common manifold. However, bunkering from several trucks in parallel may impede loading/unloading activities at the dockside. ${ }^{201}$

\section{Ship-to-ship (STS) using bunker barges and bunker vessels}

The next step up in terms of volumetric capacity and flow rate is 'ship-to-ship' (STS) bunkering, using bunker barges and bunker vessels. Bunker barges are not self-propelled, requiring tug boats to move them into position, and are designed for use in port areas. By contrast, bunker vessels are selfpropelled, and can be used in open seas. As the American Bureau of Shipping (ABS) notes:

\begin{abstract}
These ships could have a greater LNG delivery range and a larger capacity than barges making them more suitable for bunkering larger LNG fuelled ships or ships in remote ports located far away from natural gas sources. LNG bunker ships are typically designed, constructed, and operated in accordance with the IGC Code and class requirements for LNG carriers. ${ }^{202}$
\end{abstract}

The common element is that the bunkering process requires the bunker barge/vessel to pull alongside the LNG-fuelled vessel, either in port or at anchor, and transfer the LNG fuel. In port, this does not interfere with the dockside loading/unloading activities of the ship that is receiving LNG as a fuel. The amount of LNG that may be transferred depends on the capacity of the bunker vessel, ranging from $100 \mathrm{~m}^{3}$ to $6,500 \mathrm{~m}^{3}$ of LNG (45-2,925 tonnes of LNG, or $58,500-3,802,500 \mathrm{~m}^{3}$ of natural gas). The flow rate of ship-to-ship transfer is approximately $500-1,000 \mathrm{~m}^{3}$ of LNG per hour. ${ }^{203}$

\footnotetext{
198 LNG bunkering practices: truck-to-ship, World Ports Climate Initiative, 2015. http://www.Ingbunkering.org/Ing/ports/Ingbunker-infrastructure. Sourced on 25 June 2018.

${ }^{199}$ According to the International Gas Union (IGU), 1 cubic metre $\left(\mathrm{m}^{3}\right.$ ) of LNG is equal to 0.45 tonnes of LNG or 585 Normal cubic metres $\left(\mathrm{Nm}^{3}\right)$ of natural gas, while 1 tonne of LNG is equal to $2.222 \mathrm{~m}^{3}$ of LNG or $1,300 \mathrm{Nm}^{3}$ of natural gas. Conversely, 1 $\mathrm{Nm}^{3}$ of natural gas is equal to 0.0007692 tonnes or $0.0017 \mathrm{~m}^{3}$ of LNG.

200 Natural gas conversion pocketbook. Oslo: International Gas Union (IGU), 2012. http://agnatural.pt/documentos/ver/naturalgas-conversion-pocketbook fec0aeed1d2e6a84b27445ef096963a7eebab0a2.pdf. Sourced on 25 June 2018. (See page 22.)

${ }^{201}$ Guidance on LNG bunkering to port authorities and administrations, Lisbon: EMSA, 2018, op. cit. (See pages 349-50.)

202 LNG Bunkering: Technical and Operational Advisory, Houston: American Bureau of Shipping (ABS), 2018. (See page 26). https://ww2.eagle.org/content/dam/eagle/advisories-and-debriefs/ABS LNG Bunkering Advisory.pdf.

${ }^{203}$ Guidance on LNG bunkering to port authorities and administrations, Lisbon: EMSA, 2018, op. cit. (See page 50.)
} 

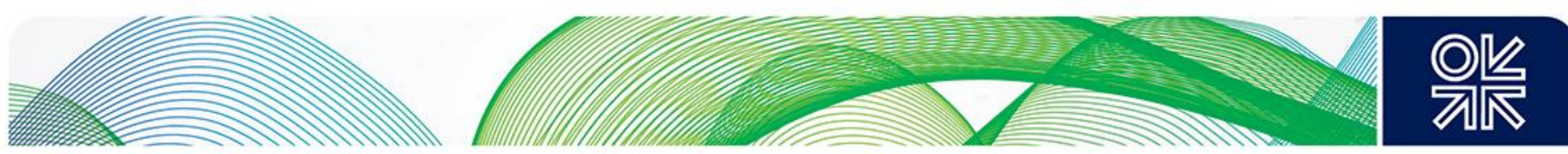

\section{Shore-to-ship - also known as port-to-ship (PTS)}

The bunkering method with the largest storage capacity and highest flow rate is that of 'shore-to-ship', also sometimes referred to as 'port-to-ship' (PTS). This bunkering method requires fixed infrastructure, including an LNG storage tank and loading arm. The advantages of this method are that the larger storage tank enables the bunkering of LNG-propelled vessels that require substantial volumes in a single bunkering session, and the fixed loading arm allows the use of a larger hose, thus enabling a higher flow rate and shorter bunkering times. ${ }^{204}$ According to the European Maritime Safety Agency (EMSA) guidance on LNG bunkering, storage tanks range in capacity from 500 to $20,000 \mathrm{~m}^{3}$ of LNG, while flow rates vary from 1,000 to $2,000 \mathrm{~m}^{3}$ of LNG per hour. ${ }^{205}$ The disadvantage of this method is that ships cannot be bunkered while performing dockside operations. Rather, they must visit fixed bunkering infrastructure at either an LNG import/export terminal, or fixed bunkering infrastructure in the port.

\section{Container-to-ship}

A further method of LNG bunkering, known as 'container-to-ship', involves loading tanks pre-filled with LNG onto the receiving vessel. While this removes the need for LNG transfer using hoses (thus speeding up the bunkering process), it does require the pre-installation of connecting infrastructure in the receiving vessel itself. A further limitation is the size of the LNG tanks that may be loaded onto the vessel. According to EMSA, the capacities of such tanks ranges from 20 to $40 \mathrm{~m}^{3}$ of LNG. 206 This method remains rare, with the overwhelming majority of LNG bunkering being performed using the truck-to-ship, ship-to-ship, and shore-to-ship methods. One example of this 'container-to-ship' method of bunkering is the Honfleur, a ferry ordered by Brittany Ferries in 2016 for delivery in Q2 2019, for operation in the English Channel between Portsmouth (UK) and Ouistreham (France). This method was chosen to overcome the lack of LNG bunkering facilities in Ouistreham. ${ }^{207}$

\footnotetext{
${ }^{204}$ LNG bunkering practices: shore-to-ship, World Ports Climate Initiative (WPCI), 2015. http://www.Ingbunkering.org/lng/ports/Ing-bunker-infrastructure. Sourced on 26 June 2018.

205 Guidance on LNG bunkering to port authorities and administrations, Lisbon: EMSA, 2018, op. cit. (See page 50.) ${ }^{206}$ Guidance on LNG bunkering to port authorities and administrations, Lisbon: EMSA, 2018, op. cit. (See page 51.) 207 'Total, Brittany Ferries, Dunkerque LNG and Groupe Charles André Partner to Supply Liquefied Natural Gas to the First French LNG-Powered Cruise Ferry', Press release, Total, 10 July 2017. https://www.total.com/en/media/news/pressreleases/total-brittany-ferries-dunkerque-Ing-and-groupe-charles-andre-partner-supply-liquefied-natural-gas. Sourced on 18 July 2018.
} 


\section{Appendix 2: Availability of LNG services in the North Sea/Baltic Sea region}

\begin{tabular}{|c|c|c|c|c|c|}
\hline \multicolumn{6}{|c|}{ LNG import terminals } \\
\hline Country & Name & Launch & Bunkering & Truck loading & $\begin{array}{l}\text { Small-scale } L N G \\
\text { reloading }\end{array}$ \\
\hline Belgium & Zeebrugge & 1987 & Yes, ship-to-ship (2017) & $\begin{array}{r}\text { Yes }(2010) \text {, plus } \\
\text { expansion }(2018 / 19)\end{array}$ & Yes (2016) \\
\hline Finland & Pori & 2016 & $\begin{array}{r}\text { Yes, shore-to-ship } \\
(2016)\end{array}$ & Yes (2017) & Yes (2016) \\
\hline \multirow{2}{*}{ Finland } & \multirow{2}{*}{ Tornio Manga } & 2018 & $\begin{array}{r}\text { Under construction } \\
(2018)\end{array}$ & $\begin{array}{r}\text { Under construction } \\
(2018)\end{array}$ & $\begin{array}{r}\text { Under construction } \\
(2018)\end{array}$ \\
\hline & & \multicolumn{4}{|c|}{$\begin{array}{r}\text { First LNG test delivery in November 2017. Launch expected in 'summer 2018'. Since } \\
\text { then, no further confirmation from the project shareholders. }\end{array}$} \\
\hline France & Dunkerque & 2016 & Planned from 2019 & $\begin{array}{r}\text { Planned from end of } \\
2018\end{array}$ & $\begin{array}{r}\text { Yes (2018) } \\
\text { Expansion (2019) }\end{array}$ \\
\hline France & $\begin{array}{l}\text { Montoir-de- } \\
\text { Bretagne* }\end{array}$ & 1980 & - & Yes (Date unknown) & Yes (Date unknown) \\
\hline Lithuania & Klaipeda & 2014 & Yes (2017) & Yes (From 2017) & Yes (From 2017) \\
\hline Netherlands & Gate, Rotterdam & 2011 & $\begin{array}{l}\text { Yes, truck-to-ship } \\
(2013,2015) \text { and } \\
\text { ship-to-ship (2017) }\end{array}$ & Yes $(2014,2017)$ & Yes (2013) \\
\hline Norway & Mosjøen & 2007 & - & Yes (2007) & Yes (2007) \\
\hline Norway & Øra Fredrikstad & 2011 & Yes (2014) & Yes (2011) & Yes (2011) \\
\hline Poland & Swinoujscie & 2016 & Planned from 2021 & Yes (2016) & Planned (2022) \\
\hline Sweden & Nynäshamn & 2011 & - & Yes (2011) & - \\
\hline Sweden & Lysekil & 2014 & Yes, ship-to-ship (2017) & Yes (2014) & Yes (2014) \\
\hline UK & Isle of Grain & 2005 & - & Yes (2015) & - \\
\hline UK & $\begin{array}{l}\text { South Hook* } \\
\text { (Milford Haven) }\end{array}$ & 2009 & - & - & - \\
\hline UK & $\begin{array}{l}\text { Dragon* } \\
\text { (Milford Haven) }\end{array}$ & 2009 & - & - & - \\
\hline & & & wegian LNG export terr & als & \\
\hline Country & Name & Launch & Bunkering & Truck loading & Small-scale reload \\
\hline Norway & Snurrevarden & 2003 & Yes (2004) & - & - \\
\hline Norway & Kollsnes 1 & 2003 & Yes (2003) & - & - \\
\hline Norway & Kollsnes 2 & 2007 & Yes (2007) & - & - \\
\hline Norway & Risavika & 2011 & Yes (2011) & - & - \\
\hline Norway & Snøhvit* & 2007 & Yes (ship-to-ship) & - & - \\
\hline
\end{tabular}

* Outside the ECA, but geographically proximate 

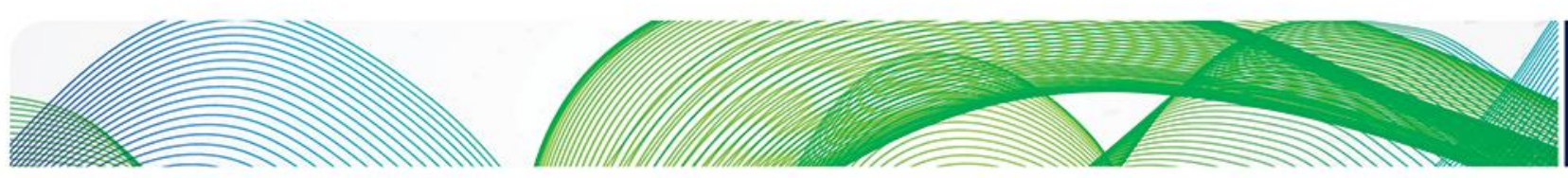

\begin{tabular}{|c|c|c|c|c|}
\hline \multicolumn{5}{|c|}{ Ports with LNG Services } \\
\hline Country & Name & & & Bunkering \\
\hline Belgium & Antwerp & \multicolumn{3}{|c|}{ Yes, truck-to-ship (2013) and shore-to-ship (end of 2019) } \\
\hline Denmark & Hirtshals & \multicolumn{3}{|r|}{ Yes, shore-to-ship (2015) } \\
\hline Denmark & Copenhagen-Malmö & \multicolumn{3}{|r|}{ Yes, truck-to-ship (2018) } \\
\hline Estonia & Tallinn & \multicolumn{3}{|r|}{ Yes, truck-to-ship (2017) } \\
\hline Finland & Helsinki & \multicolumn{3}{|c|}{ Yes, truck-to-ship (2014); bunkership planned (from 2018) } \\
\hline Germany & Brünsbuttel & \multicolumn{3}{|c|}{ Yes, truck-to-ship $(2011,2017)$} \\
\hline Germany & Rostock & \multicolumn{3}{|r|}{ Yes, truck-to-ship (2016) } \\
\hline Germany & Hamburg & \multicolumn{3}{|r|}{ Yes, truck-to-ship (2016) } \\
\hline Germany & Bremen & \multicolumn{3}{|r|}{ Yes, truck-to-ship (2018) } \\
\hline Germany & \multicolumn{4}{|c|}{ Nauticor also performs truck-to-ship LNG bunkering in Emden and Cuxhaven } \\
\hline Netherlands & Amsterdam & \multicolumn{3}{|c|}{ Yes, truck-to-ship (2013); bunkership planned (Date unknown) } \\
\hline Netherlands & Moerdijk & & & Yes (2014) \\
\hline Norway & Florø & & & Yes (2003) \\
\hline Norway & Haugesund & \multicolumn{3}{|r|}{ Yes, ship-to-ship (2004) } \\
\hline Norway & Ågotnes & \multicolumn{3}{|r|}{ Yes, ship-to-ship (2004) } \\
\hline Norway & Avaldsnes & & & Yes (2004) \\
\hline Norway & Bergen & \multicolumn{3}{|r|}{ Yes, ship-to-ship (2009) } \\
\hline Norway & Hordvikneset & & & Yes (2009) \\
\hline Norway & Stavanger & & & Yes (2011) \\
\hline Norway & Haukås & & & Yes (2012) \\
\hline Norway & Melkøya island, Hammerfest* & & & Yes (2017) \\
\hline \multicolumn{5}{|c|}{$\begin{array}{l}\text { Bunkering is also available at the Norwegian port of } \varnothing \text { s in the ECA and at the ports of Bodo, Kirkenes, Kristiansund, } \\
\text { Lødingen, Moskenes, and Sandnessjøen beyond the ECA, but the launch dates are not confirmed }{ }^{*}\end{array}$} \\
\hline \multicolumn{5}{|c|}{ Skangas has been bunkering vessels in international waters since September 2017, using its bunker vessel Coralius. } \\
\hline Sweden & Stockholm & \multicolumn{3}{|c|}{ Yes, ship-to-ship (2012-13) } \\
\hline Sweden & Gothenburg & \multicolumn{3}{|c|}{ Yes, ship-to-ship (2017); Shore-to-ship (2018) } \\
\hline UK & Immingham & Truck-to-ship (2017) & No truck loading & $\begin{array}{l}\text { No small-scale LNG } \\
\text { reloading. }\end{array}$ \\
\hline
\end{tabular}

* Outside the ECA, but geographically proximate

\begin{tabular}{|c|c|c|c|c|c|}
\hline \multicolumn{6}{|c|}{ Facilities under construction, with planned launch dates } \\
\hline Country & Name & Launch & Bunkering & Truck loading & Small-scale reload \\
\hline Denmark & $\begin{array}{l}\text { Port of } \\
\text { Frederikshavn }\end{array}$ & - & $\begin{array}{r}\text { Under Construction } \\
\text { (End of 2018) }\end{array}$ & - & - \\
\hline \multirow{2}{*}{ Finland } & \multirow{2}{*}{$\begin{array}{l}\text { Hamina (Kotka) } \\
\text { LNG Terminal }\end{array}$} & - & $\begin{array}{r}\text { Under Construction } \\
(2020)\end{array}$ & $\begin{array}{r}\text { Under Construction } \\
(2020)\end{array}$ & $\begin{array}{r}\text { Under Construction } \\
(2020)\end{array}$ \\
\hline & & \multicolumn{4}{|c|}{$\begin{array}{r}\text { FID, turnkey construction contract, and permits all in place by May } 2018 \\
\text { Ground-breaking ceremony in September } 2018\end{array}$} \\
\hline Russia & $\begin{array}{l}\text { Kaliningrad } \\
\text { FSRU }\end{array}$ & $\begin{array}{r}\text { Dec } 2018 \\
\text { (tbc) }\end{array}$ & - & - & - \\
\hline
\end{tabular}



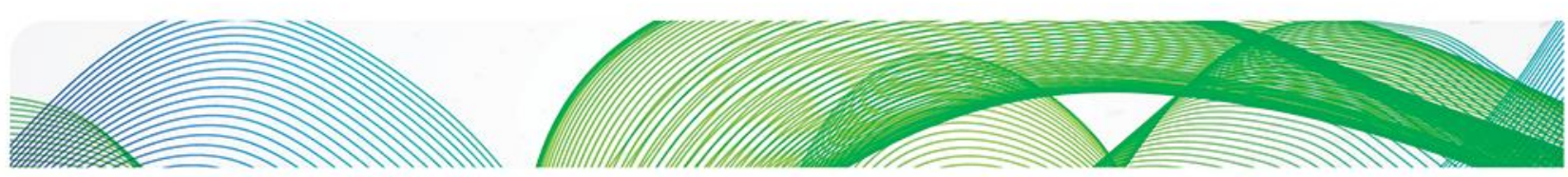

\begin{tabular}{|c|c|c|c|c|c|}
\hline \multicolumn{6}{|c|}{ Planned facilities } \\
\hline Country & Name & Launch & Bunkering & Truck loading & Small-scale reload \\
\hline Estonia & $\begin{array}{l}\text { Muuga (Tallinn) } \\
\text { LNG Terminal }\end{array}$ & - & Planned (unknown) & - & - \\
\hline Estonia & $\begin{array}{l}\text { Paldiski LNG } \\
\text { Terminal }\end{array}$ & - & Planned (unknown) & - & - \\
\hline Finland & $\begin{array}{l}\text { Rauma LNG } \\
\text { Terminal }\end{array}$ & - & Planned (unknown) & - & - \\
\hline Finland & Port of Turku & - & Planned (unknown) & - & - \\
\hline Germany & Port of Cologne & - & Planned (unknown) & - & - \\
\hline Germany & Port of Lübeck & - & Planned (unknown) & - & - \\
\hline Russia & $\begin{array}{l}\text { Gorskaya LNG } \\
\text { (St Petersburg) }\end{array}$ & - & Planned (unknown) & - & - \\
\hline Sweden & $\begin{array}{l}\text { Gävle LNG } \\
\text { Terminal }\end{array}$ & - & - & - & - \\
\hline Sweden & $\begin{array}{l}\text { Port of } \\
\text { Helsingborg }\end{array}$ & - & Planned (unknown) & - & - \\
\hline Sweden & Port of Sundsvall & - & Planned (unknown) & - & - \\
\hline Sweden & Port of Trelleborg & - & Planned (unknown) & - & - \\
\hline UK & $\begin{array}{l}\text { Teesside LNG } \\
\text { (Middlesborough) }\end{array}$ & - & Planned (unknown) & - & - \\
\hline
\end{tabular}

* Outside the ECA, but geographically proximate

Sources:

1 LNG map 2018, Gas Infrastructure Europe (GIE), 2017.

https://www.gie.eu/download/maps/2017/GIE LNG 2018 A0 1189x841 FULL.pdf. Sourced on 13 July 2018.

2 Small-scale LNG map 2018, GIE, 2018. https://www.gie.eu/index.php/gie-publications/maps-data/gle-sslngmap. Sourced on 13 July June 2018.

3 In addition to data from GIE, information has been gathered from other sources. 

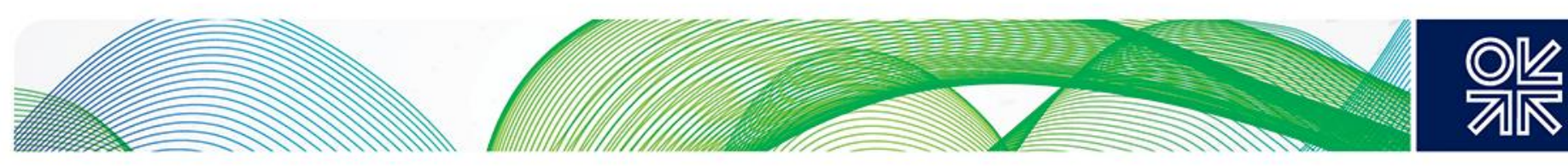

\section{Appendix 3: Engines in LNG-Fuelled Vessels}

It should be noted that vessels running on LNG may have one of several engine types. The data from DNV GL refers to dual fuel, pure LNG, pure gas + diesel, and dual fuel turbine. These engine types operate on one of two combustion cycles: Diesel Cycle (high-pressure, with compression or pilot fuel ignition) or Otto Cycle (low-pressure, with either spark ignition or pilot fuel ignition):

There is a choice to be made initially on the basis of gas combustion principles: The Diesel cycle, used for all diesel two strokes, where air in the cylinder is compressed to beyond fuel ignition point before both gas and pilot fuel are injected at high pressure; or the Otto (or lean-burn) cycle, where gas and air are mixed during compression and ignited by the injection of pilot fuel. That choice has a major impact on three key factors: temperature of combustion (and therefore NOx formation); pressure of gas injection (affecting the cost and complexity of components and the potential for methane slip); and engine performance (with differing maximum compression pressure and thermal efficiency). ${ }^{208}$

A pure gas engine only operates on LNG, according to the Otto Cycle. Because of the risk of uncontrolled ignition (or 'knocking') of the gas-air mixture at high pressure, Otto Cycle engines operate at a relatively low pressure. With no option for a small injection of oil-based pilot fuel (Heavy Fuel Oil [HFO] or Marine Diesel Oil [MDO]), this engine relies on spark ignition.

By contrast, the phrase pure gas + diese/ refers to an engine running with gas as its primary fuel, but with oil-based pilot fuel, on either the Otto or Diesel Cycles. In the Otto Cycle, the low-pressure mixture of compressed air and gas is ignited by the injection of a small amount of pilot fuel. In the Diesel Cycle, compressed air is ignited by the injection of gas and the pilot fuel. Because the air in the compression chamber is compressed before the fuel (LNG) and pilot fuel (diesel) are injected, there is no risk of temperature-induced uncontrolled combustion of gas in the compression chamber. This allows Diesel Cycle engines to operate at a higher pressure than Otto Cycle engines.

Dual fuel turbine engines burn gas or an oil-based fuel (the dual fuels) to generate steam, which turns a turbine to generate power.

The most popular engine type is dual fuel. As the name suggests, these are capable of running on either LNG or an oil-based alternative, giving the flexibility to switch between them. When in 'gas mode', these engines may run on the Otto or Diesel Cycle. For example:

- The low-pressure X-DF engines developed by Winterthur Gas \& Diesel (WinGD) operate on a low-pressure Otto Cycle (when in gas mode), with the air/gas mixture ignited by a small amount of pilot fuel.

- $\quad$ Conversely, the M-type, Electronically Controlled Gas Injection (MEGI) engine developed by MAN Energy Solutions (formerly MAN Diesel and Turbo) operates on the high-pressure Diesel Cycle: The gas and pilot fuel are injected at the same time into a high-pressure combustion chamber. These MEGI engines 'can combust any ratio of natural gas and HFO/MDO' (Heavy Fuel Oil/Marine Diesel Oil). ${ }^{209}$ In other words, the dual fuel MEGI engines may run almost entirely on gas (with only a small amount of HFO or MDO as pilot fuel), entirely on HFO/MDO, or on a mixture of gas and oil-based fuel.

See also: Le Fevre, 2014. The Prospects for Natural Gas as a Transportation Fuel in Europe. Oxford Institute for Energy Studies. https://www.oxfordenergy.org/publications/the-prospects-for-natural-gasas-a-transportation-fuel-in-europe/

\footnotetext{
208 'Dual-fuel two stroke technology advances'. News, Motorship. 24 August 2016. https://www.motorship.com/gfsconference/latest-news101/dual-fuel-two-stroke-technology-advances. Sourced on 11 December 2018.

${ }^{209}$ 2-stroke propulsion, Flex LNG, 2018. https://www.flexlng.com/2-stroke-propulsion/. Sourced on 11 December 2018.
} 


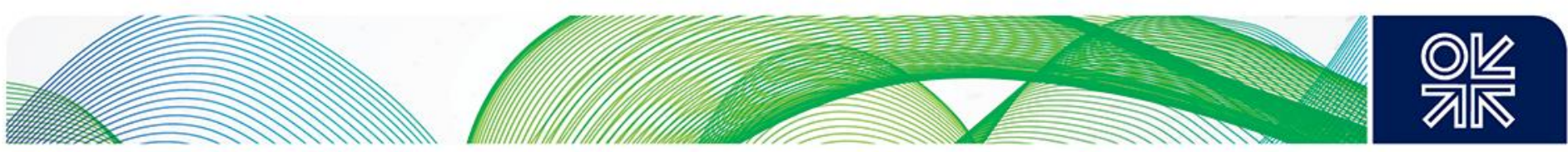

